\title{
Geochemical properties of rocks and soils in Gusev Crater, Mars: Results of the Alpha Particle X-Ray Spectrometer from Cumberland Ridge to Home Plate
}

\author{
D. W. Ming, ${ }^{1}$ R. Gellert, ${ }^{2}$ R. V. Morris, ${ }^{1}$ R. E. Arvidson, ${ }^{3}$ J. Brückner ${ }^{4}$ B. C. Clark, ${ }^{5}$ \\ B. A. Cohen, ${ }^{6}$ C. d'Uston, ${ }^{7}$ T. Economou, ${ }^{8}$ I. Fleischer, ${ }^{9}$ G. Klingelhöfer, ${ }^{9}$ T. J. McCoy, ${ }^{10}$ \\ D. W. Mittlefehldt, ${ }^{1}$ M. E. Schmidt, ${ }^{10}$ C. Schröder, ${ }^{1}$ S. W. Squyres, ${ }^{11}$ E. Tréguier, ${ }^{7}$
}

A. S. Yen, ${ }^{12}$ and J. Zipfel ${ }^{13}$

Received 18 May 2008; revised 4 September 2008; accepted 10 October 2008; published 19 December 2008.

[1] Geochemical diversity of rocks and soils has been discovered by the Alpha Particle X-Ray Spectrometer (APXS) during Spirit's journey over Husband Hill and down into the Inner Basin from sol 470 to 1368 . The APXS continues to operate nominally with no changes in calibration or spectral degradation over the course of the mission. Germanium has been added to the Spirit APXS data set with the confirmation that it occurs at elevated levels in many rocks and soils around Home Plate. Twelve new rock classes and two new soil classes have been identified at the Spirit landing site since sol 470 on the basis of the diversity in APXS geochemistry. The new rock classes are Irvine (alkaline basalt), Independence (low Fe outcrop), Descartes (outcrop similar to Independence with higher $\mathrm{Fe}$ and $\mathrm{Mn}$ ), Algonquin (mafic-ultramafic igneous sequence), Barnhill (volcaniclastic sediments enriched in $\mathrm{Zn}, \mathrm{Cl}$, and Ge), Fuzzy Smith (high Si and Ti rock), Elizabeth Mahon (high Si, Ni, and Zn outcrop and rock), Halley (hematite-rich outcrop and rock), Montalva (high K, hematite-rich rock), Everett (high Mg, magnetite-rich rock), Good Question (high Si, low Mn rock), and Torquas (high K, Zn, and Ni magnetite-rich rock). New soil classes are Gertrude Weise (very high Si soil) and Eileen Dean (high $\mathrm{Mg}$, magnetite-rich soil). Aqueous processes have played a major role in the formation and alteration of rocks and soils on Husband Hill and in the Inner Basin.

Citation: Ming, D. W., et al. (2008), Geochemical properties of rocks and soils in Gusev Crater, Mars: Results of the Alpha Particle X-Ray Spectrometer from Cumberland Ridge to Home Plate, J. Geophys. Res., 113, E12S39, doi:10.1029/2008JE003195.

\section{Introduction}

[2] The Mars Exploration Rover Spirit landed in Gusev Crater on 4 January 2004 [Squyres et al., 2004]. Since then

\footnotetext{
${ }^{1}$ NASA Johnson Space Center, Houston, Texas, USA.

${ }^{2}$ Department of Physics, University of Guelph, Guelph, Ontario, Canada.

${ }^{3}$ Department of Earth and Planetary Sciences, Washington University, St. Louis, Missouri, USA.

${ }^{4}$ Max-Planck-Institut für Chemie, Mainz, Germany.

${ }^{5}$ Space Science Institute, Boulder, Colorado, USA.

${ }^{6}$ NASA Marshall Space Flight Center, Huntsville, Alabama, USA.

${ }^{7}$ Centre d'Etude Spatiale des Rayonnements, OMP, Université Paul Sabatier, CNRS, Toulouse, France.

${ }^{8}$ Enrico Fermi Institute, University of Chicago, Chicago, Illinois, USA.

${ }^{9}$ Institut fur Anorganische und Analytische Chemie, Johannes Gutenberg Universität, Mainz, Germany.

${ }^{10}$ Department of Mineral Sciences, Smithsonian Institution, Washington, D.C., USA.

${ }^{11}$ Department of Astronomy, Cornell University, Ithaca, New York, USA.

${ }^{12}$ Jet Propulsion Laboratory, California Institute of Technology, Pasadena, California, USA.

${ }^{13}$ Forschungsinstitut und Naturmuseum Senckenberg, Frankfurt, Germany.
}

Copyright 2008 by the American Geophysical Union. 0148-0227/08/2008JE003195\$09.00
Spirit successfully traversed the Gusev Crater plains, ascended to the top of Husband Hill, and entered into the Inner Basin of the Columbia Hills. The Athena science payload onboard Spirit recorded numerous measurements on the chemistry and mineralogy of materials encountered during nearly two Mars years of operation within the crater. Rocks and soils are grouped into classes based upon unique differences in chemistry [Squyres et al., 2006; Ming et al., 2006; Morris et al., 2006]. Significant chemical discoveries include the composition of Adirondack Class basalts [Gellert et al., 2004; McSween et al., 2004, 2006a]; high sulfur in Clovis and Peace Class rocks [Gellert et al., 2006; Ming et al., 2006]; high $\mathrm{P}$ and Ti in Wishstone Class rocks [Gellert et al., 2006; Ming et al., 2006]; composition of alkalic basalts [Ming et al., 2006; McSween et al., 2006b]; very high $\mathrm{S}$ in Paso Robles Class soils [Gellert et al., 2006; Ming et al., 2006], and the possible occurrence of a smectite-like phase in the Independence Class rocks [Clark et al., 2007]. Key mineralogical discoveries are occurrences of goethite in Clovis Class rocks, hematite in Clovis, Wishstone, and Watchtower Class rocks, ferric sulfate in Paso Robles soils [Morris et al., 2006], and opaline silica in Gertrude Weise soil and nodule-like outcrops [Squyres et al., 2008]. Mössbauer spectrometer $\mathrm{Fe}^{3+} / \mathrm{Fe}_{\mathrm{T}}$ indicate that Adirondack Class basalts 
are relatively unaltered materials; Clovis and Watchtower Class rocks and outcrops are pervasively altered materials. For a synopsis of operations and measurements from landing through sol 512 see Arvidson et al. [2006] and from sol 513 to sol 1368 see Arvidson et al. [2008].

[3] Water has played a significant role in the alteration of rocks and soils in the Columbia Hills. The occurrence of goethite and ferric sulfate is sufficient to suggest that liquid water was involved in their formation [Morris et al., 2006]. The pervasively altered materials in Husband Hill outcrops and rocks may have formed by aqueous alteration of basaltic rocks, volcaniclastic materials, and/or impact ejecta by solutions that were rich in acid volatile elements [Ming et al., 2006]. Acid fog alteration of Martian basalt is a plausible mechanism for formation of the altered rocks in the Columbia Hills [Tréguier et al., 2008].

[4] Gellert et al. [2006] provided an overview on the health and calibration of the Alpha Particle X-Ray Spectrometer (APXS) and the geochemical data set for the first 470 sols of Spirit's mission. The main objective of this paper is to provide an update on the status of the APXS instrument and to expand the geochemical data set from sols 470 to 1368 . Specific objectives are to 1) provide an update to the rock and soil classification systems to include all rocks and soils up to sol 1368,2 ) characterize elemental relationships among major rock and soil classes, and 3) evaluate the involvement of water in formation or alteration of the materials in these classes.

\section{Geologic Setting and Sampling Areas}

[5] Spirit landed on the Hesperian aged volcanic plains of the Noachian age, $160 \mathrm{~km}$ diameter Gusev Crater at $14.5692^{\circ} \mathrm{S}, 175.4729^{\circ} \mathrm{E}$ in International Astronomical Union 2000 coordinates [Squyres et al., 2004; Arvidson et al., 2004]. The landing site was located about $2.7 \mathrm{~km}$ to the NW of the Columbia Hills. Spirit traversed over the plains toward the Columbia Hills, over the West Spur, and up Husband Hill during the first 470 sols of the mission (see Arvidson et al. [2006] for details of the first 512 sols and Arvidson et al. [2008] for the remaining sols). Around sol 470 Spirit was conducting a series of geochemical, mineralogical, and morphological measurements on an outcrop called Methuselah on Cumberland Ridge of Husband Hill (see Figure 1). The rover ascended to the top of Husband Hill (summit) and then descended via Haskin Ridge into the Inner Basin (Figure 1). Once in the Inner Basin Spirit drove by several layered structures (Seminole and Comanche) and the El Dorado ripple field on its way to Home Plate. Spirit has spent a considerable amount of time in the general vicinity of Home Plate (sols 752 to 1368 , which are covered in this paper, and beyond). Descriptions of the various features are described elsewhere [Arvidson et al., 2008].

[6] The Columbia Hills formed by uplift related either to formation of the Gusev Crater central peak or through mutual interference of overlapping crater rims within Gusev Crater [McCoy et al., 2008]. There is no evidence that Spirit directly encountered any uplifted materials; rather, the materials that cover Husband Hill are draped over the hills by later impact and/or volcaniclastic events. The source of these materials is not clear; however, there are many nearby young craters that could have contributed impact ejecta [Cohen, 2006], and there appears to have been volcanic activity associated with the formation of Home Plate in the nearby Inner Basin [Squyres et al., 2007]. The Inner Basin contains several interesting features that likely have formed by volcanic processes. Home Plate is an $80 \mathrm{~m}$ wide quasi-circular feature that consists of several strata of clastic materials and the lower strata appear to have been emplaced during an explosive volcanic event. The upper strata at Home Plate appear to be pyroclastic materials reworked by eolian processes.

[7] Feature and target names for the APXS measurements along with the sol measurement, type of material analyzed, and general sampling location are listed in Table 1 (Table 1 is a list of oxide wt $\%$ and Table 2 is a list of standard errors for each measurement). The feature name refers to a rock, outcrop, or small areographic area and the target name is the location on or within the feature where the APXS was placed for measurement. A designation "Awxyz_BC Feature_Target" was used to define the sol, material, sample preparation, feature, and target where A is Spirit, wxyz is sol number, B is R (float rock), S (soil), O (outcrop), D (dune) or $\mathrm{C}$ (clod), $\mathrm{C}$ is $\mathrm{U}$ (undisturbed surface), B (RAT brush), or $\mathrm{S}$ (scuffed with wheel). Operation of the Rock Abrasion Tool (RAT) was restricted to only brushing sample surfaces after sol 420 [Arvidson et al., 2006]. The measurements are listed in the order they were acquired by Spirit's APXS and will be discussed in detail in sections 6 and 7.

\section{APXS Instrument Health and Calibrations}

\subsection{Instrument Health}

[8] The energy resolution of the $\mathrm{X}$ ray detector has remained constant over the nearly four Earth years of operation. Neither degradation of FWHM or additional peak tailing are visible in the spectra. The FWHM remains $\sim 165 \mathrm{eV}$ at the $6.4 \mathrm{keV}$ iron $\mathrm{K}_{\alpha}$ peak for temperatures below $\sim-50^{\circ} \mathrm{C}$ during the night. The overall performance of the APXS however has actually improved over the course of the mission because the close-by ${ }^{57} \mathrm{Co}$ Mössbauer source has lost most of its original strength. The background above $6 \mathrm{keV}$ has decreased by a factor of $\sim 2.5$ since the beginning of the mission, significantly enhancing the capability to measure high $\mathrm{Z}$ trace elements, i.e., $\mathrm{Ni}, \mathrm{Zn}$, $\mathrm{Br}$, and Ge (see section 4).

\subsection{Constancy of the Calibration}

[9] The calibration procedure used for deriving chemical compositions from APXS data is discussed by Gellert et al. [2006]. The APXS instrument is sensitive to dust contamination on the $\mathrm{X}$ ray detector as well as on the ${ }^{244} \mathrm{Cm} \mathrm{X}$-ray sources. The $\mathrm{X}$ ray detector chip is sealed in a compartment with a $5 \mu \mathrm{m}$ Be window for transmission of the X rays. The seal was damaged on the Opportunity APXS, releasing the 1 bar $\mathrm{N}_{2}$ atmosphere and changing the calibration for the Opportunity APXS (R. Gellert et al., In situ chemistry along the traverse of Opportunity at Meridiani Planum: Sulfate rich outcrops, iron rich spherules, global soils and various erratics manuscript in preparation, 2008). We therefore monitored Spirit's APXS carefully for any changes that might suggest a similar breach of the $\mathrm{X}$ ray detector compartment. Typical basaltic Gusev surface soils were used to check for changes in the behavior of the detector. Gusev basaltic surface soil has 


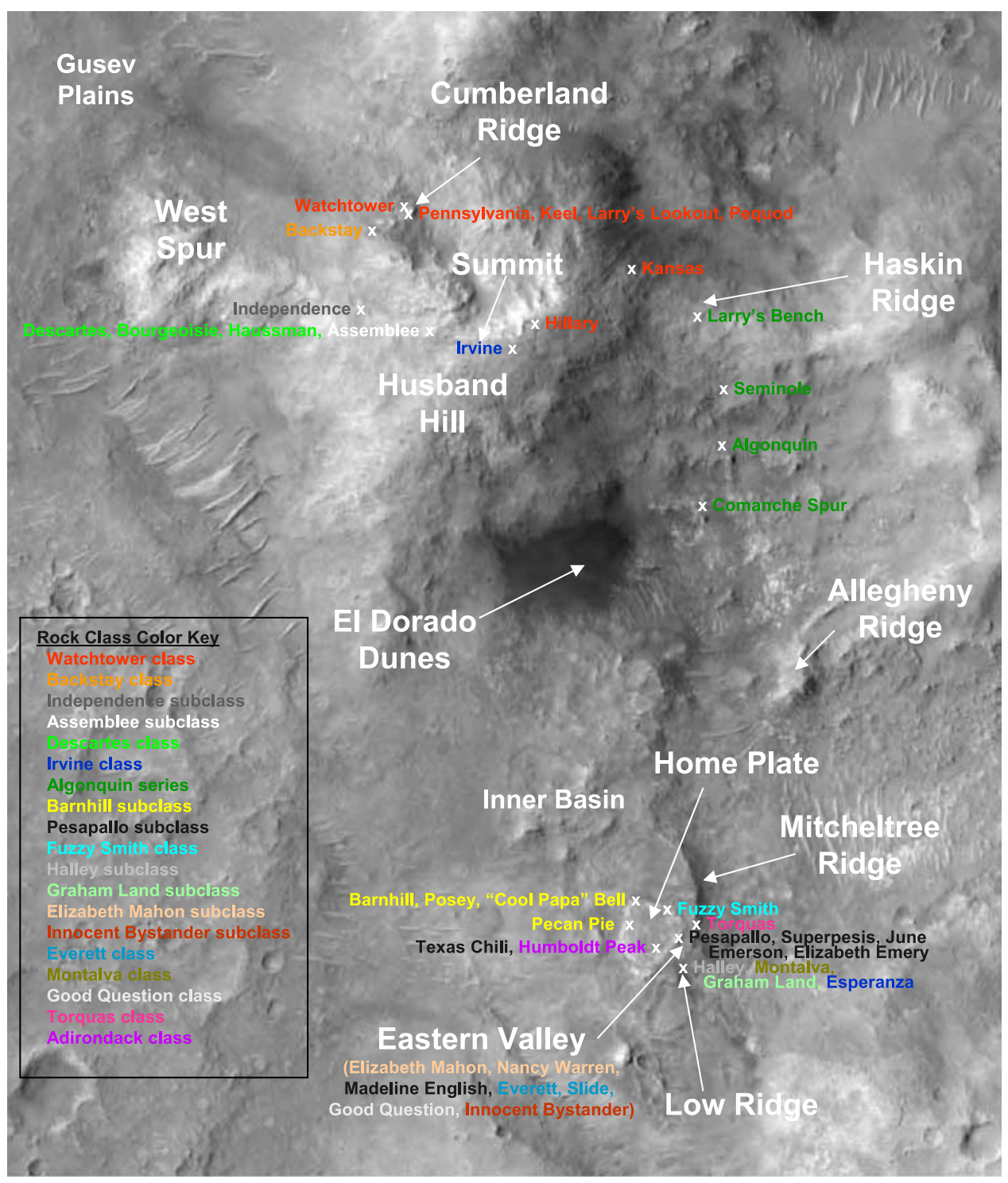

Figure 1. High Resolution Imaging Science Experiment (HiRISE) image of Husband Hill and the Inner Basin taken by the NASA Mars Reconnaissance Orbiter. The approximate locations of Alpha Particle X-Ray Spectrometer (APXS) measurements for rock classes are shown on this image (see color key for rock classes on image). See Arvidson et al. [2008] for detailed descriptions of APXS sampling sites. (HiRISE PSP_001777_1655; image credit University of Arizona, JPL, and NASA.)

been constant in chemical composition during the entire mission except for a few soils that have signatures of local rocks and the unique high $\mathrm{S}$ or Si soils.

[10] The low-Z elements in surface soils have been very consistent over the traverse (Figure 2a). All soils that have been measured by the Spirit APXS are shown here, even the soils that were obviously very different from a typical Gusev surface soil (i.e., Boroughs, Paso Robles, Arad, and Gertrude Weise, see section 7). Measurements of $\mathrm{Na}$, $\mathrm{Mg}, \mathrm{Al}$, and $\mathrm{Si}$ for these soils with longer than $1 \mathrm{~h}$ acquisition time are normalized to the composition of the very first surface soil measured by Spirit, i.e., Gusev soil on sol 14. The low-Z elements show only minor changes in the element pattern as the mission has progressed, which suggests constant instrument parameters. A measurement made on sol 1230 after the global dust storms of 2007 on a target dubbed Calibration soil showed no significant change in the concentration of the light elements compared to Gusev soil, demonstrating that there has been no contamination of the source or the detector window by dust over the course of the mission.

[11] There is a small decrease in the Na content for increasing standoff distances of the APXS (distance between target surface and detector). This $\mathrm{Na}$ decrease results from increased absorption of the low-energy $\mathrm{Na} X$ rays in the Martian atmosphere. The measurement of Gusev soil (sol 14) was made with a relatively large standoff of nearly $2 \mathrm{~cm}$; hence, most other soils have a slightly higher $\mathrm{Na}$ content resulting from closer proximity to the target $(\sim 1 \mathrm{~cm}$ standoff distance). There was a considerably large standoff $(\sim 5 \mathrm{~cm})$ for Marguerite Davis (sol 1235) and the Na content is nearly $10 \%$ lower than typical soil.

[12] The heavier elements (i.e., $\mathrm{K}, \mathrm{Ca}, \mathrm{Ti}$, and $\mathrm{Fe}$ ) in typical Gusev soils have similar ratios as the lighter elements when 


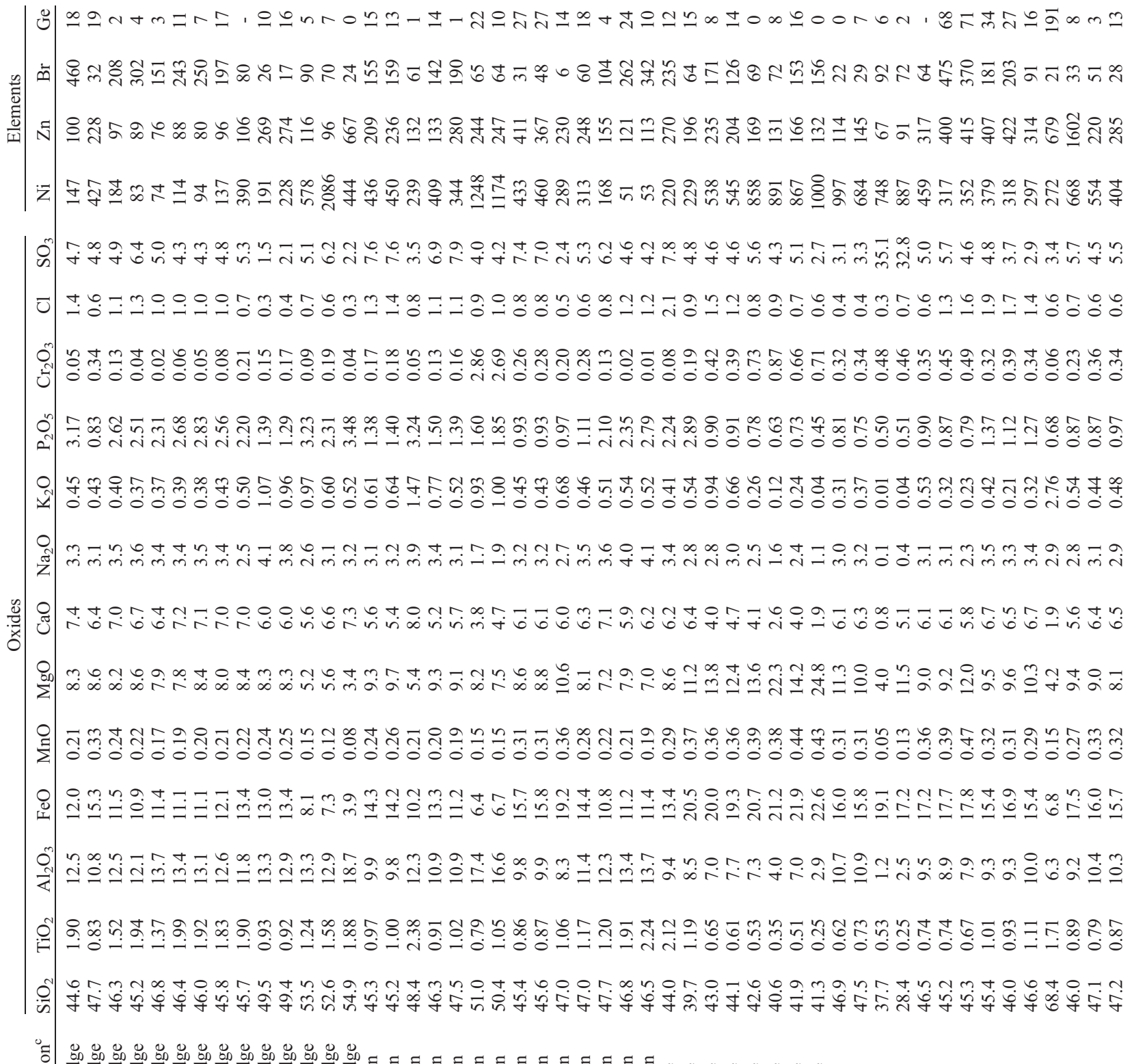

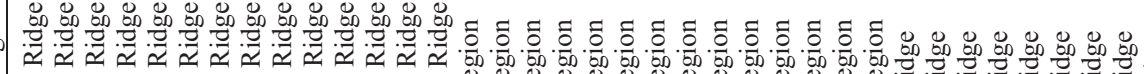

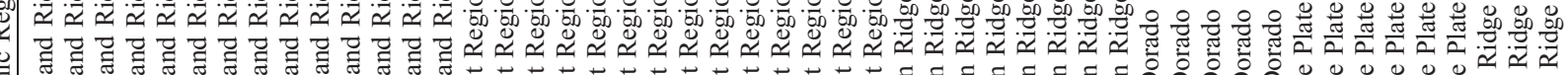

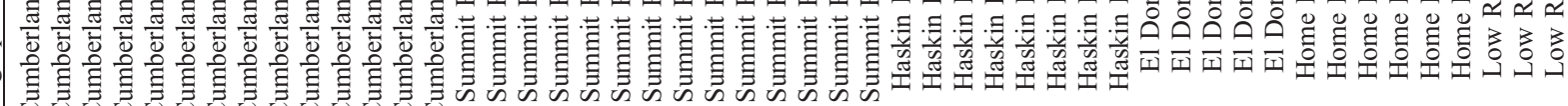

$=\quad$ 总

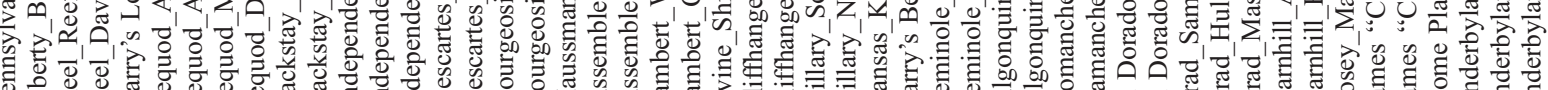

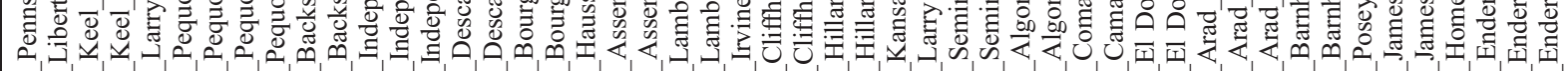

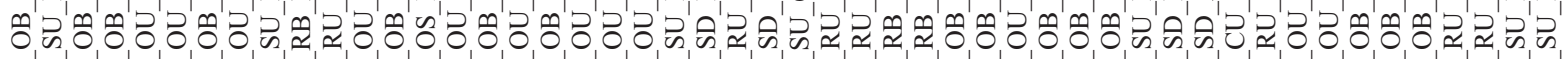

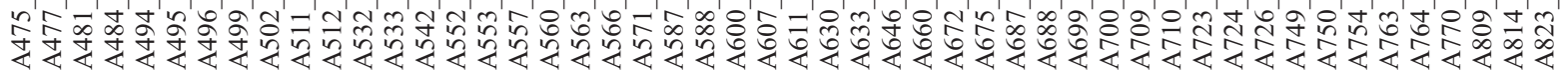


Øூ

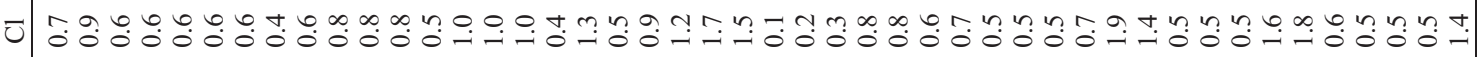

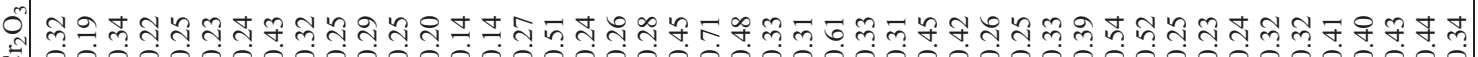

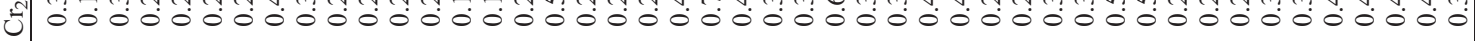

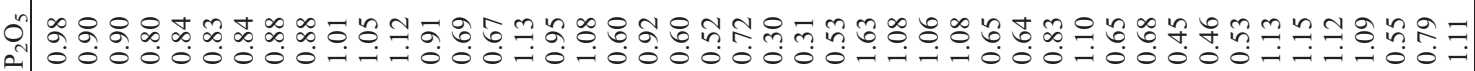

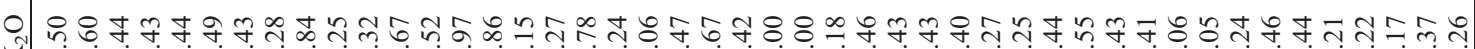

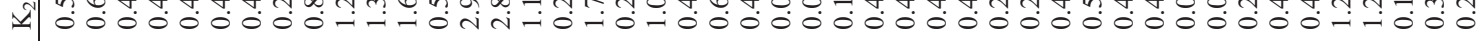

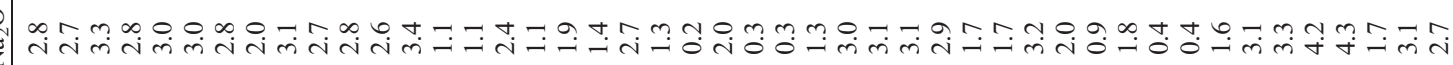

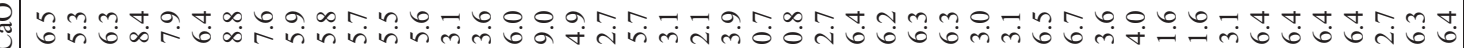

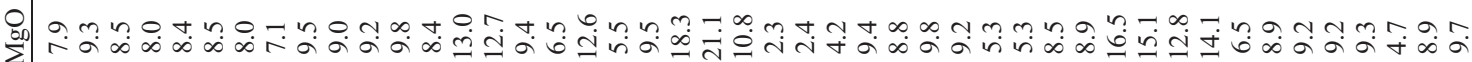

입ำ

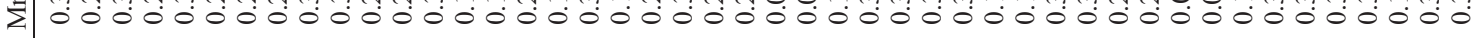

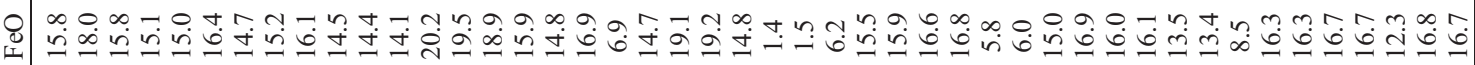

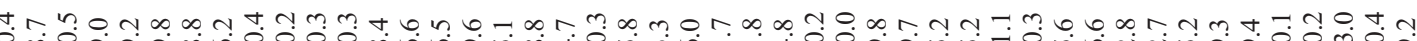

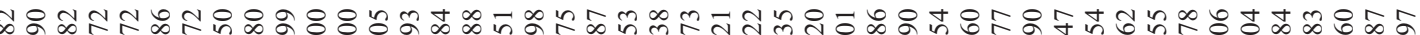

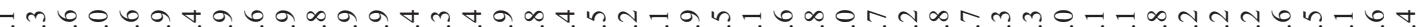

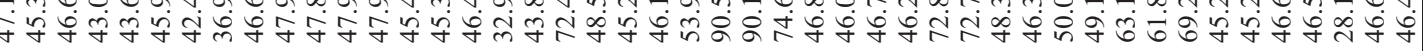

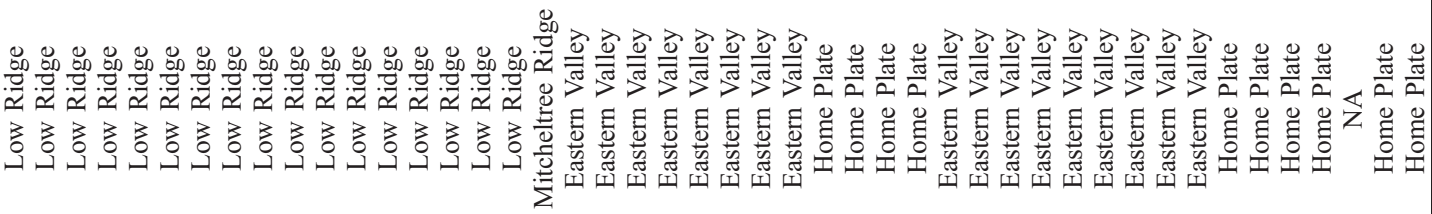

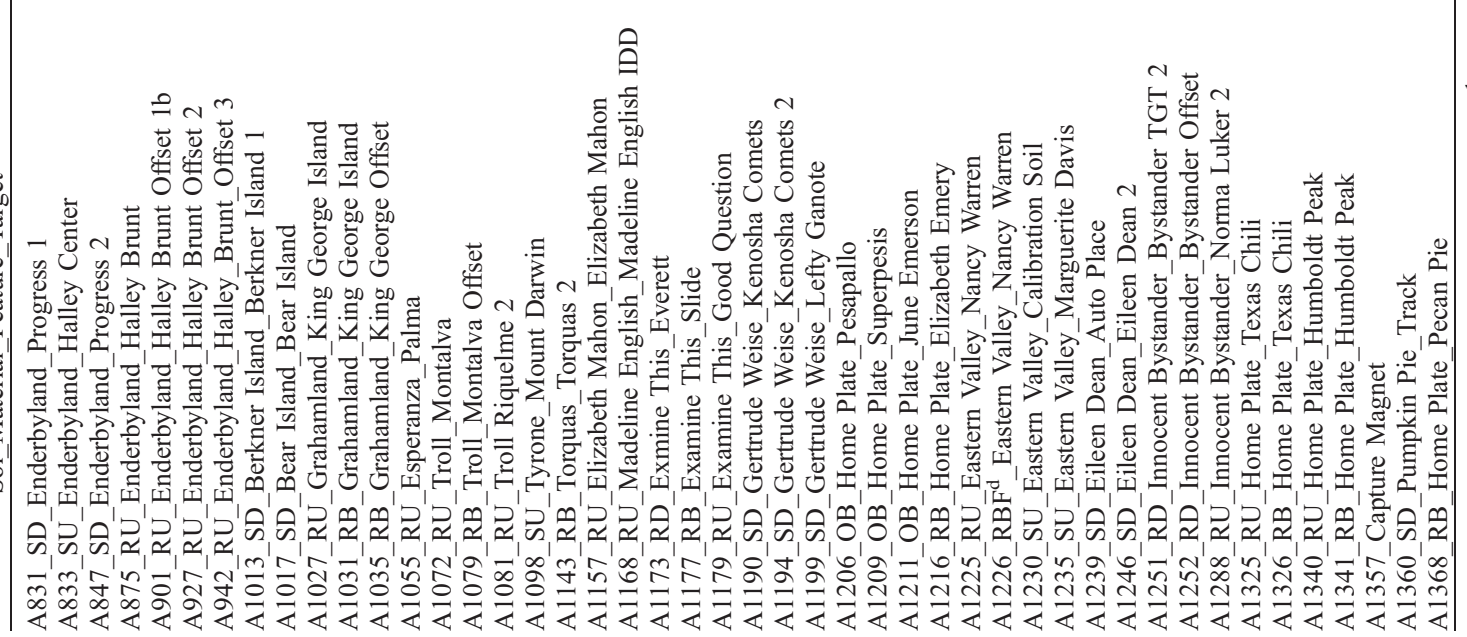

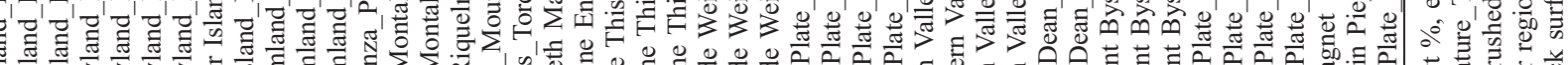

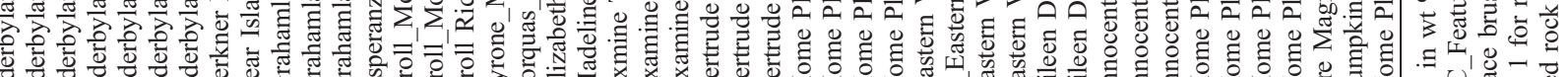

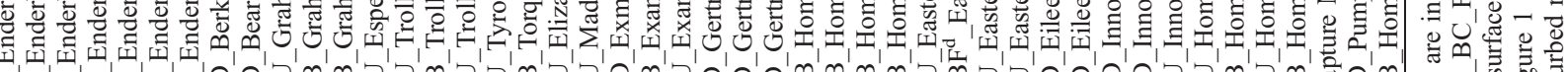

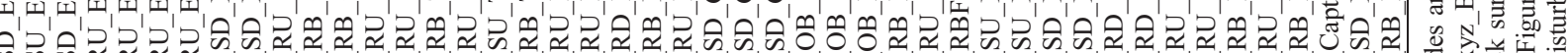

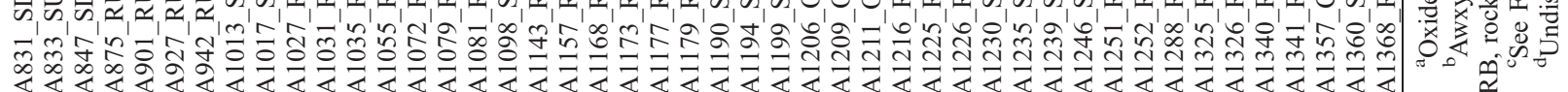


Table 2. Standard Error for Oxide Compositions of All Gusev Crater Samples Determined by the Alpha Particle X-Ray Spectrometer From Sols $471-1368^{\mathrm{a}}$

\begin{tabular}{|c|c|c|c|c|c|c|c|c|c|c|c|c|c|c|c|c|c|}
\hline Sol_Material_Feature_Target ${ }^{\mathrm{b}}$ & $\mathrm{iO}_{2}$ & $\mathrm{iO}_{2}$ & $\mathrm{Al}_{2} \mathrm{O}_{3}$ & $\mathrm{FeO}$ & $\mathrm{MnO}$ & $\mathrm{MgO}$ & $\mathrm{CaO}$ & $\mathrm{Na}_{2} \mathrm{O}$ & $\mathrm{K}_{2} \mathrm{O}$ & $\mathrm{P}_{2} \mathrm{O}_{5}$ & $\mathrm{Cr}_{2} \mathrm{O}_{3}$ & $\mathrm{Cl}$ & $\mathrm{SO}_{3}$ & $\mathrm{Ni}$ & $\mathrm{Zn}$ & $\mathrm{Br}$ & ( \\
\hline 475 OB Pennsylvania RAT-Pitt & 0.4 & 9 & 0.1 & 0.1 & 0.01 & 0.1 & 0.1 & 0.3 & 06 & .11 & 0.03 & .0 & 1 & 47 & 17 & 4 & 12 \\
\hline A477 SU Liberty Bell $\overline{2}$ & .5 & .07 & 0 & 0.1 & 0.01 & 0.2 & 0.1 & 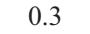 & 0.06 & 0.08 & .03 & 0.0 & 1 & 47 & 16 & 6 & 10 \\
\hline 481_OB_Keel_Reef & .4 & 0.08 & 0.1 & 0.1 & 0.01 & 0 . & 0.1 & 0 . & 0.06 & 0.09 & .03 & 0.0 & .1 & 37 & 10 & 17 & 10 \\
\hline A484- $\mathrm{OB}^{-}$Keel Davis & .4 & 08 & 0.1 & 0.1 & 0.01 & 0.1 & 0.0 & & 6 & 0.09 & .03 & .0 & 0.1 & 32 & 8 & 17 & 10 \\
\hline A494_OU_Larry's Lookout_Paros & 0.4 & 0.07 & 0.2 & 0.1 & 0.01 & 0.1 & 0.0 & 0.2 & 0.06 & 0.09 & 0.03 & 0.0 & 0.1 & 35 & 9 & 17 & 10 \\
\hline A495_OU_Pequod_Ahab & 04 & 0.08 & 0.1 & 0.1 & 0.01 & 0.1 & 0.0 & 02 & 0.06 & 0.09 & 0.03 & 0.0 & 0.1 & 34 & 9 & 17 & 10 \\
\hline A496_OB_Pequod_Ahab & .4 & 0.07 & 0 . & 0.1 & 0.01 & 0 & 0.1 & & 0.06 & 0.09 & 0.03 & 0 & .1 & 4 & 9 & 7 & 10 \\
\hline A499_OU_Pequod_MobyDick & 0.4 & 0.08 & 0.1 & 0.1 & 0.01 & 0.1 & 0.1 & 0 & 0.06 & 0.09 & 0.03 & .0 & 0.1 & 35 & 9 & 17 & 10 \\
\hline A502_SU_Pequod_Doubloon (Tou & 0.7 & 0.27 & 0. & 0.2 & 0.14 & 0.6 & 0.2 & & 0.20 & 0.76 & 0.08 & 1.1 & 0.2 & 148 & 63 & 39 & 10 \\
\hline A511_RB_Backstay_Scuppers & 04 & 0.06 & 0.1 & 0.1 & 0.01 & 0.1 & 0.0 & 0.2 & 0.06 & 0.08 & 0.03 & 0.0 & 0.0 & 34 & 11 & 14 & 10 \\
\hline A512_RU_Backst & 0.4 & 0.07 & 0.1 & 0.1 & 0.01 & 0.1 & 0.0 & & 0.06 & 0.08 & 0.03 & .0 & 0.0 & 36 & 12 & 14 & 10 \\
\hline A532_OU_Inde & .5 & 0.07 & 0. & 0.1 & 0.01 & 0.1 & 0.0 & & 0.06 & 0.10 & 0.03 & .0 & 0.1 & 43 & 10 & 16 & 10 \\
\hline A533- ${ }^{-}{ }^{-}$Indep & 0.5 & 0.08 & 0.2 & 0.1 & 0.01 & 0 . & 0.0 & & 0.06 & 0.09 & 0.03 & .0 & 0.1 & 54 & 8 & 14 & 10 \\
\hline A542_OS_Indepe & 0.5 & 0.08 & 0.2 & 0.0 & 0.00 & 0.1 & 0.1 & & & 0.10 & 0.03 & .0 & 0.0 & 35 & 13 & 13 & 10 \\
\hline $\mathrm{A} 552^{-} \mathrm{OU}^{-} \mathrm{D}$ & 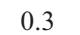 & 0.07 & 0. & 01 & 0.01 & 01 & & & 0.06 & 0.08 & & .0 & .1 & 39 & 10 & 15 & 10 \\
\hline A553_OB_Des & 0.3 & 0.07 & 0 & 0.1 & 0.01 & 0 . & 0 . & & & 0.08 & & 0 & .1 & 99 & 1 & 15 & 10 \\
\hline A557_OU_Bo & 4 & 0.09 & 0 & 0.1 & 001 & 0 . & 01 & & 0.07 & 0.10 & & .0 & 0.1 & 7 & 0 & 15 & 10 \\
\hline A560_OB-Bo & 04 & 0.07 & 0 & 0.1 & 0.01 & 0 & 0.0 & & & 0.08 & & .0 & .1 & 0 & 10 & 16 & 10 \\
\hline A563_OU_Haus & ( & 0.07 & 0. & 0.1 & 0.01 & & & & & 0.08 & & 0 & .1 & 8 & 12 & 16 & 10 \\
\hline $56 \mathrm{OU}^{-} \mathrm{As}$ & 0.3 & 0 & 0 & 0 & 0. & 0 & & & & 0.08 & & .0 & .1 & 7 & 11 & 14 & 7 \\
\hline A571_OU_As & 0.5 & 0.07 & 0. & 01 & & 0 & & & & 0.09 & & 0 & & 8 & 12 & 15 & 10 \\
\hline $\mathrm{A} 587^{-} \mathrm{SU}^{-} \mathrm{Lar}$ & 0.4 & 0.06 & 0. & 0.1 & 0 . & 0. & 0 & & & 0.07 & & 0 & 0.1 & 0 & 14 & 15 & 7 \\
\hline A588_SD_Lan & 04 & 0.06 & 0. & 0.1 & 0.01 & 0 . & 00 & & & 0.07 & & .0 & 0.1 & 9 & 12 & 15 & 7 \\
\hline $0^{-} \mathrm{RU}^{-} \mathrm{Ir}$ & 0.3 & & & 01 & & & & & & & & 0 & & 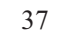 & 11 & 13 & 10 \\
\hline A607_SD_Cli & 0.4 & 0.07 & 0 & 0.1 & $0 .($ & 0 & & & & 0.07 & & 0 & & 6 & 10 & 4 & 10 \\
\hline A611_SU_Cli & & 0.07 & & 0 . & 0 & & & & & 0.08 & & 0 & .1 & 3 & 9 & 15 & 10 \\
\hline A630_RU_Hi & 0 & 0.08 & 0. & 0 . & 0. & & 00 & & & 0.09 & & .0 & 0.1 & 7 & 12 & 18 & 9 \\
\hline A633_RU_Hill & $0 ?$ & 0.08 & & & & & & & & & & .0 & 1 & 3 & 9 & 17 & 10 \\
\hline A646_RB_Kar & & & & 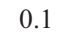 & & & & & & & & 0 & & 5 & 11 & 17 & 10 \\
\hline A660_RB_La & & & & 0 & & & & & & 0.09 & & 0 & & 40 & 13 & 16 & 10 \\
\hline $\mathrm{A} 672^{-} \mathrm{OB}-\overline{\mathrm{Se}}$ & 0. & 0.06 & & 0 . & 0 & & 0.0 & & & 0.07 & & 0 & 0.1 & 13 & 12 & 17 & 10 \\
\hline A675_OB_Semi & 03 & 0.06 & 0 & 01 & 001 & 0 & 00 & & & 0.07 & 3 & .0 & 0.1 & 2 & 11 & 15 & 10 \\
\hline $7^{-} \mathrm{OU}^{-} \mathrm{Al}$ & & & & & & & & & & & & 0 & & 4 & 10 & 15 & 10 \\
\hline 38_OB_Al & 0.3 & 0 & & 0 & $0 .($ & & & & & 0.07 & 3 & 0 & & 3 & 9 & - & 10 \\
\hline $\mathrm{A} 699^{-} \mathrm{OB}^{-} \mathrm{Cc}$ & 03 & 0 & & 0 & & & & & & 0.07 & & .0 & 1 & 46 & 11 & 16 & 10 \\
\hline $\mathrm{A} 700+\mathrm{OB} C \mathrm{Ca}$ & & 0.06 & & 0. & & & & & & & & 0 & 0 & 49 & 11 & 17 & 10 \\
\hline A709_SU_El D & 04 & 0.06 & 0 & 01 & 00 & & & & & & & 0 & & 4 & 0 & 4 & 10 \\
\hline SD_El & & & & & & & & & & & & U & & 0 & 9 & 7 & 10 \\
\hline 3_SD_A & & & & & & & & & & 0.07 & & 0 & & 41 & 8 & 4 & 10 \\
\hline A724_CU_A & & $r$ & & 0 . & & & & & & 0.07 & & 0 & 0.3 & 44 & 9 & 16 & 10 \\
\hline A726_RU_Ara & 06 & 0.10 & 0. & 0.2 & 0.03 & ? & 01 & & 0.08 & 0.11 & 0.06 & .0 & 0.2 & 100 & 48 & 27 & - \\
\hline $\mathrm{A} 749^{-} \mathrm{OU}^{-} \mathrm{Ba}$ & & & & & & & & & & & & 0 & & 35 & 11 & 17 & 6 \\
\hline 0_OU_Ba & & & & & & & & & & & & U & & 9 & 4 & 8 & 8 \\
\hline A754_OB_Po & & 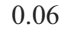 & & 0 & & & & & 0.06 & 0.07 & 5 & .0 & 1 & 35 & 11 & 15 & 5 \\
\hline A763_OB_Jam & 0.3 & 0.06 & 0 & 0.1 & 0.0 & 0 & 0.0 & & 0.05 & 0.07 & 13 & .0 & .0 & 37 & 13 & 16 & 10 \\
\hline A764_OB_James “ & ( & 0.07 & 0 & 0.1 & 0.01 & & & & & & & 0 & 0 & 0 & 14 & 15 & 8 \\
\hline $0 \mathrm{RU}_{-}^{-} \mathrm{Hc}$ & & & & & & & & & & & & U & & 3 & 4 & 3 & 10 \\
\hline 9_RU_En & & & & & & & & & & 0.07 & & 0 & 1 & 40 & 22 & 14 & 10 \\
\hline A814_SU_Enc & & 5 & 0 & 0.1 & 0. & 0 & & & 0.06 & 0.07 & 33 & .0 & 0.1 & 42 & 11 & 15 & 10 \\
\hline A823_SU_Ende & 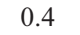 & 0.07 & 0. & 0.1 & 0.01 & 0 . & 0.0 & 0 . & 0.06 & 0.08 & 0.03 & .0 & 0.1 & 46 & 16 & 15 & 10 \\
\hline A $831^{-}$SD $^{-}$Enderbyland ${ }^{-} \mathrm{P}$ & & & & 01 & & & & & & & & 0 & .1 & 51 & 18 & 17 & 10 \\
\hline 3_SU_E & & & & & & & & & & & & r & & 2 & 8 & f & 10 \\
\hline 47_SD_E & & & & & & & & & & 0.07 & & 0 & & 9 & 11 & 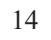 & 10 \\
\hline A875_RU_Ender & .4 & 0.07 & 0 & 0.1 & $0 .($ & 0 & 0.1 & & 0.06 & 0.08 & 3 & .0 & .1 & 44 & 23 & 16 & 10 \\
\hline A901_RU_Ende & & & 0 & 0 & & & & & & & & 0 & .2 & 65 & 40 & 20 & 17 \\
\hline 7_RU_End & & & & 0 & & & & & & & & 0 & & 1 & 0 & 6 & 10 \\
\hline U_E & & & & & & & & & & 0. & & 0 & & 1 & 7 & 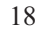 & 10 \\
\hline $1 \overline{3} \mathrm{SD} B$ & 0.4 & 0.07 & 0 & 0. & & 0 & & & & & & .0 & 0.2 & 55 & 16 & 17 & 10 \\
\hline A1017_SD_Bear & 0.5 & 0.07 & 0.1 & 0.1 & 0.01 & 0.1 & 0.1 & 0.3 & 0.06 & 0.08 & 0.03 & .0 & 0.1 & 46 & 16 & 16 & 8 \\
\hline A1027 RU Grahamland̄ King Georg & & & 0. & 01 & & & & & & & & .0 & 0.1 & 4 & 9 & 17 & 9 \\
\hline 31_RB_C & & & & 0 & & & & & & & & 0 & 0.1 & 5 & 1 & & 10 \\
\hline 35_RB_Gr & & & & & & & & & & & & & & 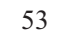 & 0 & 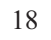 & 9 \\
\hline A1055_RU_Esp & . & 0.08 & 0 . & 0.2 & 0.01 & 0 & 0.1 & 0 & & 0.08 & 0.03 & .0 & 0.1 & 54 & 22 & 23 & 10 \\
\hline A1072_RU_Troll_Montalva & 0.4 & 0.07 & 0 & 0.1 & 0.01 & 0.2 & 0.0 & 0.2 & 0.08 & 0.07 & 0.03 & 0.0 & 0.1 & 54 & 22 & 16 & 10 \\
\hline A1079_RB_Tro & & 0.07 & & 0 . & 0. & & & & & 0.08 & 002 & 0 & 1 & 5 & 2 & 0 & 10 \\
\hline 1_RU_Tr & & & & & & & & & & & & 0 & 0.1 & 9 & & & 10 \\
\hline 98_SU_Tyro & & & 0 . & & & & & & & & & .0 & .3 & 78 & 28 & 21 & 10 \\
\hline A1143_RB_Torql & 0.3 & 0.07 & 0.1 & 0.1 & 0.01 & 0.1 & 0.1 & 0.2 & 0.08 & 0.08 & 0.03 & 0.0 & 0.1 & 77 & 40 & 21 & 12 \\
\hline A1157 RU É-Eliz & 0.5 & 0.06 & 0 . & 0 & 0.0 & 0 . & 0 . & 0 . & 0.06 & 0.07 & 0.03 & 0.0 & 0.1 & 51 & 18 & 4 & 6 \\
\hline A1168_RU_Madeline English_Madeline & 0.4 & 0.06 & 0.1 & 0.1 & 0.01 & 0.1 & 0.0 & 0.3 & 0.06 & 0.07 & 0.03 & 0.0 & 0.1 & 41 & 16 & 15 & 7 \\
\hline
\end{tabular}


Table 2. (continued)

\begin{tabular}{|c|c|c|c|c|c|c|c|c|c|c|c|c|c|c|c|c|c|}
\hline $\mathrm{t}^{\mathrm{b}}$ & $\mathrm{iiO}_{2}$ & $\mathrm{~T}$ & $\mathrm{Al}_{2} \mathrm{C}$ & - & $\mathrm{MnO}$ & $\operatorname{lgO}$ & $\mathrm{CaO}$ & $\mathrm{Na}_{2} \mathrm{O}$ & $\mathrm{K}_{2} \mathrm{O}$ & $\mathrm{P}_{2} \mathrm{O}_{5}$ & $\mathrm{Cr}_{2} \mathrm{O}_{3}$ & $\mathrm{Cl}$ & $\mathrm{SO}_{3}$ & $\mathrm{Ni}$ & $\mathrm{Zn}$ & B & $\mathrm{Ge}$ \\
\hline 110_1 & & & & & & & 0 & & & & & 0.0 & 0 & 5 & 0 & 10 & \\
\hline 7_RB_F & & & & & & & & & & & & 0 & 0 & 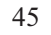 & 2 & 7 & \\
\hline $79^{-} \mathrm{RU}^{-} \mathrm{E}$ & & & & & & & & & & .07 & & .0 & & 0 & 3 & 8 & 10 \\
\hline 0_SD_G & & & & & & & & & & & & & & 1 & & & 10 \\
\hline $4^{-} \mathrm{SD}^{-} \mathrm{G}$ & & & & & & & & & & & & & & 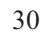 & 9 & & 10 \\
\hline 99_SD_C & & & & & & & & & & & & .0 & .1 & 3 & 23 & 10 & 10 \\
\hline $206^{-} \mathrm{OB}^{-} \mathrm{H}$ & & & & & & & & & & & & .0 & & & 21 & 16 & \\
\hline $\mathrm{OB}_{-}^{-}$ & & & & & & & & & & & & 0 & & & 5 & & \\
\hline${ }^{-} \mathrm{OB}-1$ & & & & & & & & & & & & & & & & & \\
\hline$-\mathrm{D}$ & & & & & & & & & & & & & & & 6 & & \\
\hline $\mathrm{D}$ & & 0 & 0 & & & & 0 & & & 0.07 & & 0.0 & 0.1 & 4 & 10 & 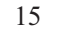 & 10 \\
\hline$\overline{F^{2}}$ & & & & & & & & & & & & .0 & & & 11 & & 10 \\
\hline 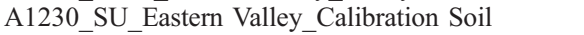 & & & & & & & & & & & & & & & & & \\
\hline- & & & & & & & & & & & & & & & 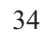 & & 10 \\
\hline 9_SD_E & & & & & & & & & & & & .0 & 0.1 & 0 & 26 & 17 & 10 \\
\hline $6^{-} \mathrm{CD}^{-} \mathrm{D}$ & & & & & & & & & & & & .0 & & & 1 & 17 & 7 \\
\hline $\mathrm{B}$ & & & & & & & & & & & & & & & & & 0 \\
\hline - $\mathrm{R}$ & & & & & & & & & & & & & & & & & 10 \\
\hline-1 & 0. & & & & & & & & & & & & & & 8 & 18 & 10 \\
\hline 325_RU_Ho & & & 0. & & & & & & 6 & 0.07 & & .0 & 0.1 & 9 & 15 & 15 & 7 \\
\hline & & & & & & & & & & & & .0 & & & 6 & 6 & \\
\hline & & & & & & & & & & & & & & & & & \\
\hline & & & & & & & & & & & & & & & 2 & & 6 \\
\hline $\mathrm{C}$ & & & & & & & & & & 0.07 & & .0 & 1 & & 12 & 15 & - \\
\hline SI & & 0. & & 0 & & & & & & 0.09 & & 0.0 & 0.1 & 7 & 22 & 20 & 13 \\
\hline A1368_RB_Home Plate_Pecan Pie & 0.5 & 0.07 & 0.2 & 0.1 & 0.01 & 0.2 & 0.1 & 0.4 & 0.06 & 0.08 & 0.03 & 0.0 & 0.1 & 46 & 20 & 20 & 10 \\
\hline
\end{tabular}

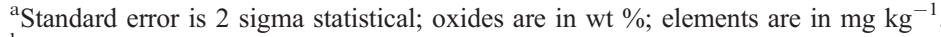

${ }^{b}$ Awxyz BC Feature Target; A, Spirit; wxyz, sol measurement acquired; BC, material and sample preparation (SU, soil surface undisturbed; SD, soil surface disturbed; R, float rock; RU, rock surface undisturbed; RB, rock surface brushed by the RAT; OU, outcrop surface undisturbed; OB, outcrop surface brushed by the RAT; CU, clod surface undisturbed; RBF, failed RAT brush of a rock surface).

${ }^{\mathrm{c}}$ Undisturbed rock surface because of failed RAT brush.
}

normalized to Gusev soil (Figure 2b). Again, the atypical soils (i.e., Boroughs, Paso Robles, Arad, and Gertrude Weise) show distinct variations from Gusev soil because of their unique compositions (see section 7). No drift in the $\mathrm{Si}$ to $\mathrm{Fe}$ ratio for typical soils was noted, indicating that the ratio for excitation with alpha particles and $\mathrm{X}$ rays is still the same as on landing day; that is, there is no noticeable dust accumulation on the sources or detector window.

\section{Trace Elements}

[13] Several trace elements were detected at both MER landing sites with compositions far above the levels present in the APXS calibration sample. These elements $(\mathrm{Br}$ and Ge) have now been calibrated and added to the reported elements for APXS data sets. Bromine was the first of these "new" elements, with concentrations up to $2000 \mathrm{mg} \mathrm{kg}^{-1}$ (or ppm) measured at the Spirit landing site. Bromine was easy to identify because of the uniqueness of its characteristic X-ray energy and its highest response of all elements.

[14] We have looked for evidence of germanium since the beginning of the mission. A clear detection was not made until measurement on the float rock Fuzzy Smith on sol 770. Germanium was not on the list of elements determined in the prelaunch calibration primarily because terrestrial geological samples used for APXS calibration had Ge contents below the detection limit of $20 \mathrm{mg} \mathrm{kg}^{-1}$ and most materials measured early in the mission had $\mathrm{Ge}$ compositions $<20 \mathrm{mg} \mathrm{kg}^{-1}$. We used the calibration curve shown in Figure 4 of Gellert et al. [2006] to extrapolate the Ge response value (signal in counts per second per weight percent) to $3 \mathrm{cps}$ wt $\%^{-1}$. The calibration curve for the APXS method (i.e., excitation of X-ray spectroscopy with alpha particles and high energetic $\mathrm{X}$ rays) is a very smooth function of the X-ray energy because the response depends on the absorption cross sections of the sample elements and the detection efficiency of the $\mathrm{X}$ ray detector. The $\mathrm{Ge} \mathrm{K}_{\alpha}$ energy $(9.89 \mathrm{keV})$ is easy to extrapolate between $\mathrm{Zn}$ and $\mathrm{Br} \mathrm{K} \alpha$ energies. We expect the error in accuracy from this procedure to be less than $\pm 20 \%$ relative.

[15] Germanium X ray peaks have minimal overlap with adjacent peaks of other more abundant elements (e.g., $\mathrm{Zn} \mathrm{K}_{\beta}$ is $250 \mathrm{eV}$ below $\mathrm{Ge}_{\alpha}$ ) and $\mathrm{Ge}$ has a large response (i.e., signal per abundance). An important property of the rock Fuzzy Smith that aided in the identification of the Ge peaks was the low concentration of $\mathrm{Fe}$ in the rock, because this element efficiently absorbs Ge X rays. The Ge signal was recalibrated and Ge content calculated for all samples at the Spirit landing site (Figure 3). Additional calibration measurements are underway to reduce the statistical error. The average Ge content of typical Gusev soil is $\sim 10 \pm 10 \mathrm{mg}$ $\mathrm{kg}^{-1}$ (Table 1). The difficulty of detecting Ge below $10 \mathrm{mg}$ $\mathrm{kg}^{-1}$ results from the low number of counts for the Ge peak and interference from a small background Au peak that is emitted from the gold doors of the sensor head.

[16] Various other trace elements (e.g., $\mathrm{Rb}, \mathrm{Sr}$, and $\mathrm{Y}$ ) have been detected in some Gusev rocks and soils [Clark et al., 2007; Yen et al., 2008], but their concentrations have not been calibrated at the present time.

\section{Geochemical APXS Data Set: Cumberland Ridge to Home Plate}

[17] Spirit's APXS instrument acquired 96 spectra on geologic materials during the trek from Cumberland Ridge to Home Plate (sols 470-1368). Oxide and trace element 
a

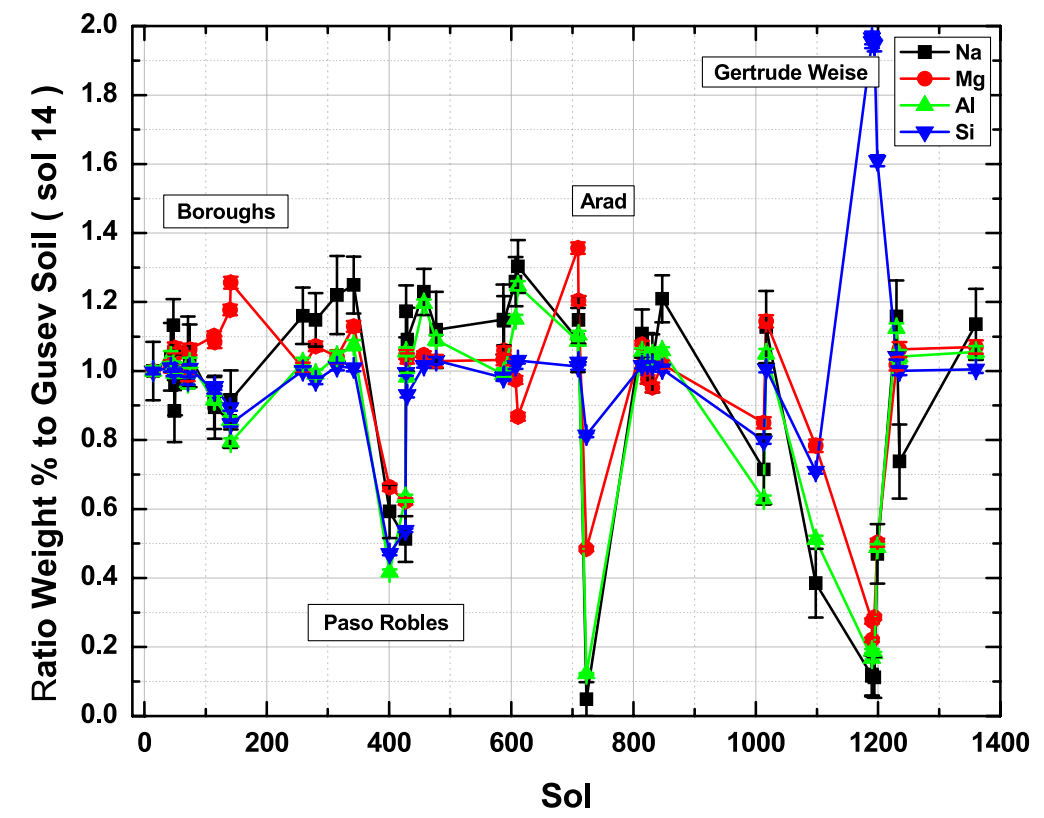

b

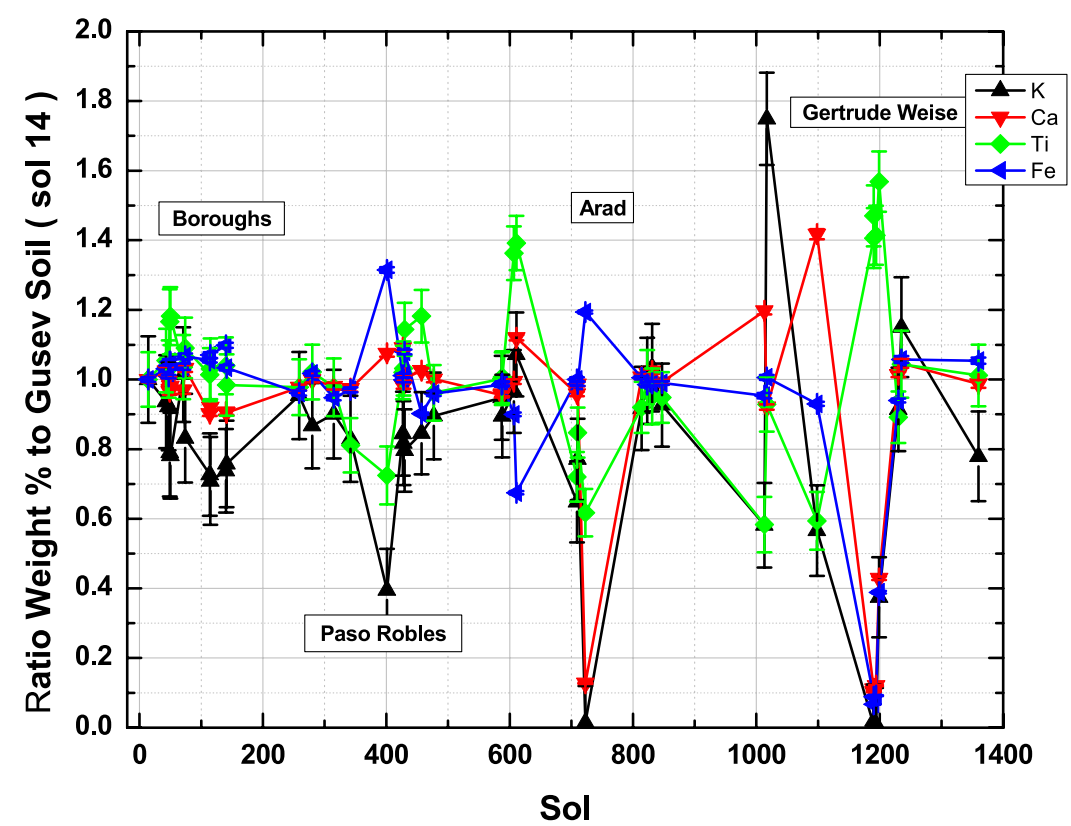

Figure 2. Gusev soil compositions normalized to the composition of the very first soil surface (Gusev soil taken on sol 14) analyzed by the Alpha Particle X-Ray Spectrometer. Typical surface soils exhibit a consistent composition as indicated by a ratio of around one for these soils. Several atypical soils (Boroughs, Paso Robles, Arad, and Gertrude Weise) drastically diverge from the ratio of one, clearly indicating enrichment or depletion of these elements. The consistent nature of these elements in most other typical Gusev surface soils (i.e., Laguna Class) suggests that the calibration has not changed over the course of the mission. (a) Light elements ( $\mathrm{Na}, \mathrm{Mg}, \mathrm{Al}$, and $\mathrm{Si}$ ); (b) heavy elements ( $\mathrm{K}, \mathrm{Ca}, \mathrm{Ti}$, and $\mathrm{Fe}$ ).

compositions for those targets are listed in Table 1. We have grouped targets with similar geochemical compositions into classes based upon observation of chemical differences. Ming et al. [2006] used statistical analysis to devise rock classes during the first 512 sols of Spirit's mission based on
APXS measurements taken on rock surfaces that were ground by the RAT. Statistical methods were appropriate during the early part of the mission because multiple measurements were taken on rocks within a class, e.g., 19 individual APXS measurements on West Spur Clovis Class 


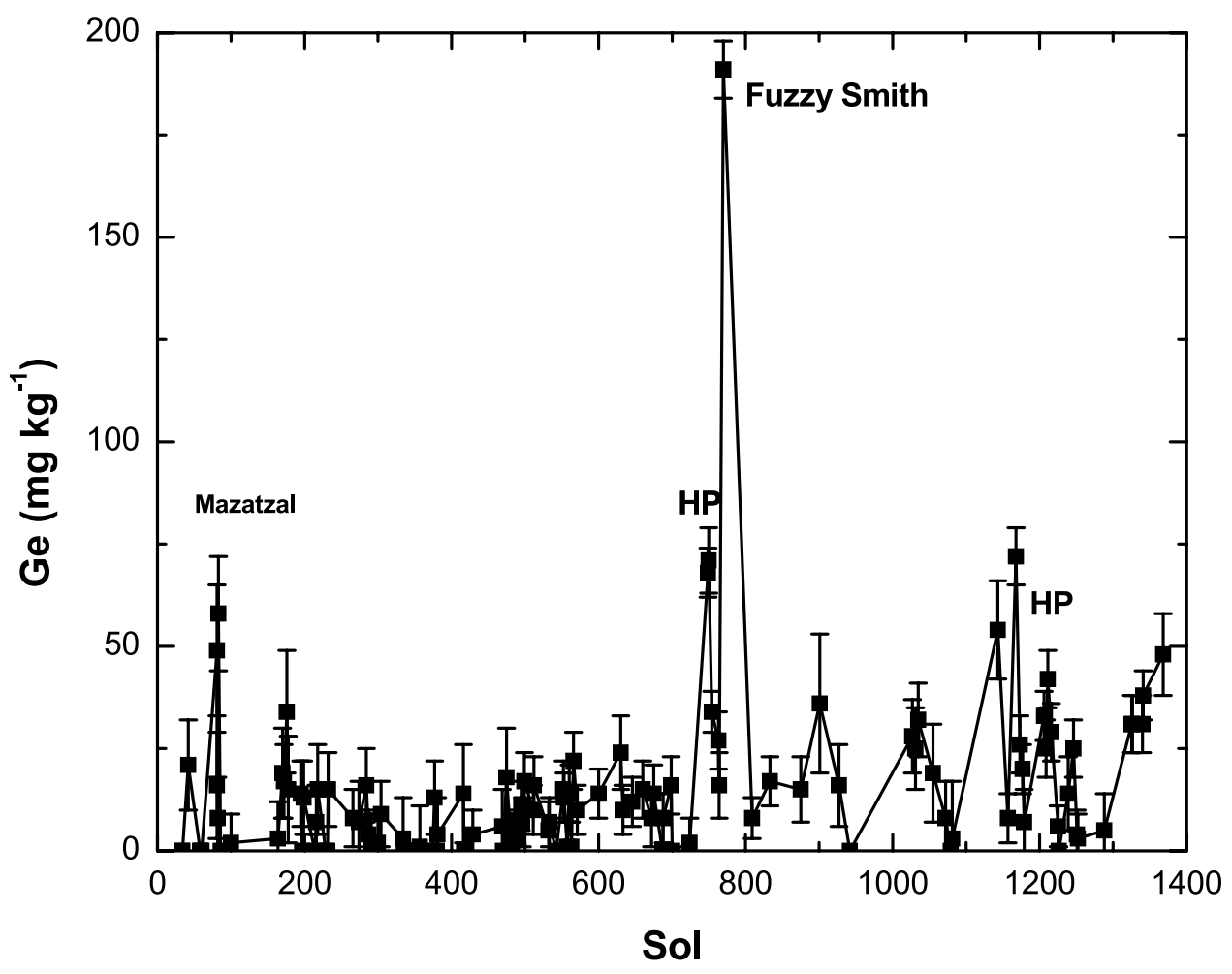

Figure 3. Distribution of germanium in all Gusev rocks is shown as a function of when the rock was encountered by Spirit. Germanium was uniquely identified in the float rock Fuzzy Smith on sol 770. This discovery prompted a recalibration of the Spirit Alpha Particle X-Ray Spectrometer data to include Ge (HP is Home Plate).

rocks [Ming et al., 2006]. The RAT's grinding teeth wore out on sol 417 (RAT grind on the rock Watchtower), precluding APXS analyses on dust-free, cleaned interiors of rocks and outcrops since then.

[18] We include the "best" measurement (i.e., undisturbed versus RAT brushed surfaces) in our rock classification scheme for targets encountered since sol 470. There were only several instances where APXS measurements were made on both undisturbed and RAT brushed surfaces for the same rock. The differences between these two measurements were usually within the statistical errors of the measurements; hence, both measurements were used as an average for the rock surface composition. However, for measurements where there was a difference, only the measurement that appeared to be less contaminated by dust was used to represent the rock's composition. Usually the brushed surface was less contaminated by dust for these cases. Only one or two measurements were made in some rock classes, diminishing the usefulness of statistical analysis. However, there were distinct observable geochemical differences between rocks and soils. Classes were devised on the basis of those distinct geochemical differences. All rock classes are compared to the average Adirondack rock class composition and soil classes were compared to typical Gusev Crater surface soils with the lowest $\mathrm{Fe}^{3+} / \mathrm{Fe}_{\mathrm{T}}$ (i.e., Panda Subclass). Only APXS measurements made on RAT grind surfaces were used to derive an average composition for the Adirondack Class basalts to accommodate a comparison of the rock classes to relatively unaltered basalt.

[19] Six rock and two soil classes were identified by the APXS on Spirit over the course of the first 512 sols of the mission. The rock classes are Adirondack (Gusev plains olivine-rich basalts), Clovis (pervasively altered basaltic materials containing goethite), Peace (Mg- and Ca-sulfate cemented ultramafic basalt grains), Wishstone (high Ti and $\mathrm{P}$ and low $\mathrm{Cr}$ rocks), Watchtower (pervasively altered high Ti and $\mathrm{P}$ and low Cr rocks), and Backstay (trachybasalts) [Ming et al., 2006; Squyres et al., 2006]. The soil classes are Laguna Class (typical Gusev basaltic soils) and Paso Robles Class (very high S soils). Since sol 512, twelve additional rock and two additional soil classes have been identified on the basis of APXS chemistry and Fe mineralogy (Tables 3 and 4, respectively). Several of the classes encountered earlier in the mission are included for comparison with the new classes and new members of those classes are listed in Tables 3 and 4. Average elemental compositions for each rock and soil class are listed in Tables 5 and 6 , respectively, and the auxiliary material ${ }^{1}$. A classification of Gusev rock samples (from sol 1 to 1260), based on Principal Component Analysis (PCA) of the APXS data, was performed by Tréguier et al. [2008]. Their approach leads to the determination of classes consistent with the rock classes presented in this paper (Table 3). The geochemical properties of the rocks and soil classes are presented next.

\section{Rock Classes: Cumberland Ridge to Home Plate} 6.1. Watchtower: Altered and High Ti and P Basalts

[20] Geochemical and mineralogical properties of Watchtower Class rocks have been previously described in detail

${ }^{1}$ Auxiliary materials are available in the HTML. doi:10.1029/ 2008JE003195. 
Table 3. Diagnostic Elemental and Fe Mineralogy Characteristics for Columbia Hills and Inner Basin Rock Classes Encountered Since Sol 470 by Spirit

\begin{tabular}{|c|c|c|c|c|c|}
\hline $\begin{array}{c}\text { APXS Rock } \\
\text { Class } \\
\end{array}$ & $\begin{array}{l}\text { APXS/MB Rock } \\
\text { Class }\end{array}$ & Geographical Location $^{\mathrm{a}}$ & $\begin{array}{l}\text { Representative Rocks } \\
\text { a Within Class }{ }^{\mathrm{b}}\end{array}$ & $\begin{array}{c}\text { Diagnostic Elemental } \\
\text { Characteristics }^{\mathrm{c}}\end{array}$ & $\begin{array}{c}\text { Diagnostic Fe Mineralogy } \\
\text { Characteristics }^{\mathrm{d}}\end{array}$ \\
\hline \multirow[t]{3}{*}{ Watchtower } & $\begin{array}{l}\text { Watchtower } \\
\text { subclass }\end{array}$ & Cumberland Ridge & $\begin{array}{c}\text { Watchtower, Paros, } \\
\text { Pequod }\end{array}$ & $\begin{array}{c}\text { Enriched in } \mathrm{Al}, \mathrm{Ti}, \mathrm{K} \text { and } \mathrm{P} \text { and } \\
\text { depleted in } \mathrm{Fe}, \mathrm{Mn} \text {, and } \mathrm{Cr} \\
\text { compared to plains Adirondack class } \\
\text { Enriched in } \mathrm{Mg} \text { compared to } \\
\text { Wishstone class }\end{array}$ & $\begin{array}{l}\mathrm{NpOx}{ }^{\mathrm{e}}, \text { hematite } \\
\text { goethite }\end{array}$ \\
\hline & Keystone subclass & Cumberland Ridge & Keystone & Same as Watchtower subclass & pyroxene, NpOx, goethite \\
\hline & Keel subclass & $\begin{array}{l}\text { Cumberland Ridge, } \\
\text { Summit, Haskin Ridge }\end{array}$ & $\begin{array}{l}\text { Keel Reef, } \\
\text { Keel Davis, } \\
\text { Hillary, Kansas }\end{array}$ & Same as Watchtower subclass & NpOx, hematite, pyroxene \\
\hline Backstay & Backstay & Cumberland Ridge & $\begin{array}{c}\text { Backstay, } \\
\text { Humboldt Peak? }^{\mathrm{f}}\end{array}$ & $\begin{array}{c}\text { Enriched in } \mathrm{Ti}, \mathrm{Na}, \mathrm{K} \text {, and } \mathrm{Al} \\
\text { and depleted in } \mathrm{Fe}, \mathrm{Mn} \text {, and } \mathrm{Cr} \\
\text { compared to plains Adirondack } \\
\text { basalts }\end{array}$ & $\begin{array}{l}\text { pyroxene, olivine, } \\
\text { magnetite }\end{array}$ \\
\hline Irvine & Irvine & Summit, Low Ridge & $\begin{array}{c}\text { Irvine, Esperanza, } \\
\text { Masada }\end{array}$ & $\begin{array}{c}\text { Enriched in } \mathrm{Ti} \text { and } \mathrm{K} \text { and depleted } \\
\text { in } \mathrm{Ca} \text { and } \mathrm{Cr} \text { compared to } \\
\text { Adirondack basalts } \\
\text { Enriched in } \mathrm{Fe} \text { and } \mathrm{Mn} \text { and } \\
\text { depleted in } \mathrm{Al}, \mathrm{Na} \text {, and } \mathrm{K} \\
\text { compared to Backstay basalts }\end{array}$ & $\begin{array}{c}\text { magnetite, pyroxene, } \\
\text { olivine }\end{array}$ \\
\hline \multicolumn{6}{|l|}{ Independence } \\
\hline $\begin{array}{l}\text { Independence } \\
\text { subclass }\end{array}$ & $\begin{array}{l}\text { Independence } \\
\text { subclass }\end{array}$ & Cumberland Ridge & Independence & $\begin{array}{c}\text { Enriched in } \mathrm{Si}, \mathrm{Al}, \mathrm{Ti}, \mathrm{P}, \mathrm{K}, \& \mathrm{Ni} \\
\text { and strongly depleted in } \mathrm{Fe}, \mathrm{Mn} \text {, } \\
\mathrm{Mg}, \& \mathrm{Cr} \text { compared to Adirondack } \\
\text { basalts }\end{array}$ & $\begin{array}{l}\text { NpOx, pyroxene, } \\
\text { ilmenite }\end{array}$ \\
\hline Assemblee subclass & $\begin{array}{l}\text { Assemblee } \\
\text { subclass }\end{array}$ & Cumberland Ridge & Assemblee & $\begin{array}{c}\text { Strongly enriched in } \mathrm{Cr} \text { and } \\
\text { enriched in } \mathrm{Mg} \& \mathrm{~K} \text { and } \\
\text { depleted in } \mathrm{Ti}, \mathrm{Ca}, \mathrm{Na}, \& \mathrm{P} \\
\text { compared to Independence }\end{array}$ & $\begin{array}{l}\text { pyroxene, } \mathrm{NpOx}, \\
\text { chromite }\end{array}$ \\
\hline Descartes & Descartes & $\begin{array}{c}\text { Cumberland Ridge, } \\
\text { Summit }\end{array}$ & $\begin{array}{l}\text { Descartes, Gentil } \\
\text { Matrice, } \\
\text { Haussman }\end{array}$ & $\begin{array}{l}\text { Enriched in } \mathrm{Ti}, \mathrm{K}, \mathrm{P} \text {, and } \mathrm{Ni} \text { and } \\
\text { depleted in } \mathrm{Fe}, \mathrm{Mn}, \mathrm{Ca} \text {, and } \\
\mathrm{Cr} \text { compared to plains } \\
\text { Adirondack basalts } \\
\text { Enriched in } \mathrm{Fe} \text { and } \mathrm{Mn} \text { and } \\
\text { depleted in } \mathrm{Al} \text { and } \mathrm{Ni} \text { compared } \\
\text { to Independence class }\end{array}$ & $\begin{array}{l}\text { NpOx, pyroxene, } \\
\text { magnetite }\end{array}$ \\
\hline \multirow[t]{2}{*}{ Algonquin } & $\begin{array}{l}\text { Algonquin } \\
\text { subclass }\end{array}$ & Haskin Ridge & $\begin{array}{l}\text { Seminole, Algonquin, } \\
\text { Larry's Bench }\end{array}$ & $\begin{array}{l}\text { Enriched in } \mathrm{Fe}, \mathrm{Mg} \text {, and } \mathrm{Ni} \text { and } \\
\text { depleted in } \mathrm{Al} \text {, and } \mathrm{Ca} \text { compared } \\
\text { to plains Adirondack basalts }\end{array}$ & $\begin{array}{c}\text { olivine, } \mathrm{NpOx}, \\
\text { pyroxene }\end{array}$ \\
\hline & $\begin{array}{l}\text { Comanche } \\
\text { subclass }\end{array}$ & Haskin Ridge & Comanche & $\begin{array}{c}\text { Similar trends to Algonquin } \\
\text { Most ultramafic outcrop in } \\
\text { Algonquin series }\end{array}$ & $\begin{array}{c}\text { olivine, pyroxene, } \\
\text { NpOx }\end{array}$ \\
\hline \multicolumn{6}{|l|}{ Barnhill } \\
\hline Barnhill subclass & Barnhill subclass & Home Plate & $\begin{array}{l}\text { Barnhill, Posey, } \\
\text { James Cool Papa } \\
\text { Bell, Pecan Pie }\end{array}$ & $\begin{array}{c}\text { Enriched in } \mathrm{Ti}, \mathrm{K}, \mathrm{P}, \mathrm{Cl}, \mathrm{Ni}, \mathrm{Zn} \text {, } \\
\& \mathrm{Br} \text { and depleted in } \mathrm{Ca} \& \mathrm{Cr} \\
\text { compared to plains Adirondack } \\
\text { basalts }\end{array}$ & $\begin{array}{l}\text { NpOx, magnetite } \\
\text { pyroxene }\end{array}$ \\
\hline Pesapallo subclass & $\begin{array}{c}\text { Pesapallo } \\
\text { subclass }\end{array}$ & Home Plate & $\begin{array}{l}\text { Madeline English, } \\
\text { Pesapallo, Superpesis, } \\
\text { June Emerson, } \\
\text { Elizabeth Emery, } \\
\text { Texas Chili }\end{array}$ & $\begin{array}{l}\text { Similar to Barnhill subclass except } \\
\text { enriched in } \mathrm{K}, \mathrm{Ni}, \& \mathrm{Zn} \\
\text { and depleted in } \mathrm{Cl} \& \mathrm{Br}\end{array}$ & $\begin{array}{c}\text { magnetite, pyroxene, } \\
\text { NpOx }\end{array}$ \\
\hline Fuzzy Smith & Fuzzy Smith & Home Plate & Fuzzy Smith & $\begin{array}{l}\text { Strongly Enriched in } \mathrm{Si}, \mathrm{Ti}, \mathrm{K}, \mathrm{Zn} \text {, } \\
\text { and } \mathrm{Ge} \text { and depleted in } \mathrm{Al}, \mathrm{Fe}, \mathrm{Mn} \text {, } \\
\mathrm{Mg}, \mathrm{Ca} \text {, and } \mathrm{Cr} \text { compared to plains } \\
\text { Adirondack basalts }\end{array}$ & $\begin{array}{c}\text { unidentified Fe phase, } \\
\text { pyroxene, ilmenite }\end{array}$ \\
\hline \multicolumn{6}{|l|}{ Elizabeth Mahon } \\
\hline $\begin{array}{l}\text { Elizabeth Mahon } \\
\text { subclass }\end{array}$ & $\begin{array}{c}\text { Elizabeth Mahon } \\
\text { subclass }\end{array}$ & Eastern Valley & $\begin{array}{l}\text { Elizabeth Mahon, } \\
\text { Nancy Warren, } \\
\text { Norma Luker }\end{array}$ & $\begin{array}{l}\text { Strongly enriched in } \mathrm{Si}, \mathrm{Ni}, \& \mathrm{Zn} \\
\text { \& depleted in } \mathrm{Al}, \mathrm{Fe}, \mathrm{Mn}, \mathrm{Mg} \\
\mathrm{Ca}, \mathrm{Na}, \& \mathrm{Cr} \text { compared to } \\
\text { Adirondack basalts }\end{array}$ & $\begin{array}{l}\text { NpOx, pyroxene, } \\
\text { magnetite }\end{array}$ \\
\hline $\begin{array}{l}\text { Innocent } \\
\text { Bystander } \\
\text { subclass }\end{array}$ & $\begin{array}{c}\text { Innocent Bystander } \\
\text { subclass }\end{array}$ & Eastern Valley & Innocent Bystander & $\begin{array}{c}\text { Enriched in } \mathrm{Si}, \mathrm{Mg}, \mathrm{Ni}, \& \mathrm{Zn} \\
\text { \& depleted in } \mathrm{Al}, \mathrm{Fe}, \mathrm{Mn}, \\
\mathrm{Ca}, \mathrm{Na}, \mathrm{K}, \mathrm{P}, \text { \& } \mathrm{Cr} \text { compared } \\
\text { to Adirondack basalts } \\
\text { Enriched in } \mathrm{Fe}, \mathrm{Mg}, \& \mathrm{Zn} \& \\
\text { depleted in } \mathrm{Al}, \mathrm{Mn}, \mathrm{Ca}, \mathrm{Na}, \mathrm{K}, \\
\text { \& } \mathrm{P} \text { compared to Elizabeth } \\
\text { Mahon subclass }\end{array}$ & $\begin{array}{l}\text { magnetite, } \mathrm{NpOx}, \\
\text { pyroxene }\end{array}$ \\
\hline
\end{tabular}


Table 3. (continued)

\begin{tabular}{|c|c|c|c|c|c|}
\hline $\begin{array}{l}\text { APXS Rock } \\
\text { Class }\end{array}$ & $\begin{array}{l}\text { APXS/MB Rock } \\
\text { Class }\end{array}$ & Geographical Location $^{\mathrm{a}}$ & $\begin{array}{l}\text { Representative Rocks } \\
\text { Within Class }^{\text {b }}\end{array}$ & $\begin{array}{l}\text { Diagnostic Elemental } \\
\text { Characteristics }^{c}\end{array}$ & $\begin{array}{c}\text { Diagnostic Fe Mineralogy } \\
\text { Characteristics }^{\mathrm{d}}\end{array}$ \\
\hline \multicolumn{6}{|l|}{ Halley } \\
\hline Halley subclass & Halley subclass & Low Ridge & Halley & $\begin{array}{c}\text { Enriched in } \mathrm{Ti}, \mathrm{K}, \mathrm{S}, \mathrm{Ni}, \& \mathrm{Zn} \\
\text { \& depleted in } \mathrm{Fe}, \mathrm{Mn}, \& \mathrm{Cr} \\
\text { compared to Adirondack basalts }\end{array}$ & $\begin{array}{c}\text { hematite, magnetite, } \\
\text { pyroxene }\end{array}$ \\
\hline $\begin{array}{l}\text { Graham Land } \\
\text { subclass }\end{array}$ & $\begin{array}{l}\text { Graham Land } \\
\text { subclass }\end{array}$ & Low Ridge & $\begin{array}{l}\text { King George } \\
\text { Island, Riquelme }\end{array}$ & $\begin{array}{l}\text { Similar to Halley subclass except } \\
\text { enriched in } \mathrm{K}, \mathrm{P}, \mathrm{Ni} \& \mathrm{Br} \\
\text { \& depleted in } \mathrm{Ca} \& \mathrm{~S}\end{array}$ & $\begin{array}{c}\text { hematite, magnetite, } \\
\text { pyroxene }\end{array}$ \\
\hline Montalva & Montalva & Low Ridge & Montalva & $\begin{array}{l}\text { Strongly enriched in } \mathrm{K} \text { and } \\
\text { enriched in } \mathrm{Ti}, \mathrm{Mg}, \mathrm{Ni} \text {, and } \mathrm{Zn} \\
\text { and strongly depleted in } \mathrm{Al}, \mathrm{Mn} \text {, } \\
\mathrm{Ca}, \mathrm{Na} \text {, and } \mathrm{Cr} \text { compared to } \\
\text { Adirondack basalts }\end{array}$ & $\begin{array}{c}\text { hematite, } \\
\text { magnetite, NpOx }\end{array}$ \\
\hline Everett & Everett & Eastern Valley & Everett, Slide & $\begin{array}{l}\text { Enriched in } \mathrm{Mg}, \mathrm{K}, \mathrm{Cl}, \mathrm{Ni}, \mathrm{Zn} \text {, } \\
\text { and } \mathrm{Br} \text { and depleted in } \mathrm{Ti}, \mathrm{Al} \text {, } \\
\mathrm{Mn}, \mathrm{Ca} \text {, and } \mathrm{Na} \text { compared to } \\
\text { Adirondack basalts } \\
\text { Enriched in } \mathrm{Mg} \text { and depleted in } \\
\mathrm{Ti}, \mathrm{Al}, \mathrm{Ca}, \mathrm{Na} \text {, and } \mathrm{P} \text { compared } \\
\text { to Good Question and Torquas }\end{array}$ & $\begin{array}{c}\text { magnetite, pyroxene, } \\
\text { NpOx }\end{array}$ \\
\hline Good Question & Good Question & Eastern Valley & Good Question & $\begin{array}{c}\text { Enriched in } \mathrm{Si}, \mathrm{Mg}, \mathrm{K}, \mathrm{Cl}, \mathrm{Ni} \text {, } \\
\mathrm{Zn} \text {, and } \mathrm{Br} \text { and depleted in } \\
\mathrm{Al}, \mathrm{Mn}, \mathrm{Ca} \text {, and } \mathrm{Na} \text { compared to } \\
\text { Adirondack basalts } \\
\text { Enriched in } \mathrm{Si} \text { and depleted in } \\
\mathrm{Mn} \text { compared to Everett and } \\
\text { Torquas }\end{array}$ & $\begin{array}{l}\text { pyroxene, } \mathrm{NpOx}, \\
\text { magnetite }\end{array}$ \\
\hline Torquas & Torquas & Mitcheltree Ridge & Torquas & $\begin{array}{c}\text { Enriched in } \mathrm{Mg}, \mathrm{K}, \mathrm{Cl}, \mathrm{Ni}, \mathrm{Zn}, \\
\text { and } \mathrm{Br} \text { and depleted in } \mathrm{Al}, \\
\mathrm{Mn}, \mathrm{Ca}, \mathrm{Na} \text {, and } \mathrm{P} \text { compared to } \\
\text { Adirondack basalts } \\
\text { Enriched in } \mathrm{Ti}, \mathrm{K}, \mathrm{P}, \mathrm{Ni} \text {, and } \mathrm{Zn} \\
\text { and depleted in } \mathrm{Cr} \text { compared } \\
\text { to Everett and Good Question }\end{array}$ & $\begin{array}{l}\text { magnetite, } \mathrm{NpOx}, \\
\text { pyroxene }\end{array}$ \\
\hline Adirondack $^{\mathrm{g}}$ & Adirondack & Home Plate & Humboldt Peak ${ }^{\mathrm{f}}$ & Typical Gusev crater olivine-rich basalt & $\begin{array}{c}\text { olivine, magnetite, } \\
\text { pyroxene }\end{array}$ \\
\hline
\end{tabular}

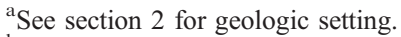

${ }^{b}$ Rock names listed here taken from either the feature or target name (see Table 1).

${ }^{c}$ Elemental characteristics based upon visual comparisons of plotted data.

${ }^{\mathrm{d}}$ From Morris et al. [2008a]. Trace Fe phases not reported here.

${ }^{\mathrm{e}} \mathrm{NpOx}$ is nanophase ferric oxides.

${ }_{\mathrm{f}}^{\mathrm{f}}$ Humboldt Peak is an alkaline basalt with many chemical similarities to the Adirondack Class basalts so it is not clear if this rock is in the Backstay, Adirondack, or a new rock class.

${ }^{\mathrm{g}}$ Adirondack Class rocks are typical Gusev olivine-rich basalts first discovered near the Spirit landing site out on the Gusev plains [Gellert et al., 2004, 2006].
}

[Squyres et al., 2006; Gellert et al., 2006; Ming et al., 2006; Morris et al., 2006; Ruff et al., 2006]. APXS data for rocks not included in the work by Gellert et al. [2006] are described here and listed in Table 3. The most prominent exposure of Watchtower Class rock is the Methuselah Outcrop on Cumberland Ridge. Additional outcrops of Watchtower Class material are near the Husband Hill summit (Hillary) and on the descent from the summit on Haskin Ridge (Kansas).

[21] High $\mathrm{Ti}\left(1.9\right.$ average wt $\left.\% \mathrm{TiO}_{2}\right)$ and $\mathrm{P}(2.6$ average wt $\% \mathrm{P}_{2} \mathrm{O}_{5}$ ) are the most notable geochemical features of Watchtower Class rocks. High Ti and $\mathrm{P}$ are also diagnostic geochemical properties of Wishstone Class rocks [Gellert et al., 2006; Ming et al., 2006], but Watchtower Class rocks have about twice as much $\mathrm{Mg}$ as Wishstone Class rocks (8.4 average wt \% $\mathrm{MgO}$ for Watchtower Class) and some Watchtower rocks are pervasively altered compared to Wishstone rocks [Morris et al., 2006]. Hurowitz et al. [2006a] have proposed a mixing relationship between Wishstone and Watchtower Class materials.

[22] Watchtower rocks are enriched in $\mathrm{Ti}, \mathrm{Al}, \mathrm{Na}, \mathrm{K}, \mathrm{P}$ and $\mathrm{Cl}$ and depleted in $\mathrm{Fe}, \mathrm{Mn}, \mathrm{Cr}, \mathrm{Ni}$ and $\mathrm{Zn}$ compared to
Adirondack Class basalts (Figure 4a). Higher Na, K and Al likely reflect the presence of alkali feldspars and/or their alteration products [Ming et al., 2006]. The Fe mineralogy varies substantially within Watchtower Class rocks [Morris et al., 2006], so that subclasses have been formed to accommodate this variation in mineralogy (Table 3). Elemental geochemistry however does not vary between the subclasses (Figure 4b).

[23] Watchtower mineralogy consists of Fe-oxides/oxyhydroxides (npOx, hematite, goethite, magnetite), ilmenite, Ca-phosphates (e.g., brushite), Mg-sulfates, secondary aluminosilicates, olivine, and pyroxene [Ming et al., 2006; Morris et al., 2006] and a significant glass or amorphous silicate phase [Ruff et al., 2006]. Relatively high content of volatile elements (i.e., $\mathrm{Cl}, \mathrm{S}$, and $\mathrm{Br}$ ) and the pervasive degree of alteration (i.e., Mineralogical Alteration Index $(\mathrm{MAI})=37-94$ [Morris et al., 2008a]) suggest that Watchtower Class materials were altered by solutions enriched in these elements. The water to rock ratio however must have been low to prevent leaching or removal of soluble elements; this is indicated by the similar geochemical compositions 
Table 4. Diagnostic Elemental and Fe Mineralogy Characteristics for the Gusev Crater Soil Classes

\begin{tabular}{|c|c|c|c|c|c|}
\hline $\begin{array}{l}\text { APXS Soil } \\
\text { Class } \\
\end{array}$ & APXS/MB Soil Class & Location $^{\mathrm{a}}$ & Representative Soils within Class ${ }^{\mathrm{b}}$ & Diagnostic Elemental Characteristics $^{\mathrm{c}}$ & $\begin{array}{l}\text { Diagnostic Fe } \\
\text { Mineralogy } \\
\text { Characteristics } \\
\end{array}$ \\
\hline \multirow[t]{5}{*}{ Laguna } & Panda subclass & El Dorado & $\begin{array}{l}\text { El Dorado, Laguna Hollow, } \\
\text { Shredded, Goldfinger }\end{array}$ & $\begin{array}{l}\text { Enriched in } \mathrm{Ti}, \mathrm{Mg}, \mathrm{K}, \mathrm{S}, \mathrm{Zn} \text {, and } \\
\mathrm{Br} \text { and higher } \mathrm{Fe}^{3+} / \mathrm{Fe}_{\mathrm{T}} \text { compared } \\
\text { to Adirondack class basalts }\end{array}$ & $\begin{array}{l}\text { olivine, } \\
\text { pyroxene, } \\
\text { NpOx }\end{array}$ \\
\hline & Liberty subclass & $\begin{array}{l}\text { Cumberland Ridge, } \\
\text { Low Ridge }\end{array}$ & $\begin{array}{c}\text { Liberty Bell, Progress } 1, \\
\text { Progress } 2, \text { Mawson, Bear } \\
\text { Island, Mimi Tracks, Mayfly, } \\
\text { Trout, Coffee, Yams, Paso Dark }\end{array}$ & $\begin{array}{c}\text { Enriched in } \mathrm{P}, \mathrm{Cl}, \mathrm{S}, \mathrm{Zn}, \mathrm{Br} \\
\text { and a higher } \mathrm{Fe}^{3+} / \mathrm{Fe}_{\mathrm{T}} \text { compared } \\
\text { to Panda subclass }\end{array}$ & $\begin{array}{l}\text { olivine, } \\
\text { pyroxene, } \\
\text { NpOx }\end{array}$ \\
\hline & Gobi subclass & Summit, Low Ridge & $\begin{array}{l}\text { Lambert, Progress, Gusev } \\
\text { Soil, Gobi, Cutthroat, Conjunction } \\
\text { Junction }\end{array}$ & $\begin{array}{c}\text { Enriched in } \mathrm{Cl}, \mathrm{S}, \mathrm{Zn} \text { and } \mathrm{Br} \text { and } \\
\text { a higher } \mathrm{Fe}^{3+} / \mathrm{Fe}_{\mathrm{T}} \text { compared to } \\
\text { Liberty subclass }\end{array}$ & $\begin{array}{l}\text { pyroxene, } \\
\text { NpOx, } \\
\text { olivine }\end{array}$ \\
\hline & Boroughs subclass & Gusev Plains & RS2, Mill Basin, Hells Kitchen & $\begin{array}{c}\text { Enriched in } \mathrm{Cl}, \mathrm{S} \text {, and } \mathrm{Br} \text { and } \\
\text { higher } \mathrm{Fe}^{3+} / \mathrm{Fe}_{\mathrm{T}} \text { compared to } \\
\text { Gobi subclass }\end{array}$ & $\begin{array}{l}\text { olivine, } \\
\text { NpOx, } \\
\text { pyroxene }\end{array}$ \\
\hline & Doubloon subclass & $\begin{array}{c}\text { Cumberland Ridge, } \\
\text { Summit }\end{array}$ & Doubloon, Cliffhanger_HangTwo & $\begin{array}{c}\text { Enriched in } \mathrm{Ti}, \mathrm{Al}, \mathrm{Ca} \text {, and } \mathrm{P} \text { and } \\
\text { depleted in } \mathrm{Fe}, \mathrm{Mn}, \mathrm{Cr} \text {, and } \mathrm{Ni} \\
\text { compared to other Laguna subclasses } \\
\text { and similar } \mathrm{Fe}^{3+} / \mathrm{Fe}_{\mathrm{T}} \text { to Boroughs } \\
\text { subclass }\end{array}$ & $\begin{array}{l}\text { olivine, } \\
\text { pyroxene, } \\
\text { NpOx }\end{array}$ \\
\hline Paso Robles & Paso Robles & $\begin{array}{l}\text { El Dorado, } \\
\text { Low Ridge }\end{array}$ & $\begin{array}{c}\text { Arad, Berkner Island, Mount } \\
\text { Darwin, Paso Robles }\end{array}$ & $\begin{array}{l}\text { Highly enriched in } \mathrm{S} \text { and } \mathrm{Br} \text { and } \\
\text { depleted in } \mathrm{Si}, \mathrm{Ti}, \mathrm{Al}, \mathrm{Mn}, \mathrm{Mg}, \mathrm{Na} \text {, } \\
\mathrm{K} \text {, and } \mathrm{Cl} \text { compared to Panda } \\
\text { subclass } \\
\text { Substantial elemental variation } \\
\text { within Paso Robles class materials }\end{array}$ & $\begin{array}{l}\text { ferric sulfate, } \\
\text { hematite, } \\
\text { pyroxene, } \\
\text { olivine }\end{array}$ \\
\hline $\begin{array}{l}\text { Gertrude } \\
\text { Weise }\end{array}$ & Gertrude Weise & Eastern Valley & Gertrude Weise, Lefty Ganote & $\begin{array}{c}\text { Strongly Enriched in } \mathrm{Si} \text { and } \mathrm{Ti} \text { and } \\
\text { depleted in } \mathrm{Al}, \mathrm{Fe}, \mathrm{Mn}, \mathrm{Mg} \text {, } \\
\mathrm{Ca}, \mathrm{Na}, \mathrm{K}, \mathrm{P}, \mathrm{Cl}, \mathrm{S}, \mathrm{Ni} \text {, and } \mathrm{Br} \\
\text { compared to Panda subclass }\end{array}$ & $\begin{array}{l}\text { NpOx, } \\
\text { pyroxene, } \\
\text { olivine }\end{array}$ \\
\hline Eileen Dean & Eileen Dean & Eastern Valley & Eileen Dean & $\begin{array}{c}\text { Enriched in } \mathrm{Mg}, \mathrm{Cl}, \mathrm{Zn} \text {, and } \mathrm{Br} \\
\text { and depleted in } \mathrm{Ti}, \mathrm{Al}, \mathrm{Mn}, \mathrm{Ca} \text {, } \\
\mathrm{Na}, \mathrm{P} \text { and } \mathrm{S} \text { compared to Panda } \\
\text { subclass }\end{array}$ & $\begin{array}{l}\text { magnetite, } \\
\text { pyroxene, } \\
\text { olivine }\end{array}$ \\
\hline
\end{tabular}

\footnotetext{
${ }^{\mathrm{a}}$ See section 2 for geologic setting.

${ }^{b}$ Rock names listed here taken from either the feature or target name. Names listed in italics are for measurements taken between sols 470 and 1368 . Nonitalicized names are for measurements taken between sols 0 and 470 (see Gellert et al. [2006] for soil measurements for the first 470 sols of Spirit's mission).

${ }^{c}$ Elemental characteristics based upon visual comparisons of plotted data.

${ }^{\mathrm{d}}$ From Morris et al. [2008a]. Trace Fe phases not reported here.

${ }^{\mathrm{e}} \mathrm{NpOx}$ is nanophase $\mathrm{Fe}$ oxides.
}

of all members of the subclasses. Acid sulfate weathering similar to the process described for West Spur Clovis Class materials may have altered Watchtower rocks [Ming et al., 2006; Hurowitz et al., 2006b].

\subsection{Backstay and Irvine: Alkaline Volcanic Rocks 6.2.1. Backstay: Trachybasalt}

[24] Backstay is a float rock discovered on Cumberland Ridge with Mini-Thermal Emission Spectrometer (Mini-TES) [Arvidson et al., 2006; Ruff et al., 2006]. At least nine other examples have been identified with Mini-TES [Ruff et al., 2006] but only Backstay was examined by the full Athena payload. It is enriched in $\mathrm{Ti}, \mathrm{Al}, \mathrm{Na}, \mathrm{K}$, and $\mathrm{P}$ and depleted in $\mathrm{Fe}, \mathrm{Mn}$, and $\mathrm{Cr}$ compared to Adirondack Class basalts (Figure 4a). The sum of the alkali cations is nearly twice as high in Backstay $\left(\mathrm{Na}_{2} \mathrm{O}+\mathrm{K}_{2} \mathrm{O}=5.0\right.$ wt \%) compared to Adirondack Class rocks $\left(\mathrm{Na}_{2} \mathrm{O}+\mathrm{K}_{2} \mathrm{O}=2.9\right.$ average wt \%). The rock is relatively unaltered and consists of primary mineral phases [Morris et al., 2006; Ming et al., 2006]. Backstay has been classified as a trachybasalt [Ming et al., 2006; McSween et al., 2006b]. Detailed geochemical, mineralogical, and spectral characterization of Backstay Class trachybasalt can be found in the work by $M c$ Sween et al. [2006b].
[25] Humboldt Peak is a high $\mathrm{Na}_{2} \mathrm{O}+\mathrm{K}_{2} \mathrm{O}(5.46 \mathrm{wt} \%)$ float rock on top of Home Plate. Humboldt Peak is alkaline basalt because of the high $\mathrm{Na}_{2} \mathrm{O}+\mathrm{K}_{2} \mathrm{O}$; however, the other oxide contents of Humboldt Peak are similar to Adirondack Class basalts and not Backstay. It is not clear whether Humboldt Peak is a member of Backstay, Adirondack, or perhaps a new class.

\subsubsection{Irvine: Subalkaline Basalt}

[26] Irvine is a relatively unaltered float rock that was first observed by Mini-TES near the summit of Husband Hill along with at least four other spectrally and morphologically similar examples [Ruff et al., 2006]. Only Backstay was analyzed by the full Athena analytical suite of instruments near the summit. Two additional rocks, Masada and Esperanza, with compositions similar to Irvine were encountered by Spirit south of the El Dorado ripple field and at Low Ridge near Spirit's Winter Campaign site (2nd winter) in the Inner Basin, respectively. Masada and Esperanza have vesicular textures whereas Irvine is a massive rock. Irvine Class rocks are geochemically similar to Backstay in many respects except that Irvine is enriched in $\mathrm{Fe}, \mathrm{Mn}$, and $\mathrm{Ni}$ and depleted in $\mathrm{Al}, \mathrm{Na}, \mathrm{K}$, and $\mathrm{P}$. Irvine has an average $\mathrm{FeO}$ content of $19.7 \mathrm{wt} \%$ compared to $13.2 \mathrm{wt} \% \mathrm{FeO}$ in Backstay. Irvine is enriched in $\mathrm{Ti}, \mathrm{K}, \mathrm{P}, \mathrm{Ni}$, and $\mathrm{Zn}$ and 
Table 5. Average Elemental Compositions for Rock Classes on Husband Hill and in the Inner Basin ${ }^{\mathrm{a}}$

\begin{tabular}{|c|c|c|c|c|c|c|c|c|c|c|c|c|c|c|c|c|c|c|}
\hline \multirow[b]{2}{*}{ Rock Class } & \multirow[b]{2}{*}{$\mathrm{N}^{\mathrm{b}}$} & \multicolumn{13}{|c|}{ Oxides } & \multicolumn{4}{|c|}{ Elements } \\
\hline & & $\mathrm{SiO}_{2}$ & $\mathrm{TiO}_{2}$ & $\mathrm{Al}_{2} \mathrm{O}_{3}$ & $\mathrm{FeO}$ & $\mathrm{MnO}$ & $\mathrm{MgO}$ & $\mathrm{CaO}$ & $\mathrm{Na}_{2} \mathrm{O}$ & $\mathrm{K}_{2} \mathrm{O}$ & $\mathrm{P}_{2} \mathrm{O}_{5}$ & $\mathrm{Cr}_{2} \mathrm{O}_{3}$ & $\mathrm{Cl}$ & $\mathrm{SO}_{3}$ & $\mathrm{Ni}$ & $\mathrm{Zn}$ & $\mathrm{Br}$ & $\mathrm{Ge}$ \\
\hline Adirondack & 5 & 45.9 & 0.58 & 10.6 & 18.7 & 0.41 & 9.9 & 7.9 & 2.6 & 0.15 & 0.63 & 0.58 & 0.3 & 1.7 & 201 & 121 & 84 & 2 \\
\hline Watchtower & 14 & 45.6 & 1.93 & 12.6 & 11.8 & 23 & 8.4 & 6.6 & 3.4 & 0.49 & 2.64 & .05 & 1.2 & 4.9 & 109 & 114 & 257 & 9 \\
\hline Backstay & 2 & 49.4 & 0.93 & 13.1 & 13.2 & 0.25 & 8.3 & 6.0 & 4.0 & 02 & 1.34 & 16 & 0.4 & 1.8 & 210 & 272 & 21 & 13 \\
\hline Irvine & 2 & 47.5 & 1.06 & 8.3 & 19.7 & 0.37 & 9.5 & 5.8 & 3.0 & 0.60 & 0.94 & 0.20 & 0.5 & 2.4 & 342 & 299 & 93 & 17 \\
\hline Independence subclass & 3 & 53.7 & 1.57 & 15.0 & 6.4 & 0.12 & 4.7 & 6.5 & 2.9 & 0.70 & 3.01 & 0.11 & 0.5 & 4.5 & 1036 & 293 & 61 & 4 \\
\hline Assemblee subclass & 2 & 50.7 & 0.92 & 17.0 & 6.6 & 0.15 & 7.9 & 4.2 & 1.8 & 0.97 & 1.72 & 2.77 & 0.9 & 4.1 & 1211 & 246 & 65 & 16 \\
\hline Descartes & 4 & 46.1 & 0.98 & 10.4 & 13.2 & 0.22 & 9.4 & 5.5 & 3.2 & 0.64 & 1.42 & 0.16 & 1.2 & 7.5 & 410 & 215 & 161 & 11 \\
\hline uin series & 7 & 41.9 & 0.58 & 6.4 & 20.9 & 0.39 & 16.0 & 4.0 & 2.3 & 0.40 & 1.04 & 0.57 & 0.9 & 4.5 & 704 & 176 & 116 & 9 \\
\hline Barnhill subclass & 6 & 45.8 & 0.90 & 9.1 & 16.6 & 0.35 & 10.0 & 6.4 & 3.0 & 0.29 & 1.09 & 0.39 & 1.6 & 4.4 & 337 & 406 & 260 & 44 \\
\hline$P$ & 7 & 46.4 & 0.99 & 9.8 & 16.0 & 0.32 & 9.3 & 6.2 & 3.0 & 0.53 & 1.15 & & 1.0 & 4.8 & 120 & 593 & 85 & 38 \\
\hline $\mathrm{F}$ & 1 & 68.4 & 1.71 & 6.3 & 68 & 0.15 & 4.2 & 1.9 & 2.9 & 2.76 & 0.68 & 6 & 0.6 & 3. & 272 & 679 & 21 & 191 \\
\hline pclass & 4 & 71.8 & 0.67 & 5.1 & 6.8 & 0.12 & 5.7 & 3.0 & 1.6 & 0.25 & 0.60 & 5 & 0.5 & 3. & 37 & 359 & 39 & 5 \\
\hline at Bystander subclass & 2 & 62.4 & 0.58 & 2.7 & 13.5 & 0.08 & 13.4 & 1.6 & 0.4 & 0.05 & 0.46 & 4 & 0.5 & 3. & 624 & 804 & 90 & 4 \\
\hline & 2 & 45.6 & 0.45 & 4.6 & 19.1 & 0.31 & 19.7 & 2.6 & 0.8 & 0.57 & 0.56 & 0.58 & 1.4 & 24 & 847 & 1159 & 234 & 23 \\
\hline & 1 & 53.9 & 0.73 & 6 & 14.8 & 0.20 & 10.8 & 2 & 2 & 2 & 0.72 & & 1.5 & 4 & 96 & 1030 & 245 & 7 \\
\hline & 4 & 43.7 & 0.76 & $9.2-2$ & 15.3 & 0.28 & 8.2 & 7.9 & 2.9 & 0.45 & 0.83 & & 0.6 & 9 & 128 & 888 & 23 & 17 \\
\hline subclass & 4 & 47.5 & 0.96 & 10.1 & 14.7 & 0.29 & 9.4 & 5.7 & 2.6 & 1.35 & 1.08 & 1 & 0.8 & 4.9 & 765 & 1167 & 126 & 22 \\
\hline Mor & 2 & 45.3 & 0.88 & 6.6 & 19.2 & 0.14 & 12.9 & 3.3 & 1.1 & 2.91 & 0.68 & 0.14 & 1.0 & 5.6 & 792 & 608 & 76 & 4 \\
\hline Torquas & 1 & 43.8 & 0.98 & 8.8 & 16.9 & 0.32 & 12.6 & 4.9 & 1.9 & 1.78 & 1.08 & 0.24 & 1.3 & 4.8 & 1980 & 1750 & 295 & 54 \\
\hline \multicolumn{19}{|c|}{ Standard Deviatio } \\
\hline Adirc & 5 & 0.3 & 0.08 & 0.4 & 0.2 & 0.01 & 0.7 & 0.2 & 0.2 & 0.09 & 0.12 & 00 & 0.1 & 0.9 & 83 & 59 & 65 & 4 \\
\hline & 14 & 1.4 & 0.25 & 1.1 & 0.9 & 0.04 & 0.8 & 0. & 0. & 0.13 & 0.69 & 0 & 0.3 & 1.1 & 5 & 49 & 74 & 7 \\
\hline & 2 & $\mathrm{NA}^{\mathrm{c}}$ & NA & NA & a & $\mathrm{N}$ & NA & $\mathrm{N}$ & $\mathrm{N}$ & NA & NA & 1 & NA & NA & NA & NA & NA & NA \\
\hline & 2 & NA & NA & NA & NA & NA & NA & NA & $\mathrm{N}$ & NA & NA & & NA & $\mathrm{N}$ & NA & NA & NA & NA \\
\hline In & 3 & 1.2 & 0.32 & 3.2 & 2.2 & 0.03 & 1.2 & 0.8 & 0.3 & 0.24 & 0.62 & 0.07 & 0.2 & 2.0 & 912 & 324 & 34 & 4 \\
\hline Assemblee subclass & 2 & NA & NA & NA & NA & NA & NA & NA & NA & NA & NA & NA & NA & NA & NA & NA & NA & NA \\
\hline & 4 & 1.1 & 0.05 & 0.6 & 1.4 & 0.03 & 0.2 & 0.2 & 0. & 0.10 & 0.06 & & 0.2 & 0. & & 61 & 20 & 7 \\
\hline & 7 & 1 & 0.30 & & 1 & 0.0 & 5. & 1 & 0 & 0.32 & 083 & 0 & 0.3 & 0 & 274 & 8 & 47 & 7 \\
\hline & 6 & 0. & 0.1 & 0 & 1.1 & & 1. & & 0 & 0.07 & 0.22 & & 0.2 & 0.9 & 31 & 54 & 139 & 22 \\
\hline Pesap & 7 & 1.1 & 0.13 & 0.4 & 0.7 & 0.03 & 0.3 & 0.3 & 0.2 & 0.24 & 0.22 & 0.06 & 0.5 & 0.9 & 129 & 92 & 52 & 16 \\
\hline Fuzzy Sr & 1 & NA & NA & NA & NA & NA & NA & NA & NA & NA & NA & NA & NA & NA & NA & NA & NA & NA \\
\hline & 4 & 1.7 & 0.12 & 0.3 & 1.2 & 0.01 & 0.6 & 0.2 & 0.2 & 0.01 & 0.05 & 0.01 & 0.0 & 0.1 & 629 & 315 & 5 & 3 \\
\hline Inno & 2 & NA & $\mathrm{NA}$ & $\mathrm{N}$ & $\mathrm{N}$ & $\mathrm{N} A$ & $\mathrm{~N}$ & $\mathrm{~N}$ & $\mathrm{~N}$ & NA & NA & NA & NA & NA & NA & NA & NA & NA \\
\hline & 2 & NA & $\mathrm{N}$ & NA & NA & $\mathrm{N}$ & NA & $\mathrm{N}$ & $\mathrm{N}$ & NA & NA & NA & NA & NA & NA & NA & JA & NA \\
\hline Good Q & 1 & NA & NA & NA & NA & NA & NA & NA & NA & NA & NA & NA & NA & NA & NA & NA & NA & NA \\
\hline & 4 & 1.6 & 0.07 & 0.4 & 0.8 & 0.01 & 0.3 & 1.0 & 0.1 & 0.03 & 0.02 & 0.01 & 0.0 & 2.2 & 25 & 129 & 0 & 15 \\
\hline 1 loce & 4 & 0. & 0.06 & & & 0.01 & 0 & & 0 & 0.22 & 0.06 & 0.02 & 0.1 & 0. & $4 /$ & 42 & 22 & 13 \\
\hline & 2 & $\mathrm{~N}$ & $\mathrm{~N}$ & $\mathrm{~N}$ & & $\mathrm{~N}$ & & & & & $\mathrm{~N}$ & & NA & & A & NA & NA & NA \\
\hline Torquas & 1 & NA & NA & NA & NA & NA & NA & NA & NA & NA & NA & NA & NA & NA & NA & NA & NA & NA \\
\hline
\end{tabular}

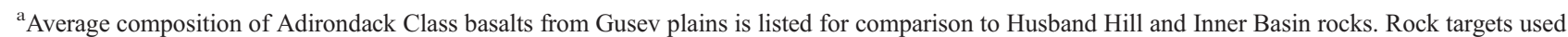
to define classes and subclasses are listed in Table $\mathrm{S} 1$ of the auxiliary material. Oxides are in wt \%, elements are in $\mathrm{mg} \mathrm{kg}^{-1}$.

${ }^{b}$ Number of APXS measurements in class.

${ }^{\mathrm{c}}$ Not applicable.

depleted in $\mathrm{Al}, \mathrm{Ca}$, and $\mathrm{Cr}$ compared to Adirondack Class basalts (Figure 4a). McSween et al. [2006b] classified the Irvine Class rocks as alkaline basalts.

\subsection{Independence: Low Fe Outcrop}

[27] Independence Class rocks are low $\mathrm{Fe}(3.8$ to $8.1 \mathrm{wt}$ $\% \mathrm{FeO}$ ) and relatively high $\mathrm{Si}$ and $\mathrm{Al}$ materials compared to other Columbia Hills rock classes. The Independence Class is divided into two subclasses, Independence and Assemblee. The distinguishing difference between the two subclasses is high $\mathrm{Cr}$ in Assemblee Subclass materials. Details on the chemistry and mineralogy of Independence Class materials are given by Clark et al. [2007].

\subsubsection{Independence Subclass}

[28] An unusual outcrop called Independence was analyzed by Spirit's instruments around sols $532-542$ just uphill from the Methuselah Outcrop on Cumberland Ridge. Several APXS integrations were preformed on undisturbed, RAT brushed, and scuffed (by the rover's wheel) surfaces of Independence. The most distinct geochemical marker for Independence was a low Fe content. The Fe content of the wheel-scuffed surface is the lowest (3.8 wt \%) of any rock or outcrop measured on Mars although a soil near Home Plate has an even lower Fe content (see section 7.3).

[29] Independence Subclass materials are enriched in Ti, $\mathrm{Al}, \mathrm{K}, \mathrm{P}$, and $\mathrm{Ni}$ and depleted in $\mathrm{Fe}, \mathrm{Mn}, \mathrm{Mg}, \mathrm{Ca}$, and $\mathrm{Cr}$ compared to Adirondack Class basalts (Figure 4c). One intriguing feature of Independence is a high $\mathrm{Al} / \mathrm{Si}$ ratio (see section 8.1). Clark et al. [2007] have shown geochemical evidence for a smectite-like phase in Independence, although there is no definitive mineralogical measurement that indicates smectite or an alteration phase with a composition similar to smectite.

\subsubsection{Assemblee Subclass}

[30] Spirit encountered the Voltaire Outcrop just uphill from Independence Outcrop. An irregularly shaped outcrop on the upper end of the Voltaire Outcrop called Assemblee contained low Fe, similar to Independence. The most striking difference between Independence and Assemblee was a very high $\mathrm{Cr}$ content $\left(2.9\right.$ wt $\left.\% \mathrm{Cr}_{2} \mathrm{O}_{3}\right)$ in the Assemblee Outcrop. Other noticeable differences between 
Table 6. Average Elemental Compositions and $\mathrm{Fe}^{3+} / \mathrm{Fe}_{\mathrm{T}}$ for Gusev Soil Classes ${ }^{\mathrm{a}}$

\begin{tabular}{|c|c|c|c|c|c|c|c|c|c|c|c|c|c|c|c|c|c|c|c|}
\hline \multirow[b]{2}{*}{ Soil Class } & \multirow[b]{2}{*}{$\mathrm{N}^{\mathrm{b}}$} & \multicolumn{13}{|c|}{ Oxides } & \multicolumn{4}{|c|}{ Elements } & \multirow[b]{2}{*}{$\mathrm{Fe}^{3+} / \mathrm{Fe}_{\mathrm{T}}$} \\
\hline & & $\mathrm{SiO}_{2}$ & $\mathrm{TiO}_{2}$ & $\mathrm{Al}_{2} \mathrm{O}_{3}$ & $\mathrm{FeO}$ & $\mathrm{MnO}$ & $\mathrm{MgO}$ & $\mathrm{CaO}$ & $\mathrm{Na}_{2} \mathrm{O}$ & $\mathrm{K}_{2} \mathrm{O}$ & $\mathrm{P}_{2} \mathrm{O}_{5}$ & $\mathrm{Cr}_{2} \mathrm{O}_{3}$ & $\mathrm{Cl}$ & $\mathrm{SO}_{3}$ & $\mathrm{Ni}$ & $\mathrm{Zn}$ & $\mathrm{Br}$ & $\mathrm{Ge}$ & \\
\hline \multicolumn{20}{|l|}{ Laguna } \\
\hline Panda subclass & 6 & 46.8 & 0.79 & 10.5 & 16.1 & 0.33 & 9.6 & 6.2 & 3.0 & 0.38 & 0.75 & 0.35 & 0.6 & 4.6 & 684 & 190 & 42 & 6 & 0.22 \\
\hline Liberty subclass & 11 & 46.6 & 0.85 & 10.4 & 15.9 & 0.33 & 8.7 & 6.3 & 3.1 & 0.47 & 0.89 & 0.35 & 0.6 & 5.4 & 443 & 262 & 40 & 10 & 0.28 \\
\hline Gobi subclass & 9 & 46.2 & 0.92 & 10.2 & 15.7 & 0.31 & 8.4 & 6.2 & 3.1 & 0.47 & 0.94 & 0.31 & 0.7 & 6.4 & 459 & 304 & 35 & 14 & 0.35 \\
\hline Boroughs subclass & 4 & 42.1 & 0.88 & 8.6 & 17.0 & 0.34 & 9.6 & 5.8 & 2.5 & 0.35 & 0.76 & 0.39 & 0.9 & 10.7 & 469 & 345 & 119 & 31 & 0.41 \\
\hline Dou & 2 & 46.7 & 1.55 & 12.1 & 12.1 & 0.22 & 7.8 & 7.1 & 3.0 & 0.51 & 2.15 & 0.17 & 0.7 & 5.7 & 279 & 130 & 92 & 2 & 0.41 \\
\hline aso Robles & 5 & 30.9 & 0.61 & 4.6 & 17.2 & 0.21 & 5. & 6.2 & 1. & 0.23 & 2.53 & 0.36 & 0.5 & 29.6 & 589 & 144 & 246 & 3 & 0.78 \\
\hline Gertrude Weise & 2 & 90.3 & 1.21 & 1.7 & 1.4 & 0.03 & 2.3 & 0.7 & 0.3 & 0.00 & 0.30 & 0.32 & 0.1 & 1.1 & 154 & 275 & 15 & 5 & 0.36 \\
\hline Eileen Dean & 2 & 49.5 & 0.50 & 6.1 & 16.1 & 0.24 & 15.8 & 3.8 & 1.4 & 0.42 & 0.67 & 0.53 & 1.7 & 3.1 & 717 & 1068 & 122 & 20 & 0.47 \\
\hline
\end{tabular}

\begin{tabular}{|c|c|c|c|c|c|c|c|c|c|c|c|c|c|c|c|c|c|c|c|}
\hline \multirow{2}{*}{\multicolumn{20}{|c|}{ Standard }} \\
\hline & & & & & & & & & & & & & & & & & & & \\
\hline Panda subclass & 6 & 0.7 & 0.17 & 0.6 & 0.6 & 0.02 & 1.0 & 0.2 & 0.4 & 0.05 & 0.05 & 0.06 & 0.2 & 1.3 & 207 & 84 & 17 & 8 & - \\
\hline Liberty subclass & 11 & 0.7 & 0.04 & 0.3 & 0.4 & 0.01 & 0.4 & 0.2 & 0.2 & 0.12 & 0.08 & 0.04 & 0.1 & 0.7 & 66 & 43 & 25 & 11 & - \\
\hline Gobi subclass & 9 & 0.8 & 0.11 & 0.6 & 0.6 & 0.02 & 0.2 & 0.2 & 0.2 & 0.02 & 0.07 & 0.03 & 0.1 & 0.9 & 95 & 77 & 11 & 10 & - \\
\hline Boroughs subclass & 4 & 2.3 & 0.02 & 0.6 & 0.4 & 0.01 & 0.7 & 0.1 & 0.1 & 0.01 & 0.05 & 0.03 & 0.2 & 2.5 & 28 & 94 & 76 & 8 & - \\
\hline Doubloon subclass & 2 & NA & NA & NA & NA & NA & NA & NA & NA & NA & NA & NA & NA & NA & NA & NA & NA & NA & - \\
\hline Paso Robles & 5 & 7.2 & 0.16 & 2.1 & 2.7 & 0.09 & 1.2 & 3.2 & 0.7 & 0.15 & 2.42 & 0.19 & 0.2 & 5.0 & 282 & 73 & 219 & 5 & - \\
\hline Gertrude Weise & 2 & NA & NA & NA & NA & NA & NA & NA & NA & NA & NA & NA & NA & NA & NA & NA & NA & NA & - \\
\hline Eileen Dean & 2 & NA & NA & NA & NA & NA & NA & NA & NA & NA & NA & NA & NA & NA & NA & NA & NA & NA & - \\
\hline
\end{tabular}

${ }^{a}$ Laguna Class has been broken down into subclasses based upon $\mathrm{Fe}^{3+} / \mathrm{Fe}_{\mathrm{T}}$. Soil targets used to define classes and subclasses are listed in Table S2. Oxides are in wt \%, elements are in $\mathrm{mg} \mathrm{kg}^{-1}$.

${ }^{\mathrm{b}}$ Number of APXS measurements in class.

${ }^{\mathrm{c}}$ Morris et al. [2008a].

Independence and Assemblee are enrichments of $\mathrm{Mn}, \mathrm{Mg}$, $\mathrm{K}$, and $\mathrm{Cl}$ and depletions in $\mathrm{Ti}, \mathrm{Ca}, \mathrm{Na}$, and $\mathrm{P}$ in Assemblee Subclass materials compared to Independence (Figure 4c).

\subsection{Descartes: Altered, Impact Materials}

[31] Descartes Class materials include several outcrops in the Voltaire complex just under the summit of Husband Hill. These outcrops have enrichments in Ti, $\mathrm{K}, \mathrm{P}, \mathrm{Cl}, \mathrm{S}, \mathrm{Ni}, \mathrm{Zn}$, and $\mathrm{Br}$ and depletions in $\mathrm{Fe}, \mathrm{Mn}, \mathrm{Ca}$, and $\mathrm{Cr}$ compared to Adirondack Class basalts (Figure 4c). Descartes materials have very similar enrichments and depletions compared to Independence Class materials; however, the depletion of $\mathrm{Fe}$ and $\mathrm{Mn}$ is much less in Descartes. Another notable difference is that the volatile elements $(\mathrm{S}, \mathrm{Cl}$, and $\mathrm{Br})$ are higher in Descartes Class materials.

[32] The Descartes materials are fairly altered according to the $\mathrm{Fe}$ mineralogy and $\mathrm{Fe}^{3+} / \mathrm{Fe}_{\mathrm{T}}$. The $\mathrm{Fe}$ mineralogy consists of npOx, pyroxene, magnetite, goethite, and hematite with $\mathrm{Fe}^{3+} / \mathrm{Fe}_{\mathrm{T}}$ ranging from 0.59 to 0.68 [Morris et al., 2008a]. The process that altered Descartes materials may be similar to the process(es) that altered Clovis and Watchtower Class materials. All three classes have relatively high contents of the volatile elements (i.e., $\mathrm{Cl}, \mathrm{S}$, and $\mathrm{Br}$ ) and are moderately to pervasively altered. Descartes materials may have been altered by solutions enriched in these volatile elements, but the water to rock ratio must have been low to prevent leaching or removal of soluble elements from the outcrop. Again, it is likely that acid sulfate weathering processes similar to the process described for Clovis Class materials may have altered Descartes materials [Ming et al., 2006].

[33] A large clast in one of the Voltaire outcrops called Bourgeoisie Chic has high Ti and P similar to Wishstone Class materials (Table 1). It appears that a Wishstone material clast was embedded in the Descartes material, possibly during an impact event. Such a relationship might suggest that the Descartes materials are melts of local materials that were produced during an impact [Arvidson et al., 2008].

\subsection{Algonquin Series: Mafic-Ultramafic Magmatic Sequence}

[34] Spirit conducted IDD campaigns on four outcrops (Larry's Bench, Seminole, Algonquin, and Comanche) located at different elevations while descending the southern flank of Haskin Ridge. These rocks have mafic to ultramafic compositions, and are olivine-rich and relatively unaltered on the basis of Mössbauer and Mini-TES results [Morris et al., 2008a; Ruff et al., 2006]. The rocks become progressively more mafic (increasing $\mathrm{Mg}$ and $\mathrm{Ni}$ concentrations) with descending elevation in the sequence Larry's Bench, Seminole, Algonquin, and Comanche Spur, suggesting a mafic-ultramafic sequence. Larry's Bench appears to be a mixture of a mafic component of the Algonquin series with Wishstone-like materials because it contains high $\mathrm{Ti}$ and $\mathrm{P}$, unlike the other Algonquin outcrops (Figure 2d). Geochemical and mineralogical characterization of the Algonquin series is provided by Mittlefehldt et al. [2006].

\subsection{Barnhill: Volcaniclastic Sediments}

[35] Home Plate is an $\sim 80 \mathrm{~m}$ wide quasi-circular layered plateau located in the Inner Basin (Figure 1). There are two distinct layered sequences; a lower coarse-grained layer of apparent volcaniclastic sediments and a fine-grained upper layer of apparent eolian reworked volcaniclastic sediments [Squyres et al., 2007]. Spirit analyzed the two layers on the northwest and southeast sides of Home Plate. Although the coarse- and fine-grained layers at each location are similar in chemical composition, there are significant geochemical and mineralogical differences between the northwest and southeast materials of Home Plate that warrant separation into the Barnhill and Pesapallo subclasses, respectively. Geochemical, mineralogical, and morphological properties of the Barnhill Subclass are described by Squyres et al. [2007]. 

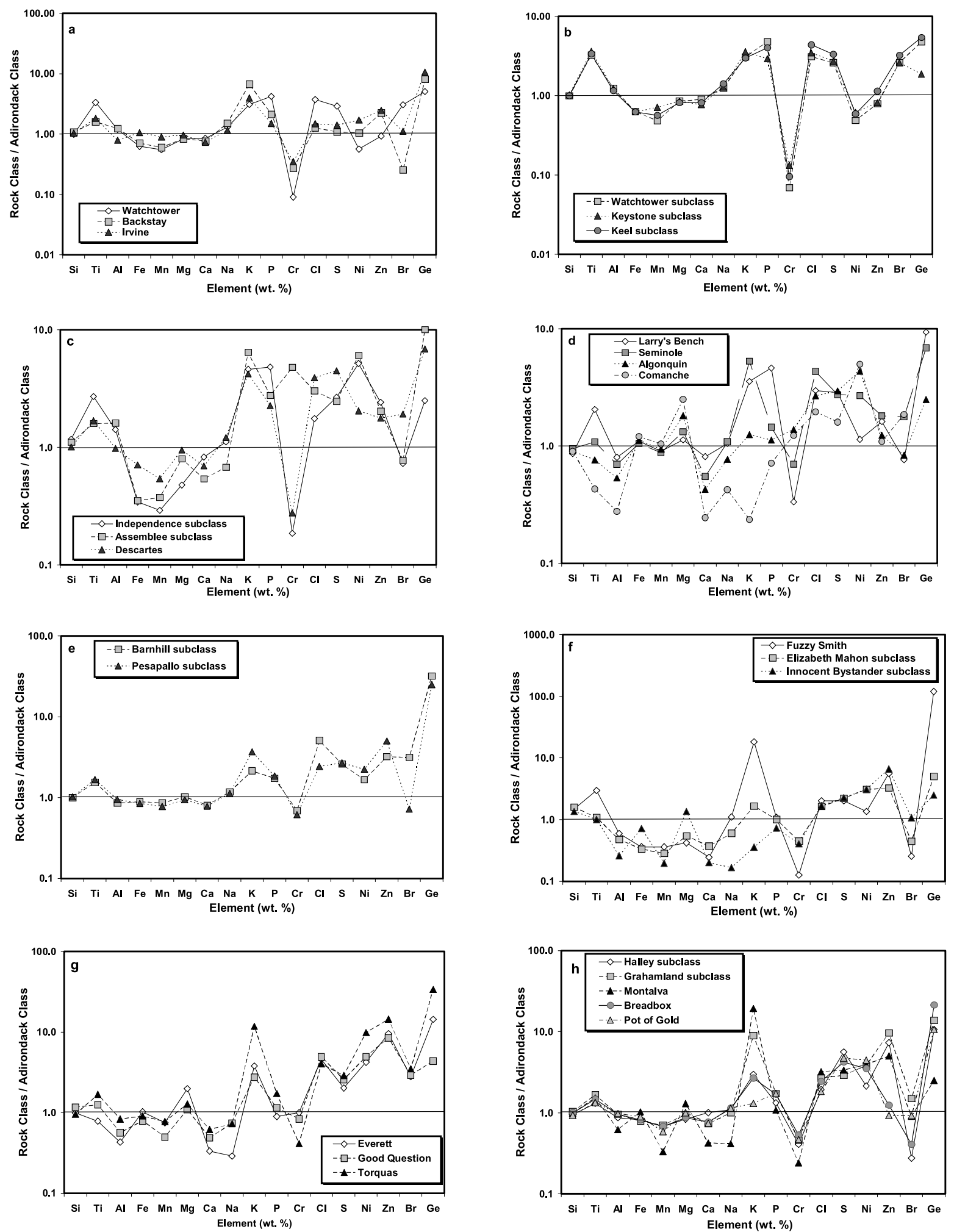

Figure 4. Elemental comparisons of rock classes and subclasses discovered on Husband Hill and the Inner Basin since sol 470. The data are normalized to the average composition of the Gusev plains Adirondack Class basalt: (a) Watchtower Class (high Ti and P and low $\mathrm{Cr}$ ) and alkaline basalt classes Backstay and Irvine; (b) Watchtower MB subclasses; (c) Independence and Descartes classes (low Fe); (d) Algonquin mafic-ultramafic magmatic series; (e) Barnhill Class volcaniclastic sediments; (f) Fuzzy Smith and Elizabeth Mahon classes (high Si, note that Elizabeth Mahon and Innocent Bystander subclasses are shown); (g) Everett, Good Question, and Torquas classes; and (h) Halley and Montalva classes (high hematite). Breadbox and Pot of Gold (Figure 4h) were encountered by Spirit early in the mission at the foot of West Spur in Hank's Hallow. 


\subsubsection{Barnhill Subclass}

[36] Barnhill Subclass is exposed in layered sequences on the northwest side of Home Plate. Clastic materials in the subclass are enriched in $\mathrm{Ti}, \mathrm{K}, \mathrm{P}, \mathrm{S}, \mathrm{Cl}, \mathrm{Ni}, \mathrm{Zn}$, and $\mathrm{Br}$ and depleted in $\mathrm{Ca}$ and $\mathrm{Cr}$ compared to Adirondack Class basalts (Figure $4 \mathrm{e})$. The $\mathrm{K}$ content $(0.3$ average wt $\%$ $\left.\mathrm{K}_{2} \mathrm{O}\right)$ along with $\mathrm{Na}\left(3.0\right.$ average wt $\left.\% \mathrm{Na}_{2} \mathrm{O}\right)$ suggests that the volcaniclastic sediments are derived from alkaline basalts similar to Irvine Class rocks [Squyres et al., 2007; Schmidt et al., 2008]. The high volatile component (i.e., Cl, $\mathrm{S}, \mathrm{Br}$ ) in Barnhill materials suggest that vapors or waters rich in these elements altered the sediments.

\subsubsection{Pesapallo Subclass}

[37] Pesapallo Subclass materials are exposed on the eastern side of Home Plate. The compositions of Barnhill and Pesapallo Subclass rocks are very similar, except that Pesapallo materials are enriched in $\mathrm{K}, \mathrm{Ni}$, and $\mathrm{Zn}$ and depleted in $\mathrm{Cl}$ and $\mathrm{Br}$ compared to Barnhill Subclass (Figure 4e). The average $\mathrm{Cl}$ content of Pesapallo is $1.0 \mathrm{wt} \%$ compared to $1.6 \mathrm{wt} \%$ in Barnhill. The relative depletion in $\mathrm{Cl}$ and $\mathrm{Br}$ in Pesapallo may suggest that the materials on the eastern side of Home Plate were not as extensively subjected to the same volatile-rich solutions as the sediments on the northwestern side. Fe mineralogy and $\mathrm{Fe}^{3+} / \mathrm{Fe}_{\mathrm{T}}$ also suggest a slightly greater degree of oxidation on the northwest side of Home Plate compared to the eastern side. Pesapallo Subclass materials have lower npOx contents and $\mathrm{Fe}^{3+} / \mathrm{Fe}_{\mathrm{T}}$ ratios than Barnhill materials [Morris et al., 2008a].

\subsection{Fuzzy Smith and Elizabeth Mahon: High Si Rocks} 6.7.1. Fuzzy Smith

[38] Spirit drove up on top of the northeastern side of Home Plate and encountered an unusual high Si float rock named Fuzzy Smith. The rock was enriched in $\mathrm{Si}, \mathrm{Ti}, \mathrm{K}, \mathrm{Zn}$, and $\mathrm{Ge}$ and depleted in $\mathrm{Al}, \mathrm{Fe}, \mathrm{Mn}, \mathrm{Mg}, \mathrm{Ca}, \mathrm{Cr}$, and $\mathrm{Br}$ compared to Adirondack basalts (Figure 4f). The $\mathrm{Si}$ and $\mathrm{Ti}$ compositions (68.4 wt \% $\mathrm{SiO}_{2}$ and 1.7 wt $\% \mathrm{TiO}_{2}$ ) are relatively high compared to other Gusev rocks. Another unique geochemical aspect of Fuzzy Smith is a high Ge content $\left(\sim 190 \mathrm{mg} \mathrm{kg}^{-1}\right)$. The rock also contains a unique Fe-bearing phase, which Squyres et al. [2007] suggested on the basis of Mössbauer parameters might be Fe-sulfide such as pyrite or marcasite. Acid sulfate leaching (i.e., bleaching) of a basalt might account for the high $\mathrm{Si}$ and Ti [Squyres et al., 2007]; however, the very high $\mathrm{K}$ and $\mathrm{Zn}$ complicate this interpretation. Potassium and $\mathrm{Zn}$ are highly mobile in acid sulfate systems and should have been leached from the rock along with $\mathrm{Fe}, \mathrm{Mn}, \mathrm{Mg}, \mathrm{Ca}$, etc. The presence of these two volatile elements might suggest their addition from a volcanic source subsequent to acid sulfate leaching [Heinrich et al., 1999; Kurosawa et al., 2003].

\subsubsection{Elizabeth Mahon}

[39] Elizabeth Mahon Class rocks (Elizabeth Mahon, Nancy Warren, Innocent Bystander, Norma Luker) consist of high $\mathrm{Si}$ rocks (61.8 to $72.8 \mathrm{wt} \% \mathrm{SiO}_{2}$ ) located in a local low called Eastern Valley between the southeastern edge of Home Plate and Mitcheltree Ridge. The high silica content has been attributed to an opaline silica phase as determined from Mini-TES data [Squyres et al., 2008; Wang et al., 2008]. These materials are geochemically similar to Fuzzy Smith in some aspects but very different in others. These high $\mathrm{Si}$ materials are enriched in $\mathrm{Si}, \mathrm{Ni}$, and $\mathrm{Zn}$ and depleted in $\mathrm{Al}, \mathrm{Fe}, \mathrm{Mn}, \mathrm{Ca}, \mathrm{Na}$ and $\mathrm{Cr}$ compared to Adirondack Class basalts (Figure 4f). The major differences between Fuzzy Smith and Elizabeth Mahon Class materials are enrichments in Elizabeth Mahon of $\mathrm{Mg}, \mathrm{Cr}$, and $\mathrm{Ni}$ and depletions of $\mathrm{Ti}, \mathrm{Al}, \mathrm{Mn}, \mathrm{Na}$, and $\mathrm{K}$ compared to Fuzzy Smith (Figure 4f). Also, Elizabeth Mahon materials have low $\mathrm{Ge}$ contents $\left(<10 \mathrm{mg} \mathrm{kg}^{-1}\right.$, i.e., below detection limit) compared to Fuzzy Smith.

[40] We have further divided Elizabeth Mahon Class rocks into the Elizabeth Mahon and Innocent Bystander subclasses (Figure 4f). Elizabeth Mahon Subclass materials (Elizabeth Mahon, Nancy Warren, Norma Luker) have higher $\mathrm{Si}\left(71.8\right.$ average wt $\left.\% \mathrm{SiO}_{2}\right)$ than Innocent Bystander Subclass $\left(62.4 \mathrm{wt} \% \mathrm{SiO}_{2}\right.$ ). Innocent Bystander is enriched in $\mathrm{Mg}(13.5 \mathrm{wt} \% \mathrm{MgO})$ and strongly depleted in $\mathrm{Na}$ and $\mathrm{K}$ $\left(0.4 \mathrm{wt} \% \mathrm{Na}_{2} \mathrm{O}\right.$ and $<0.1 \mathrm{wt} \% \mathrm{~K}_{2} \mathrm{O}$ ) compared to Elizabeth Mahon Subclass rocks.

\subsection{Everett, Good Question, and Torquas}

[41] Several rocks around Home Plate did not fit into any of the categories discussed above, so they are listed here as individual classes. Everett and Good Question Class rocks are located in Eastern Valley along the southeast rim of Home Plate, and Torquas lies near Mitcheltree Ridge (Figure 1). Two rocks are classified into the Everett Class: Everett and Slide. All three rock classes have similar elemental trends with respect to Adirondack Class basalts. They are enriched in $\mathrm{Mg}, \mathrm{K}, \mathrm{Cl}, \mathrm{Ni}, \mathrm{Zn}, \mathrm{Br}$, and $\mathrm{Ge}$ and depleted in $\mathrm{Al}, \mathrm{Mn}, \mathrm{Ca}$, and $\mathrm{Na}$ compared to Adirondack materials (Figure 4g). Torquas and Good Question are enriched in Ti, Good Question is enriched in Si, Everett is depleted in Ti, Torquas is enriched in P, and Everett is depleted in P compared to Adirondack basalts. There are however substantial differences between the three classes. Torquas has high $\mathrm{Ti}, \mathrm{K}, \mathrm{P}, \mathrm{Ni}$, and $\mathrm{Zn}$. Everett Class materials have low $\mathrm{Ti}, \mathrm{Al}, \mathrm{Ca}$, and $\mathrm{Na}$. Good Question is enriched in Si and depleted in Mn.

[42] The Fe mineralogy of these three classes is similar in containing very high amounts of magnetite along with npOx, pyroxene, olivine, and minor amounts of hematite [Morris et al., 2008a]. One major difference among these classes is their degree of alteration. Everett and Good Question materials are relatively unaltered to moderately altered with a $\mathrm{Fe}^{3+} / \mathrm{Fe}_{\mathrm{T}}$ of 0.46 to 0.51 ; whereas, Torquas appears to be moderately altered with a $\mathrm{Fe}^{3+} / \mathrm{Fe}_{\mathrm{T}}$ of 0.7 . Although the high magnetite content elevates the $\mathrm{Fe}^{3+} / \mathrm{Fe}_{\mathrm{T}}$, other $\mathrm{Fe}^{3+}$ phases (i.e., npOx and hematite) present in these materials do suggest some alteration.

[43] There are no clear geochemical or mineralogical indicators that suggest types of alteration or processes that might have occurred in these materials; however, the high $\mathrm{Cl}, \mathrm{Ni}, \mathrm{Zn}$, and $\mathrm{Br}$ may suggest alteration by hydrothermal waters or vapors [Schmidt et al., 2008].

\subsection{Halley and Montalva: Hematite-Rich Outcrops}

[44] Halley and Montalva materials lay on the Eastern Valley floor and in the Troll Outcrop, respectively [Arvidson et al., 2008]. Spirit spent a sizable portion of a Gusev winter at a location called Enderbyland. Spirit did not drive during this time and a number of APXS measurements were made on indurated material called Halley. Spirit traversed over Low Ridge on its journey back to Home Plate after the 


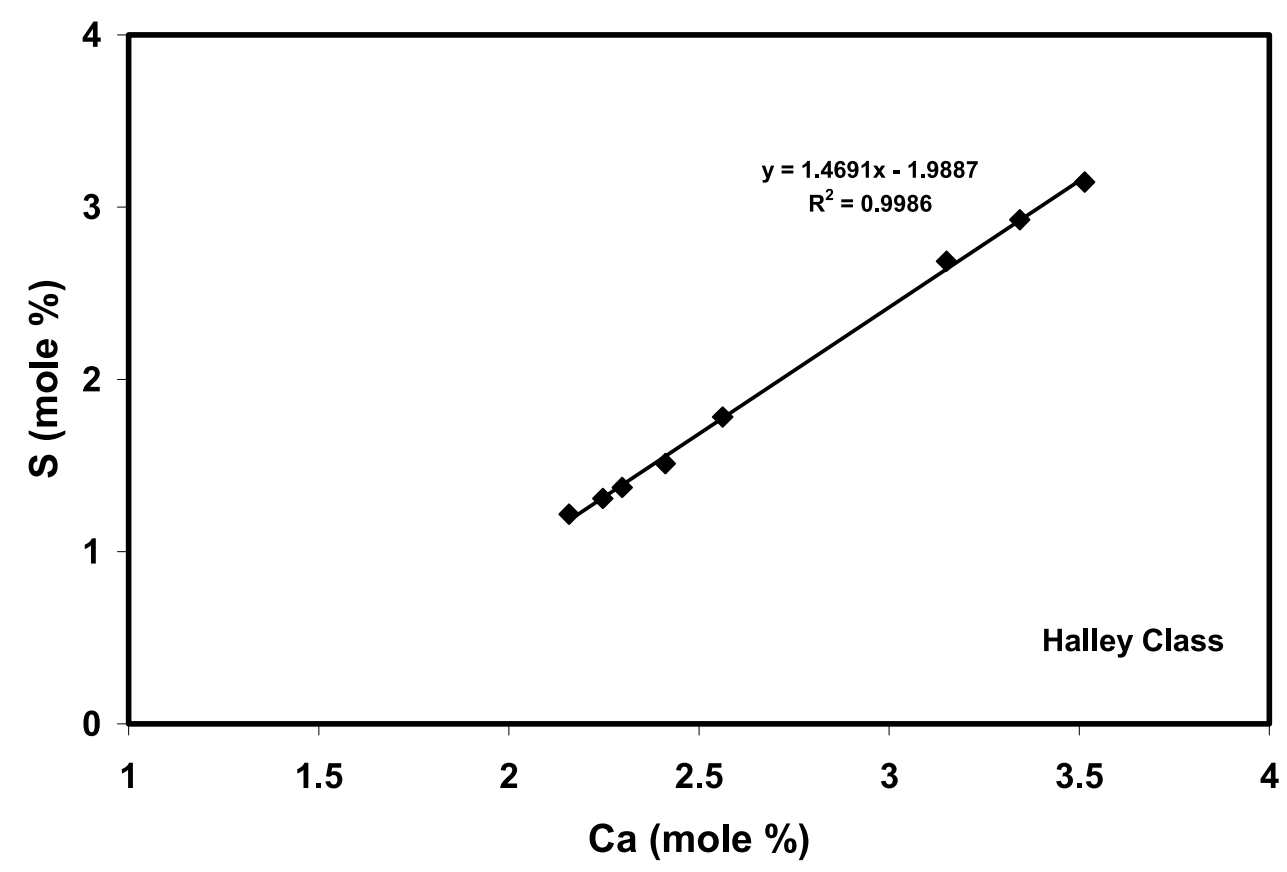

Figure 5. Sulfur and calcium correlation in Halley Class rocks suggests presence of a calcium sulfate phase in these hematite-rich materials.

winter campaign [Arvidson et al., 2008]. Several outcrops were encountered on or near Low Ridge including Graham Land and Montalva. The Enderbyland location where the Halley targets were encountered appears to be genetically linked to Low Ridge [Arvidson et al., 2008]. The Fe mineralogy in these materials is dominated by hematite [Morris et al., 2008a].

\subsubsection{Halley Class}

[45] The most distinctive feature of Halley Class materials is a high hematite content. Although the Halley Class materials are similar in chemistry there are several important differences; hence, the Halley Class was subdivided into two subclasses: Halley and Graham Land. These two subclasses have similar geochemical properties to Pot of Gold, Breadbox, and String of Pearls that were encountered early in the mission in Hank's Hollow near West Spur [Ming et al., 2006] so Pot of Gold, Breadbox, and String of Pearls [Gellert et al., 2006] are grouped into the Halley Subclass (Figure 4h).

\subsubsection{Halley Subclass}

[46] Halley Subclass materials are enriched in Ti, K, S, $\mathrm{Ni}$, and $\mathrm{Zn}$ and depleted in $\mathrm{Fe}, \mathrm{Mn}$ and $\mathrm{Cr}$ compared to Adirondack Class basalts (Figure 4h). The small size of the Halley target precluded "clean" APXS integrations on Halley material so several offsets of the APXS and MB were performed in an attempt to arrive at the mineralogy and chemistry of the target and minimize soil contamination. One of the Mössbauer integrations resulted in a target with nearly $70 \%$ of the $\mathrm{Fe}$ in the form of hematite with a $\mathrm{Fe}^{3+} / \mathrm{Fe}_{\mathrm{T}}$ of 0.88 [Morris et al., 2008a]. A Mars record for $\mathrm{Zn}\left(2270 \mathrm{mg} \mathrm{kg}^{-1}\right)$ was measured by the APXS in one of the Halley targets (A833_Enderbyland_Halley Center). One interesting elemental association is higher $\mathrm{Ca}$ and $\mathrm{S}$ in Halley Subclass rocks than in the Graham Land Subclass. An excellent elemental correlation between $\mathrm{Ca}$ and $\mathrm{S}$ suggests the presence of a Ca-sulfate in these materials (Figure 5).

\subsubsection{Graham Land Subclass}

[47] Graham Land Subclass materials have very similar geochemical properties to the Halley Subclass. The major difference between the subclasses is very high $\mathrm{K}$ in Graham Land materials $\left(1.25-1.67\right.$ wt $\left.\% \mathrm{~K}_{2} \mathrm{O}\right)$. Graham Land is also enriched in $\mathrm{P}, \mathrm{Cl}, \mathrm{Ni}, \mathrm{Zn}$, and $\mathrm{Br}$ and depleted in $\mathrm{Ca}$ and $\mathrm{S}$ compared to materials in the Halley Subclass (Figure 4h). The Fe mineralogy of Graham Land materials consists of mainly hematite. Materials in this subclass also appear to be pervasively altered as suggested by high $\mathrm{Fe}^{3+} / \mathrm{Fe}_{\mathrm{T}}$, which is similar to Halley [Morris et al., 2008a]. The morphological properties of Graham Land materials (friable, platy deposit of rounded uniformly, sand-sized grains), however, are different than the platy deposits of the Halley Subclass [Arvidson et al., 2008]. Volatile elements are relatively high in these materials, similar to some of the volatile compositions of materials around Home Plate suggesting that these outcrops were altered by solutions rich in these elements.

\subsubsection{Montalva}

[48] Montalva is a target located on the outcrop, Troll, in Eastern Valley, that lies stratigraphically below Graham Land [Arvidson et al., 2008]. The most striking geochemical feature of Montalva is very high $\mathrm{K}$. The APXS recorded the highest $\mathrm{K}$ content $(2.97 \mathrm{wt} \%)$ of any material analyzed in Gusev Crater. Montalva Class materials are enriched in Ti, $\mathrm{Mg}, \mathrm{K}, \mathrm{Cl}, \mathrm{S}, \mathrm{Ni}$, and $\mathrm{Zn}$ and depleted in $\mathrm{Al}, \mathrm{Mn}, \mathrm{Ca}, \mathrm{Na}$, and $\mathrm{Cr}$ compared to Adirondack basalts. This outcrop has similar Fe mineralogy to Halley; hematite is the most prominent Fe-bearing phase along with some magnetite [Morris et al., 2008a]. The material appears to be highly altered as indicated by a very high $\mathrm{Fe}^{3+} / \mathrm{Fe}_{\mathrm{T}}$ of 0.93 [Morris et al., 2008a]. 
[49] Montalva has quite different geochemical characteristics compared to Halley Class materials (see Figure 4h). One important characteristic is very low $\mathrm{Mn}(0.1 \mathrm{wt} \%$ $\mathrm{MnO}_{2}$ ) and relatively unchanged Fe compared to not only Halley but many other classes including Adirondack basalts. The very high $\mathrm{FeO} / \mathrm{MnO}$ oxide ratio (approx. 160 ) is one of the highest of all materials measured in Gusev Crater. Nearly all rocks (float and outcrop) and soils examined by the APXS in Gusev Crater have FeO/MnO oxide ratios of $45-55$. The only notable exceptions are a Clovis Class Outcrop called Wooly Patch and the Arad sulfur-rich soil (see section 7.2). The unique $\mathrm{FeO} / \mathrm{MnO}$ ratio in Montalva may represent alteration under different redox conditions compared to other rocks and outcrops in the Home Plate vicinity where the redox and $\mathrm{pH}$ solution conditions were such that Mn was mobilized and removed from the host rock and Fe remained unchanged [Ming et al., 2006].

\section{Soil Classes: Cumberland Ridge to Home Plate}

[50] Spirit's APXS measured a total of 25 soil surfaces on the trek over the top of Husband Hill and down into the Inner Basin. Soils do not vary in composition to the degree of the rocks encountered by Spirit; however, there were several very unique soils that contained very high $\mathrm{S}$, very high $\mathrm{Si}$, and mixtures of local rock into soil. The most prominent soil type in Gusev Crater is the Laguna Class soil. There are subtle differences in the APXS and MB compositions; hence, the Laguna Class soils have several subclasses that are mostly divided by MB Fe oxidation state and mineralogy [Morris et al., 2006, 2008a]. Paso Robles Class soils were first encountered by Spirit just downhill from Cumberland Ridge [Gellert et al., 2006]. Paso Robles has very high $\mathrm{S}$ and contains ferric sulfate [Ming et al., 2006; Morris et al., 2006]). Another unique type called Gertrude Weise was encountered by Spirit along the eastern side of Home Plate in Eastern Valley. Gertrude Weise has very high $\mathrm{Si}$ and $\mathrm{Ti}$. A third unique soil type called Eileen Dean was also discovered on the eastern side of Home Plate in Eastern Valley. Eileen Dean Class materials contain high $\mathrm{Mg}$ and magnetite. The new soil classes (Gertrude Weise and Eileen Dean) and the new members of Laguna and Paso Robles Class are discussed next.

\subsection{Laguna Class: Typical Gusev Crater Surface Soil}

[51] Laguna Class soils are the most common soils in Gusev Crater. These basaltic soils drape the Gusev plains and the Columbia Hills. Representative Laguna Class soils encountered by the journey from Cumberland Ridge to Home Plate are listed in Table 4 and their locations are shown in Figure 6.

[52] There are a few subtle mineralogical and chemical differences in the Laguna Class materials. Morris et al. [2006] have divided the Laguna Class into several subclasses based upon their Mineralogical Alteration Index (MAI) and S content. The Mineralogical Alteration Index (MAI) is based upon the percentage of total $\mathrm{Fe}\left(\mathrm{Fe}_{\mathrm{T}}\right)$ present as $\mathrm{Fe}^{3+}$ in alteration products [Morris et al., 2006]. Four subclasses were identified during the first 517 sols of Spirit's mission: (1) Panda Subclass (MAI $=17 \%, \mathrm{~S}=$ 0.53 moles $/ 24(\mathrm{O}+\mathrm{Cl})$ ), (2) Liberty Subclass (MAI $=22 \%$,
$\mathrm{S}=0.60$ moles $/ 24(\mathrm{O}+\mathrm{Cl})$ ), (3) Gobi Subclass (MAI = $26 \%, \mathrm{~S}=0.71 \mathrm{moles} / 24(\mathrm{O}+\mathrm{Cl}))$, and (4) Boroughs Subclass $(\mathrm{MAI}=31 \%, \mathrm{~S}=1.1 \mathrm{moles} / 24(\mathrm{O}+\mathrm{Cl}))$. The boundaries between Panda, Liberty, and Gobi subclasses are gradational rather than distinct.

[53] There are gradational elemental differences in $\mathrm{Cl}, \mathrm{S}$, and $\mathrm{Zn}$ that mirror the gradational changes in $\mathrm{Fe}$ mineralogy, i.e., MAI. Panda Subclass has the lowest composition of these mobile elements and Gobi has the highest (Figure 7a). These gradational differences likely reflect the amount of dust mixed with the local soils, i.e., more dust mixed in with the Gobi Subclass materials than the Panda and Liberty subclasses [Morris et al., 2006, 2008a].

[54] Doubloon is a soil subclass that has been added to the Laguna Class. Doubloon Subclass material was first encountered around sol 502 in a surface soil located near the base of the Methuselah Outcrop on Cumberland Ridge. Doubloon appears to be a mixture of Wishstone or Watchtower Class rock and Laguna Class materials. Doubloon is enriched in $\mathrm{Ti}, \mathrm{Al}$, and $\mathrm{P}$ that are all geochemical indicators for Wishstone Class materials. A second Doubloon Subclass soil was discovered in a soil target called Cliffhanger Hang Two located just under the summit of Husband Hill. The most notable difference between the Laguna subclasses is the Ti and P enrichments in Doubloon Subclass (Figure 7a). The influence of the nearby Wishstone and Watchtower Class rocks is very distinct as indicated by the enrichment of $\mathrm{Ti}, \mathrm{Al}, \mathrm{Ca}$, and $\mathrm{P}$ and depletion in $\mathrm{Fe}, \mathrm{Mn}, \mathrm{Cr}$, Ni, and $\mathrm{Zn}$ in Doubloon compared to the other Laguna Subclass soils. Boroughs Subclass soils have a distinct enrichment in $\mathrm{Cl}$, $\mathrm{Br}$, and $\mathrm{S}$ compared to the other subclasses (Figure 7a). These soils were exposed in trenches excavated by the rover's wheels out on the plains of Gusev Crater. The higher $\mathrm{S}, \mathrm{Cl}$, and $\mathrm{Br}$ and the apparent correlation of $\mathrm{Mg}$ with $\mathrm{S}$ in these soil trenches suggest that these elements have been mobilized by water and transported downward in the soil profile [Haskin et al., 2005; Wang et al., 2006].

[55] El Dorado, a member of the Panda Subclass, is a large ripple field located near the eastern slope of Husband Hill. The ripple field lies between Husband Hill and Home Plate (Figure 6). El Dorado materials consist of sand-sized basaltic grains, and it has the lowest levels of npOx for any Martian soil [Morris et al., 2008a]. The elemental composition of El Dorado is compared to the compositions of rock classes Adirondack (normalized) and Algonquin, Panda Subclass, and sand-sized ripple (Arena) materials in Figure $7 \mathrm{~b}$. Arena was a target on top of a ripple that was examined by the IDD instruments back on sol 41 out on the plains of Gusev Crater (note that sample Arena was named Crest Morning (sol 41) in the APXS nomenclature of Gellert et al. [2006]). El Dorado and Arena element trends are similar to Adirondack Class basalts. El Dorado is enriched in $\mathrm{Mg}, \mathrm{K}$, and $\mathrm{Ni}$ and depleted in $\mathrm{Fe}, \mathrm{Mn}, \mathrm{Ca}, \mathrm{Cr}$, and $\mathrm{Zn}$ compared to Adirondack. There are some subtle elemental differences between Arena and El Dorado. El Dorado is enriched in $\mathrm{Mg}$ and $\mathrm{Ni}$ and depleted in $\mathrm{Cr}$ and $\mathrm{Zn}$ compared to Arena. The chemistry of El Dorado suggests that there is likely more than one source region for the sand grains. The chemistry of El Dorado is a closer fit to Adirondack basalts than the nearby Algonquin Class materials (Figure 7b). The average composition of all Algonquin Class materials is plotted for comparison to El Dorado. The El Dorado 


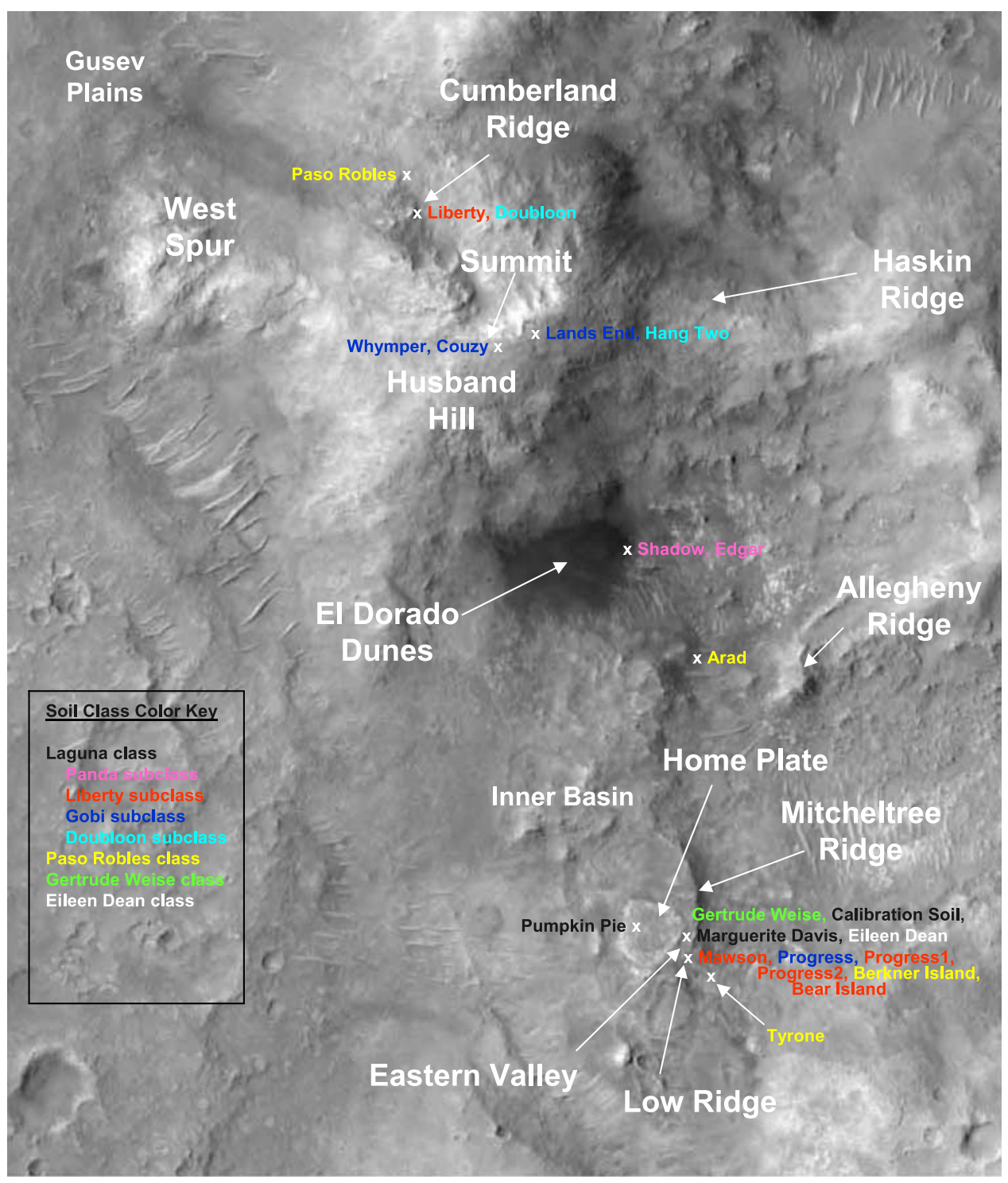

Figure 6. The approximate locations of APXS measurements for soil classes are shown on this image (see color key for soil classes on image). Soils marked as Laguna Class were not measured by the Mössbauer spectrometer and therefore the respective subclasses could not be determined. See Arvidson et al. [2008] for detailed descriptions of APXS sampling sites. (HiRISE PSP_001777_1655; image credit University of Arizona, JPL, and NASA.)

enrichments in $\mathrm{Mg}$ and $\mathrm{Ni}$ are chemical markers for the Algonquin Class; however, $\mathrm{Ti}, \mathrm{Al}, \mathrm{Mg}, \mathrm{Ca}$, and $\mathrm{Na}$ in $\mathrm{El}$ Dorado are more in line with Adirondack Class materials. It is likely that the source materials in the dune field are from local Algonquin Class materials, Adirondack basalts on the plains, and other undefined locations such as air fall dust.

\subsection{Paso Robles Class: High Sulfur and Ferric Sulfate-Rich Soil}

[56] Spirit first encountered a high $\mathrm{S}$ soil on the northwest flank of Husband Hill on sol 401. The soil called Paso Robles had a S content of $31.7 \mathrm{wt} \% \mathrm{SO}_{3}$, the highest $\mathrm{S}$ content measured on Mars up to that date [Gellert et al., 2006]. Paso Robles consisted of ferric sulfates, Mg-, Ca-, and other sulfates, Ca-phosphates, hematite, halite, allophane, and amorphous silica [Ming et al., 2006]. Spirit encountered a second high S soil (Arad) on sol 723 on the southeastern flank of Husband Hill near the El Dorado dune field (Figure 6). Arad set a new Mars record for $\mathrm{S}$ with a content of $35.1 \mathrm{wt} \% \mathrm{SO}_{3}$ (Table 1). Two additional high $\mathrm{S}$ soils (Berkner Island and Mount Darwin) were encountered near Tyrone [Arvidson et al., 2008]. These high S soils appear to be widespread around the Inner Basin [Yen et al., 2008; Wang et al., 2008].

[57] The major chemical indicator of Paso Robles Class soils is high S content; however, the different deposits have unique chemical signatures. Arad is strongly depleted in $\mathrm{Al}, \mathrm{Mn}, \mathrm{Ca}, \mathrm{Na}$, and $\mathrm{K}$ compared to the other locations (Figure 7c). Paso Robles (soil target) is highly enriched in P. The Berkner Island and Mount Darwin soil targets have very similar compositions because they are derived from the same material at Tyrone. The differences in chemistry 


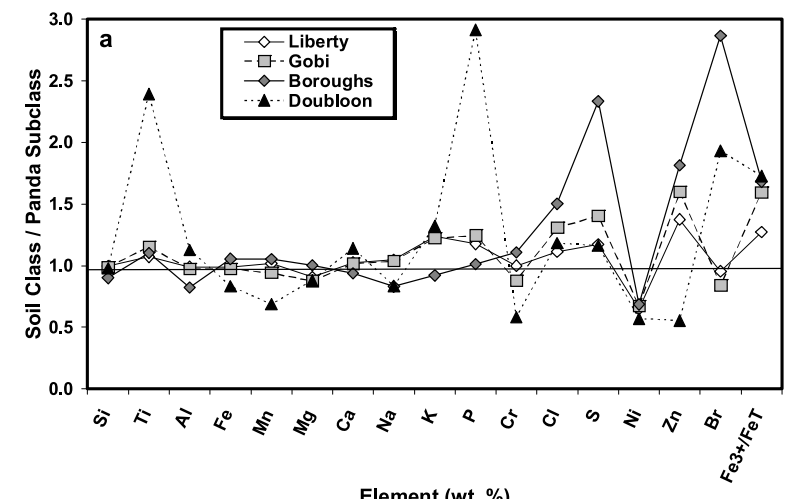

Element (wt. \%)

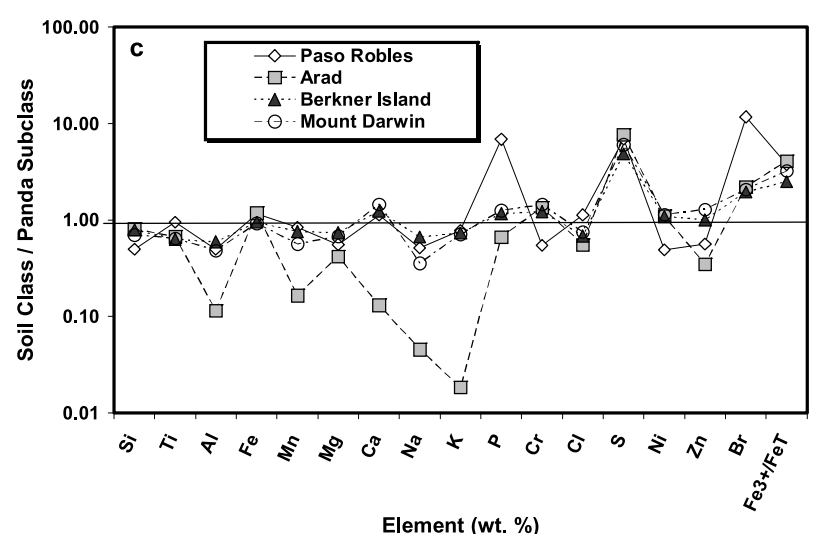

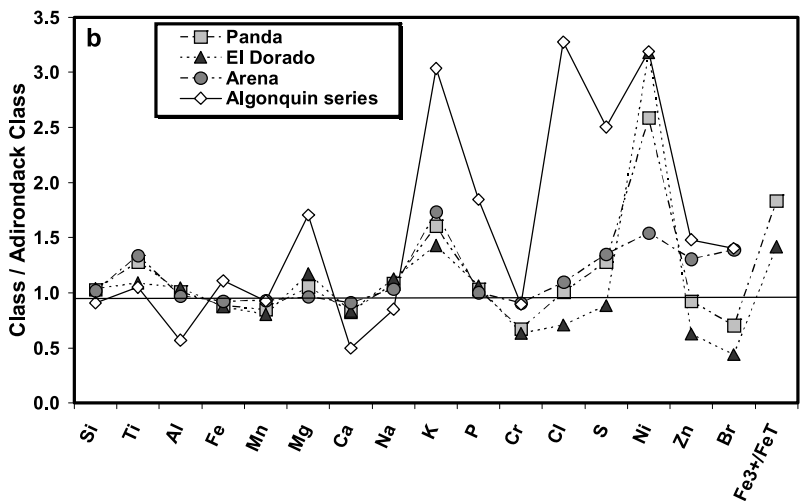

Element (wt. \%)

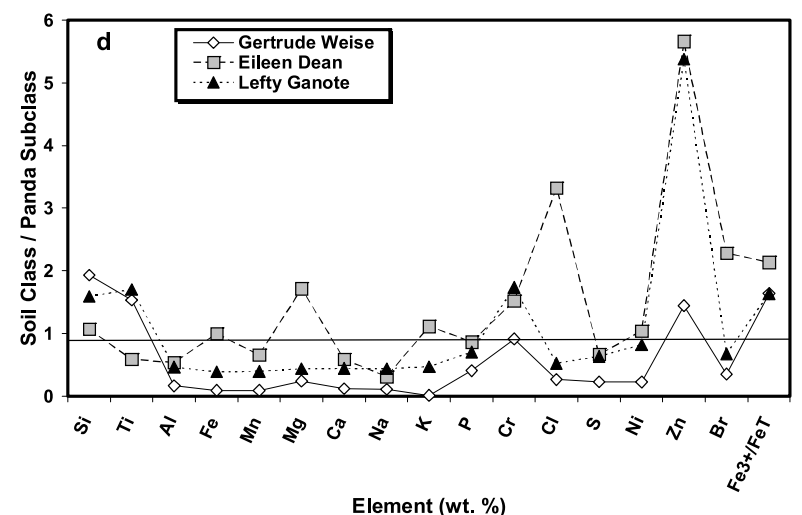

Element (wt. \%)

Figure 7. Elemental comparisons of soil classes and subclasses in Gusev Crater: (a) Laguna subclasses; (b) Panda Subclass compared to dune forms (El Dorado and Arena) and the Algonquin rock class; (c) Paso Robles Class (high S soils, note: individual soil targets shown); and (d) Gertrude Weise (high $\mathrm{Si}$ ) and Eileen Dean (high $\mathrm{Mg}$ ) classes. The data are normalized to the average composition of the Panda Subclass surface soils in Figures 7a, 7c, and 7d. Panda soils are the least altered soil class. The data are normalized to the average composition of the Gusev plains Adirondack basalt class in Figure $7 \mathrm{~b}$.

likely result from the location of the high $\mathrm{S}$ soil [see Yen et al., 2008]. For example, the high $\mathrm{P}$ and Fe in the Paso Robles soil target may reflect a host material that was altered by sulfuric acid solutions. It is reasonable to assume that $\mathrm{Fe}$ and $\mathrm{Mg}$ are the result of sulfuric acid solutions reacting with the basaltic source materials of the Peace Class material and the $\mathrm{P}$ and $\mathrm{Ca}$ may be the result of these acidic solutions reacting with a Wishstone-like source material [Ming et al., 2006]. Details on the chemistry and mineralogy of Paso Robles Class soils are described by Yen et al. [2008].

\subsection{Gertrude Weise: High Si Soil}

[58] Spirit encountered high Si soils in addition to high Si rocks in Eastern Valley near Home Plate [Squyres et al., 2008]. Gertrude Weise, a light-toned material exposed by the rover wheel, is located near the eastern rim of Home Plate. Spirit's APXS discovered a Mars record Si content of 90.5 wt $\% \mathrm{SiO}_{2}$ in the target Kenosha Comets of Gertrude Weise. Gertrude Weise is highly enriched in Si and Ti and depleted in all other elements except $\mathrm{Cr}$ compared to Adirondack Class basalts (Figure 7d). Mini-TES data indicate a nearly pure opaline silica phase [Squyres et al., 2008].
[59] Silicon, $\mathrm{Ti}$, and $\mathrm{Cr}$ are chemical indicators that this high $\mathrm{Si}$ soil is the residue that remained after acid sulfate leaching (i.e., bleaching) of a host material [Morris et al., 2000; Squyres et al., 2008]. The depletion of all the other elements suggests that these elements were removed by acidic solutions.

\subsection{Eileen Dean: High Mg and Magnetite Soil}

[60] Eileen Dean is a soil surface exposed by the rover's wheels during operations on the southeast side of Home Plate in Eastern Valley (Figure 6). The major geochemical and mineralogical properties of Eileen Dean are higher $\mathrm{Mg}$ and magnetite compositions than any other soil encountered in Gusev Crater [Morris et al., 2008a]. The chemical and mineralogical properties of Eileen Dean are nearly identical to Everett Class materials, suggesting that Eileen Dean may be nothing more than the disintegration of Everett Class materials (perhaps by the rover's wheels). Nonetheless, this unusual soil is enriched in $\mathrm{Mg}, \mathrm{Cl}, \mathrm{Zn}$, and $\mathrm{Br}$ and depleted in $\mathrm{Ti}, \mathrm{Al}, \mathrm{Mn}, \mathrm{Ca}, \mathrm{Na}$, and $\mathrm{P}$ compared to Panda Subclass soils (Figure 7d). Germanium was also enriched in Eileen Dean compared to a typical Laguna Class soil. The enrichments in $\mathrm{Ge}, \mathrm{Cl}$, and $\mathrm{Zn}$ may suggest that this soil was altered by hydrothermal solutions enriched in these elements, 


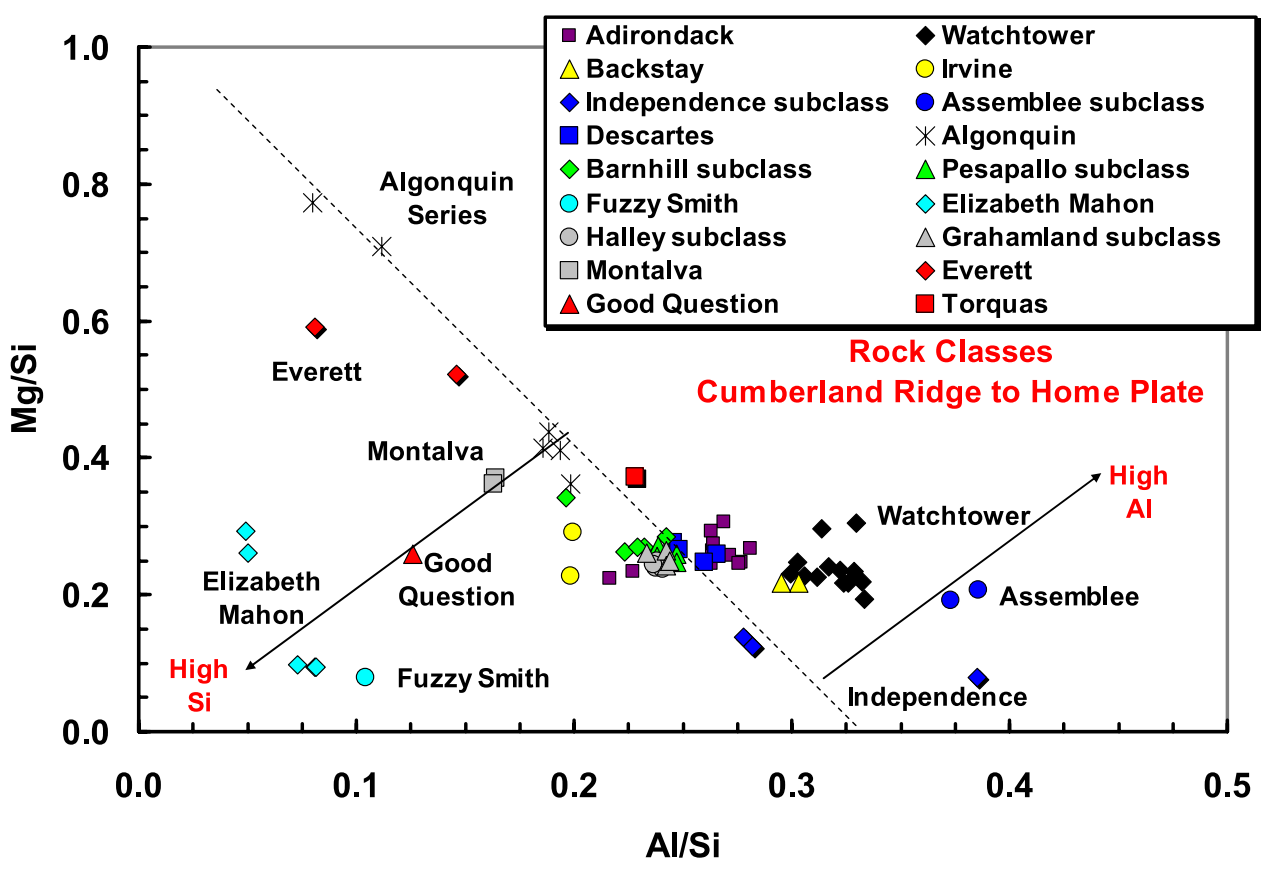

Figure 8. Elemental $\mathrm{Mg} / \mathrm{Si}$ versus $\mathrm{Al} / \mathrm{Si}$ for the Husband Hill and Inner Basin rock classes and subclasses. The dashed line represents the expected trend for igneous fractionation based upon the Martian meteorites. Several rock classes have trends that indicate enrichments in Si (e.g., Elizabeth Mahon, Fuzzy Smith, and Good Question) or enrichments in Al (e.g., Independence, Assemblee, and Watchtower).

similar to the solutions or vapors that have altered rocks such as Barnhill Subclass, and Torquas and Everett classes.

\section{Geochemical Relationships Between Rock Classes: Implications for Aqueous Processes}

[61] There are many geochemical associations and trends that highlight aqueous processes. We present the most prominent geochemical relationships next.

\subsection{High Si and Al Rocks: Leaching and/or Precipitation}

[62] Silicon and $\mathrm{Al}$ are two key elements that are used to map alteration in terrestrial environments [Nesbitt and Wilson, 1992]. Generally, $\mathrm{Si}$ is removed and $\mathrm{Al}$ is retained in weathering regimes in most terrestrial environments; however, in acid sulfate systems, which may be the primary alteration process in the Columbia Hills and Inner Basin, $\mathrm{Si}$ and $\mathrm{Al}$ may behave differently. $\mathrm{Si}$ is more resistant to mobilization and $\mathrm{Al}$ is more likely to weather out of a source material in acid sulfate systems [Ming et al., 2008]. These relationships between $\mathrm{Si}$ and $\mathrm{Al}$ complicate the interpretation of processes that might have acted upon them.

[63] There are some very distinct relationships between $\mathrm{Si}$ and $\mathrm{Al}$ in the Columbia Hills and Inner Basin. The high Si and $\mathrm{Al}$ rocks have already been described above, but these enrichments become very evident in Figure 8 where we plot elemental ratios of $\mathrm{Al} / \mathrm{Si}$ versus $\mathrm{Mg} / \mathrm{Si}$. The high $\mathrm{Si}$ rocks (i.e., Fuzzy Smith, Elizabeth Mahon, and Good Question classes) plot very distinctly toward the origin in Figure 8; this trend suggests the removal of $\mathrm{Al}$ and $\mathrm{Mg}$ from the protolith (assuming the protolith had a basaltic composition). This trend by itself suggests that either $\mathrm{Si}$ is being retained (or possibly added) and $\mathrm{Mg}$ and $\mathrm{Al}$ are being removed in host rock, or $\mathrm{Mg}$ and $\mathrm{Al}$ are being removed faster than $\mathrm{Si}$. This may suggest that these materials are being leached by acidic or acid sulfate solutions. High Ti in Fuzzy Smith further supports the notion that these materials have been "bleached" with acidic solutions. Titanium oxide is insoluble at low $\mathrm{pH}$ and is likely a residual phase from the host rock that has been altered under acidic conditions [Squyres et al., 2008]. However, there are several problems with advocating this process alone. Fuzzy Smith, for example, has very high $\mathrm{K}$, which is normally leached out during acid sulfate weathering. The identity of the $\mathrm{K}$ phase in Fuzzy Smith remains a mystery, so what process may have acted on this rock to retain such a high amount of $\mathrm{K}$ is unknown. One possible scenario for the $\mathrm{K}$ enrichment is a two-step process, where volcanic brines rich in volatile elements reacted with the rock, leaching most elements except $\mathrm{Si}$ and $\mathrm{Ti}$, followed by deposition of volatile elements associated with the volcanic brine during evaporation. This scenario is supported by the high Ge and $\mathrm{Zn}$ in Fuzzy Smith, volatile elements that may accompany hydrothermal solutions as described below in section 8.3.

[64] There are enrichments of $\mathrm{Al}$ in several rock classes including Independence and Watchtower classes. The enrichment in $\mathrm{Al}$ in Watchtower rocks likely results from a higher alkali feldspar content in these materials [Ming et al., 2006; Ruff et al., 2006]. However, the Al enrichment in Independence appears to be caused by alteration and weathering of mobile elements from the reaction front (i.e., open hydrologic system). All rocks measured by the APXS in Gusev Crater (sols $0-1368$ ) are plotted in Figure 9 on a traditional $\mathrm{Al}_{2} \mathrm{O}_{3}$ versus $\mathrm{FeO}+\mathrm{MgO}$ versus $\mathrm{CaO}+\mathrm{K}_{2} \mathrm{O}+$ $\mathrm{Na}_{2} \mathrm{O}$ ternary plot that is used to evaluate alteration in terrestrial systems [e.g., Nesbitt and Wilson, 1992]. The 


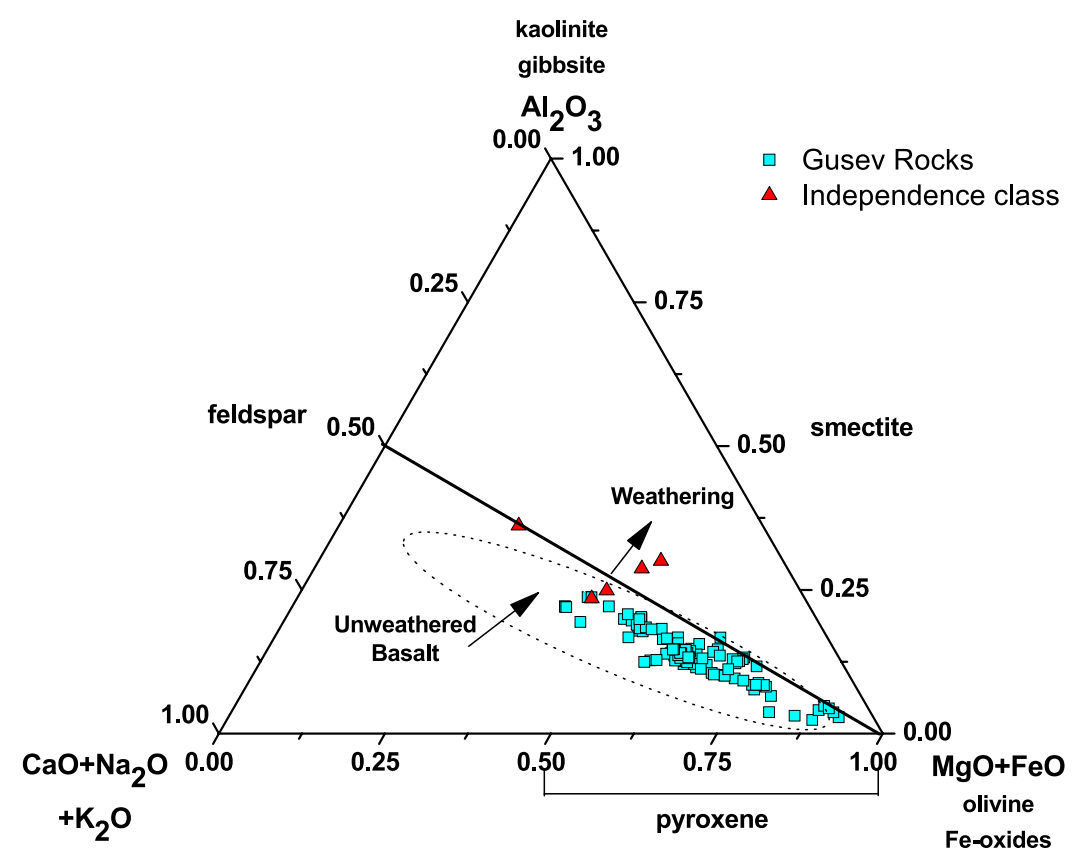

Figure 9. Compositional variations (molar) of Husband Hill and Inner Basin rocks shown in an $\mathrm{Al}_{2} \mathrm{O}_{3}$ versus $\mathrm{MgO}+\mathrm{FeO}$ versus $\mathrm{CaO}+\mathrm{Na}_{2} \mathrm{O}+\mathrm{K}_{2} \mathrm{O}$ ternary diagram. "Unaltered" basaltic materials will lie below the olivine-feldspar join in terrestrial systems (dashed field). Weathered basaltic materials where leaching has taken place will fall away from the olivine-feldspar join to more Al-rich composition (after Nesbitt and Wilson [1992]). Husband Hill and Inner Basin rocks fall within the trend expected for unaltered materials; however, the state of Fe in many of the rocks encountered by Spirit suggests they are altered. Independence Class rocks do have enrichments in $\mathrm{Al}$, suggesting that these materials have experienced leaching and alteration (see text).

rocks of Gusev Crater, with the exception of Independence, fall into molar oxide relationships that are expected for relatively unaltered basalts or basalts altered under isochemical conditions (i.e., closed hydrologic systems). Independence materials plot toward the smectite join on the diagram, a deviation from unweathered basalt that indicates enrichments in Al. Clark et al. [2007] have provided geochemical (but not mineralogical) evidence for the possibility of a smectite-like composition in Independence and the relationship shown in Figure 9 supports that hypothesis. The oxide relationships shown in Figure 9 do not, however, reflect an accurate picture of alteration in acid sulfate systems. Materials that have been altered by sulfuric acid weathering in terrestrial environments show very similar trends to unaltered tephra materials and the materials in the Columbia Hills [e.g., Hurowitz et al., 2006b; Ming et al., 2008].

[65] Although we cannot define the exact processes that altered the Columbia Hills materials, aqueous alteration clearly played a major role in their alteration. These trends in Si and Al suggest that rocks such as Fuzzy Smith and Elizabeth Mahon were leached by acidic fluids (solutions or vapors) and outcrops such as Independence experienced leaching under more neutral $\mathrm{pH}$ conditions in which $\mathrm{Al}$ is enriched and smectite or a smectite-like composition formed in an open hydrologic system [Ming et al., 2008].

\subsection{Phosphorus Mobility: Leaching and Precipitation of $\mathbf{P}$}

[66] Titanium and $\mathrm{P}$ are incompatible elements in ultramafic-mafic terrestrial igneous systems, and igneous frac- tionation will not greatly change the $\mathrm{P} / \mathrm{Ti}$ ratio of rocks. The $\mathrm{P} / \mathrm{Ti}$ ratio in Martian meteorites falls along a single trend, and we expect a similar trend for all Martian igneous systems [Longhi et al., 1992]. Four rock classes encountered by Spirit (Independence, Fuzzy Smith, Watchtower, and Wishstone (not shown)) have P/Ti ratios that fall off the Martian igneous line (dashed line in Figure 10). The P content of Watchtower and Wishstone Class materials is high for igneous systems and several possible scenarios have been previously presented to account for the high $\mathrm{P}$, such as metasomatism of silicate materials by hydrothermal solutions rich in $\mathrm{P}$ or acidic solutions dissolving $\mathrm{P}$ from source material and precipitating it in Wishstone and Watchtower materials [Ming et al., 2006].

[67] Independence Class rocks also lie well above the expected $\mathrm{P} /$ Ti ratio, suggesting enrichment in $\mathrm{P}$ (Figure 10). Clark et al. [2007] have suggested that Independence Class materials contain a smectite or smectite-like phase that has formed via aqueous processes. It is reasonable therefore to have a phosphate precipitate along with the smectite or smectite-like phase. The high $\mathrm{P}$ in Wishstone and Watchtower Class materials may be the source materials for the $\mathrm{P}$ that has precipitated in Independence Class materials.

[68] Fuzzy Smith, on the other hand, is enriched in Ti and depleted in $\mathrm{P}$ compared to the expected $\mathrm{P} / \mathrm{Ti}$ relationship in igneous materials (Figure 10). The leaching of Fuzzy Smith by acidic solutions has been pointed out earlier, so that $\mathrm{P}$ dissolution and leaching from Fuzzy Smith is to be expected. The alteration of Fuzzy Smith is very different than most materials that have been altered by aqueous 


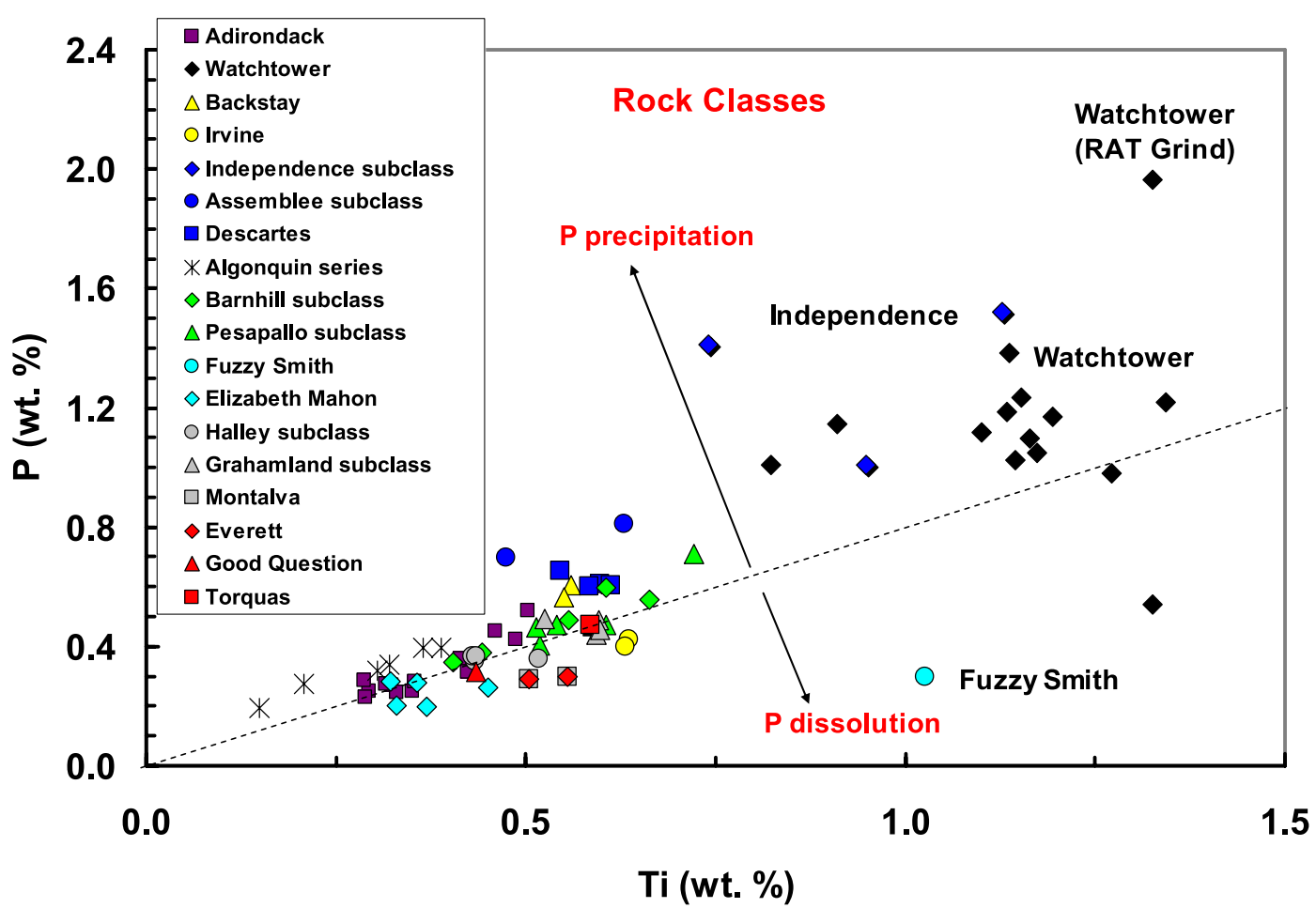

Figure 10. Phosphate mobility as indicated by $\mathrm{P}$ versus Ti for Husband Hill and Inner Basin rocks. The dashed line represents the slope of the line for the P/Ti ratio derived from Martian meteorites. Most of the rocks and outcrops have $\mathrm{P} / \mathrm{Ti}$ ratios consistent with igneous fractionation. Some materials have $\mathrm{P}$ contents that are far too high to be explained by Martian igneous processes and may represent materials that have experienced aqueous processes and the subsequent precipitation of $\mathrm{P}$ phases. On the other hand, Fuzzy Smith has a $\mathrm{P}$ content far too low to be explained by Martian igneous processes and indicates the leaching and removal of $P$.

processes because the elements most susceptible to attack by acidic solutions have been removed or leached away from the reaction front. The alteration of Fuzzy Smith suggests alteration in an open system, i.e., leaching, whereas most aqueous alteration encountered to date in Gusev Crater appears to be isochemical or in a closed system.

\subsection{Volatile Elements: Agents for the Alteration of Host Rocks}

[69] Enrichments in $\mathrm{Cl}, \mathrm{S}, \mathrm{Br}, \mathrm{Ge}, \mathrm{K}$, and $\mathrm{Zn}$ in some of the rocks and soils on Husband Hill and Inner Basin have implications for the style of aqueous alteration. We associate these elements with volcanic emissions or hydrothermal fluids associated with a volcanic source. They are also mobile in aqueous systems and consequently can be transported some distance and precipitate during an evaporation event or when a solution crosses a chemical or physical gradient (e.g., $\mathrm{P}$ and $\mathrm{T}$ ), resulting in the precipitation of discrete phases.

[70] Nickel and $\mathrm{Zn}$ have a positive correlation in most rocks in the Columbia Hills and Inner Basin with the exception of Algonquin and Independence Class rocks (Figure 11a). The high $\mathrm{Ni}$ in Algonquin materials is expected because of their mafic and ultramafic compositions. The high $\mathrm{Ni}$ in Independence may result from solution mobility of $\mathrm{Zn}$ (i.e., more likely to be removed from Independence) or possibly from Ni enrichments associated with impact events [Clark et al., 2007]. However, the Ni-Zn relationship for most of the rocks around Home Plate suggests these two elements are associated with a single process. They may be added through a hydrothermal process, such as from solutions associated with volcanic brine.

[71] Further evidence of alteration by hydrothermal solutions enriched in volatile elements is provided by enrichments of $\mathrm{Ge}$ and $\mathrm{Cl}$ in the same materials that exhibit $\mathrm{Zn}$ enrichments (Figures $11 \mathrm{~b}$ and $11 \mathrm{c}$ ). Germanium is a volatile siderophile metal that is sometimes associated with $\mathrm{Zn}$ and $\mathrm{Cl}$ in hydrothermal ore deposits [Bernstein, 1985]. For example, Zinc and $\mathrm{Cl}$ are enriched in some of the Barnhill Class outcrop materials; $\mathrm{Zn}$ is enriched in both the Barnhill and Pesapallo subclasses and only $\mathrm{Cl}$ is enriched in the Barnhill Subclass materials (section 6.6). The association of these volatile phases suggests a hydrothermal origin for these trace elements in the volcaniclastic sediments of Home Plate [Schmidt et al., 2008].

\section{Magnet Geochemistry}

[72] Both rovers contain a suite of magnets used to capture magnetic particles out of the atmosphere. The capture and filter magnets [Madsen et al., 2003] were periodically measured over the course of the mission by the APXS and the Mössbauer Spectrometers. The magnets 

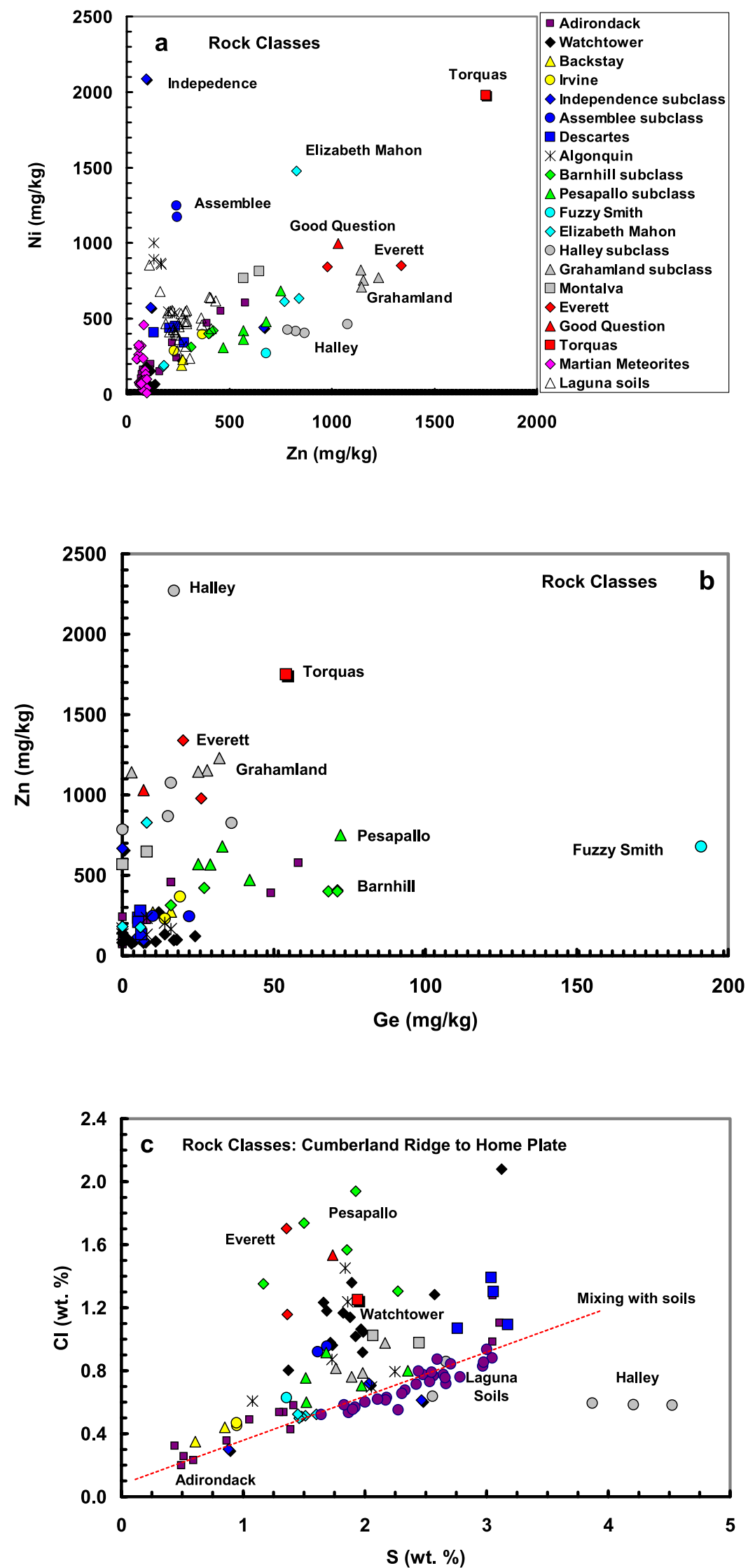

Figure 11. Elemental trends of the volatile elements in Husband Hill and Inner Basin rocks: (a) Ni versus $\mathrm{Zn}$; (b) $\mathrm{Zn}$ versus $\mathrm{Ge}$; and (c) $\mathrm{Cl}$ versus $\mathrm{S}$ (dotted line is the $\mathrm{Cl} / \mathrm{S}$ ratio common to Laguna Class soils). 


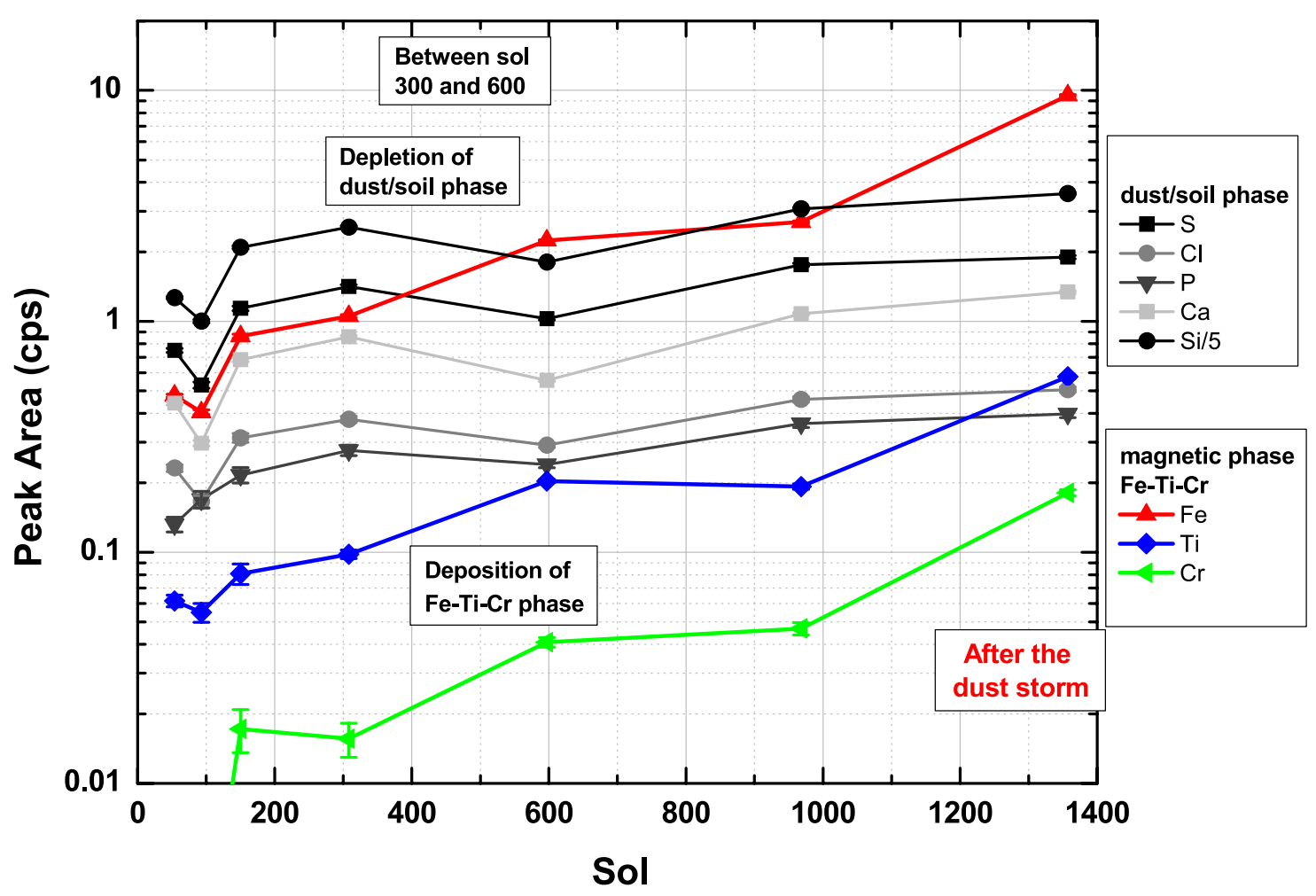

Figure 12. Composition trends of materials adhering to Spirit's capture magnet over the course of the mission. Variation of elemental composition over the mission timeline is recorded as total counts per second (peak area of the element's X-ray line in the spectrum). There is a discrete trend for Fe, $\mathrm{Ti}$, and $\mathrm{Cr}$ that suggests these elements are present in a single phase, in this case, as the strongly magnetic component of the Martian dust and soil.

are covered with an ultrapure Al metal sheet. Originally, the APXS was not intended to be the primary tool for characterizing the magnetic dust, so that the chemistry of the magnet cover was not a principle driver in the design of the capture magnet. Because aluminum metal has one of the largest responses (i.e., signal per abundance), APXS spectra of the capture magnet are dominated by an especially large $\mathrm{Al}$ signal early in the mission when the dust layer on the magnet was thin. The high Al signal rendered the detection of the low-energy X ray peaks of $\mathrm{Na}$ and $\mathrm{Mg}$ useless because of their overlaps with the Al peak tail in the spectra. In addition, micron-thin layers of material on the magnet complicated the analysis because of lack of sufficient interaction length of the radiation beam emitted by the APXS sources (small interaction volume). The usual APXS method is applicable to homogeneous materials with a thickness of $\geq 100 \mu \mathrm{m}$ (assumed density of $\sim 2.3 \mathrm{~g} \mathrm{~cm}^{-3}$ ) that can be considered as an infinite thickness for the applied radiation. The low-Z elements like $\mathrm{Na}$ contribute their signal from the topmost $\sim 3 \mu \mathrm{m}$ while the signal of higher- $Z$ elements like $\mathrm{Fe}$ is derived from up to $50 \mu \mathrm{m}$. Therefore, the $\mathrm{Na}$ signal contributes fully to the spectrum and the Fe signal is much less than what is actually present in a thin layer as encountered on the magnet early in the mission. For these reasons, the APXS spectra were used only to monitor the increase of peak signal for elements heavier than Si during the early part of the mission.

[73] Seven APXS measurements were made on Spirit's capture magnet since the beginning of the mission. The peak areas were very small at the beginning of the mission, indicating a thin dust/soil layer on the $\mathrm{Al}$ cover (Figure 12). Dust deposition on the magnet increased after sol 100 and the elemental trends become remarkably clear between sols 300 and 600. A dust cleaning event happened at the Spirit site around sol 420 that not only cleaned the solar panels but also removed the non magnetic phases from the capture magnet as indicated by a decrease in peak intensities for $\mathrm{Si}$, $\mathrm{Ca}$, and S. During this same time frame, the peak intensities for $\mathrm{Fe}, \mathrm{Ti}$, and $\mathrm{Cr}$ increased with consistent ratios between these elements, which indicated that those elements were constituents of the strongly magnetic phase. A large amount of material was collected by the capture magnet between sols 1000 and 1360. This enabled the use of the APXS calibration method for infinitely thick materials to determine the composition of the material adhering to the capture magnet (including $\mathrm{Na}$ and $\mathrm{Mg}$ ), even though there is still an enhancement ( $\sim 0.1$ of original intensity) of $\mathrm{Al}$ from the metal sheet covering the magnet (Table 1, Sol 1357).

[74] Iron, $\mathrm{Ti}$, and $\mathrm{Cr}$ are associated together as indicated by similar enrichment trends over the course of the mission (Figure 12). These elements constitute the strongly magnetic component(s) captured and permanently held by the magnet as shown above. Prior to the mission, the strongly magnetic phase was generally [Madsen et al., 1999; Hargraves et al., 1979] but not exclusively [Coey et al., 1990; Morris et al., 1993, 2001] thought to be maghemite. However, the APXS spectra are consistent with a Tibearing phase, implying an igneous origin (titanomagnetite 
Table 7. Composition of Soil and Dust Materials Adhering to the Capture Magnet on Sol $1357^{\mathrm{a}}$

\begin{tabular}{|c|c|c|c|c|c|c|c|c|c|c|c|c|c|c|c|c|}
\hline & \multicolumn{13}{|c|}{ Oxide (wt \%) } & \multicolumn{3}{|c|}{ Element $\left(\mathrm{mg} \mathrm{kg}^{-1}\right)$} \\
\hline & $\mathrm{SiO}_{2}$ & $\mathrm{TiO}_{2}$ & $\mathrm{Al}_{2} \mathrm{O}_{3}$ & $\mathrm{FeO}$ & $\mathrm{MnO}$ & $\mathrm{MgO}$ & $\mathrm{CaO}$ & $\mathrm{Na}_{2} \mathrm{O}$ & $\mathrm{K}_{2} \mathrm{O}$ & $\mathrm{P}_{2} \mathrm{O}_{5}$ & $\mathrm{Cr}_{2} \mathrm{O}_{3}$ & $\mathrm{Cl}$ & $\mathrm{SO}_{3}$ & $\mathrm{Ni}$ & $\mathrm{Zn}$ & $\mathrm{Br}$ \\
\hline $\begin{array}{l}\text { Sol } 1357 \text { capture magnet } \\
\text { Al corrected }\end{array}$ & 40.9 & 2.97 & 8.6 & 22.3 & 0.26 & 7.9 & 4.5 & 2.8 & 0.38 & 0.91 & 0.79 & 0.8 & 6.8 & 341 & 334 & 14 \\
\hline \multirow[t]{3}{*}{ Laguna soil average } & 46.3 & 0.84 & 10.1 & 15.9 & 0.32 & 8.6 & 6.3 & 3.1 & 0.37 & 0.86 & 0.33 & 0.7 & 6.0 & 492 & 262 & 43 \\
\hline & \multicolumn{16}{|c|}{ Element (mol) } \\
\hline & $\mathrm{Si}$ & $\mathrm{Ti}$ & $\mathrm{Al}$ & $\mathrm{Fe}$ & $\mathrm{Mn}$ & $\mathrm{Mg}$ & $\mathrm{Ca}$ & $\mathrm{Na}$ & $\mathrm{K}$ & $\mathrm{P}$ & $\mathrm{Cr}$ & $\mathrm{Cl}$ & $\mathrm{S}$ & $\mathrm{Ni}$ & $\mathrm{Zn}$ & $\mathrm{Br}$ \\
\hline $\begin{array}{l}\text { Capture magnet } \mathrm{Al} \text { corrected } \\
\text { (per } 24 \text { oxygens) }\end{array}$ & 5.930 & 0.324 & 1.468 & 2.706 & 0.032 & 1.698 & 0.698 & 0.787 & 0.071 & 0.112 & 0.091 & 0.207 & 0.745 & 0.005 & 0.004 & 0.000 \\
\hline $\begin{array}{l}\text { Laguna soil average } \\
\text { (assume } 92 \% \text { soil) }\end{array}$ & 5.930 & 0.083 & 1.503 & 1.745 & 0.035 & 1.622 & 0.882 & 0.750 & 0.075 & 0.092 & 0.033 & 0.171 & 0.630 & 0.006 & 0.004 & 0.000 \\
\hline $\begin{array}{l}\text { Difference } \\
\mathrm{Mg}, \mathrm{Na} \text { chlorides, sulfates }\end{array}$ & 0.000 & 0.241 & -0.035 & 0.962 & -0.003 & $\begin{array}{l}0.076 \\
0.076\end{array}$ & -0.184 & $\begin{array}{l}0.036 \\
0.036\end{array}$ & -0.004 & 0.020 & 0.058 & $\begin{array}{l}0.036 \\
0.036\end{array}$ & $\begin{array}{l}0.115 \\
0.115\end{array}$ & -0.001 & 0.001 & 0.000 \\
\hline $\begin{array}{l}(\mathrm{Fe}, \mathrm{Ti}, \mathrm{Cr})_{3} \mathrm{O}_{4} \\
\text { Inferred soil variation }\end{array}$ & & 0.241 & -0.035 & 0.962 & -0.003 & & -0.184 & & -0.004 & 0.020 & 0.058 & & & -0.001 & 0.001 & 0.000 \\
\hline
\end{tabular}

${ }^{\mathrm{a}}$ Composition listed here has been corrected for $\mathrm{Al}$ contributed by the $\mathrm{Al}$ metal cover on the magnet (see text). The average composition for Laguna Class soils is shown for comparison. The $\mathrm{Fe}$, $\mathrm{Ti}$, and $\mathrm{Cr}$ content in the strongly magnetic phase adhering to the capture magnet was estimated by subtracting out the contribution from a soil (assuming a composition similar to Laguna soils) and chlorides and sulfates from the dust (assuming Mg and $\mathrm{Na}$ chlorides and sulfates). The small positive and negative compositions remaining after extracting the $\mathrm{Fe}, \mathrm{Ti}$, and $\mathrm{Cr}$ in the magnetic phase are assumed to be due to either a variation in the soil composition or in the error of the measurement.

and/or its oxidized equivalent titanomaghemite). Mössbauer spectra of surface targets (rock and soil) and the capture magnet [Morris et al., 2006, 2008a; Madsen et al., 2008] together with the Ti and $\mathrm{Cr}$ from APXS firmly establish Tibearing magnetite as the strongly magnetic phase at Gusev Crater. The other elements (i.e., $\mathrm{Si}, \mathrm{Ca}, \mathrm{P}, \mathrm{Cl}$, and $\mathrm{S}$ ) shown in Figure 12 are associated together as suggested by the similar enrichment trends over the course of the mission. These phases likely represent the composition of the soil/dust adhering to the magnet and it was this phase that was removed from the surface of the magnet by the dust cleaning event around sol 420. There is a small trend in these elements that indicates the soil component is not thick enough to accommodate the APXS calibration. $\mathrm{Si}, \mathrm{Na}$, and $\mathrm{Mg}$ trend together, but the $\mathrm{Ca}$ trend is $30 \%$ lower than the increase of $\mathrm{Si}$, $\mathrm{Na}$, and $\mathrm{Mg}$ over the course of the mission. This decrease may result from a dust layer that is not thick enough to produce a full signal for the amount of $\mathrm{Ca}$ present. This unknown thickness of the nonmagnetic soil like phase poses the highest uncertainty for estimating the amount of $\mathrm{Ti}, \mathrm{Cr}$ and especially Fe in soil that has to be corrected for in the extraction of the titanomagnetite composition. If the trend in decreasing $\mathrm{Ca}$ is due to thin soil, the amount subtracted is overestimated.

[75] The composition of the material collected by the capture magnet can be corrected for the Al contribution from the magnet $\mathrm{Al}$ cover layer by normalizing $\mathrm{Al}$ to $\mathrm{Mg}$ and then correcting the absorption matrix (without the excess $\mathrm{Al}$ ). Normalizing $\mathrm{Al}$ to $\mathrm{Mg}$ is a reasonable assumption because the two elements are nearly equal in a typical Gusev soil, i.e., Laguna Class soils (Table 6). The Al-corrected composition of materials adhering to the capture magnet on sol 1357 and the average soil composition of Laguna Class soils are listed in Table 7. The most notable differences between the two targets are enrichments in $\mathrm{Ti}$ and Fe and depletion in Si. The capture magnet materials also have enrichments in $\mathrm{Cr}, \mathrm{P}, \mathrm{Cl}, \mathrm{S}$ and $\mathrm{Zn}$ and depletions in $\mathrm{Al}, \mathrm{Mg}, \mathrm{Ca}$, and $\mathrm{Na}$ compared to the surface soil composition.

[76] The composition of the strongly magnetic phase can be estimated by extracting a Laguna soil surface composition from the composition of the material adhering to the magnet. The assumption here is that the soil surface is similar to the material that is not strongly magnetic and that the amount of soil material adhering to the magnet can be estimated by total $\mathrm{Si}$ content. The magnet has collected about $92 \%$ soil-like material based upon these assumptions (Table 7). Silicon, Al, Mn, K, P, Ni, Zn, and Br have been removed from the strongly magnetic composition as indicated by compositions very near zero remaining after extracting the soil composition. Thus these elements may be ignored for determining the magnetic phases. Slight enrichments of $\mathrm{Mg}, \mathrm{Na}, \mathrm{P}, \mathrm{Cl}$, and $\mathrm{S}$ over a typical soil suggest that the dust has been enriched in these elements, possibly indicating the addition of $\mathrm{Mg}$ and $\mathrm{Na}$ sulfates, chlorides, and phosphates. The origin of the rather large depletion in $\mathrm{Ca}$ after the typical soil composition is extracted from the magnet-adhering material is not clear and is ignored for the sake of estimating the composition of the strongly magnetic phase. As discussed above, Ca signal may be strongly affected by dust thickness. The remaining $\mathrm{Ti}, \mathrm{Fe}$, and $\mathrm{Cr}$ are assumed to be present in magnetite with a composition of $\left(\mathrm{Fe}^{3+} \mathrm{Fe}^{2+}\right)_{2.3} \mathrm{Ti}_{0.6} \mathrm{Cr}_{0.1} \mathrm{O}_{4}$. Mössbauer parameters for the magnetite sextet in Gusev soils suggest that it is nonstoichiometric owing to substitutional impurity [Morris et al., 2006]. Although the trends show that Ti, Fe, and $\mathrm{Cr}$ compose the strongly magnetic phase, the substitution of $\mathrm{Al}$ into the structure cannot be ruled out because of the complexity of measuring the $\mathrm{Al}$ content with interference from the $\mathrm{Al}$ cover over the magnet. It is reasonable to assume that the Ti-bearing magnetite has an $\mathrm{Al}$ composition of 3 wt $\% \mathrm{Al}_{2} \mathrm{O}_{3}$ [Morris et al., 2008b]. The $\mathrm{Al}$ corrected composition of the magnetite is $\left(\mathrm{Fe}^{3+} \mathrm{Fe}^{2+}\right)_{2.24} \mathrm{Ti}_{0.56} \mathrm{Al}_{0.07}$ $\mathrm{Cr}_{0.13} \mathrm{O}_{4}$. Although several assumptions were used to derive the composition of the material adhering to the capture magnet, this new APXS data set, plus the Mössbauer results suggests that the strongly magnetic phase in the Martian soil and dust is titanomagnetite.

\section{Conclusions}

[77] A geochemically diverse suite of rocks and soils was analyzed by the APXS during Spirit's journey over 
Husband Hill and down into the Inner Basin from sol 470 to 1368 . The diversity may be attributed to a combination of processes including igneous fractionation (e.g., Algonquin magmatic sequence), aqueous alteration (e.g., Independence and Fuzzy Smith classes), impact (e.g., Descartes Class), and volcanic processes (e.g., Barnhill Class). There are several very clear geochemical indicators that support these processes. The trend in mafic materials uphill and becoming progressively more ultramafic downhill support a magmatic sequence for the Algonquin rocks and outcrops on the south side of Haskin Ridge. Nearly all materials encountered by Spirit experienced some degree of aqueous alteration; however, several materials have geochemical properties that indicate extensive alteration by water. The rock Fuzzy Smith and the soils Kenosha Comets and Lefty Ganote exhibit geochemical signatures of very high $\mathrm{Si}$ and $\mathrm{Ti}$ enrichments and depletions in most other elements, suggesting extensive aqueous leaching of these materials probably by acid sulfate solutions. On the other hand, Independence Class rocks have enrichments of $\mathrm{Al}$ and $\mathrm{P}$ that are indicative of leaching with precipitation of secondary smectite-like phases and phosphates. The most notable case of elemental mobilization and reprecipitation is the Paso Robles Class soils. These very high $\mathrm{S}$ soils are enriched in elements that are mobilized by acidic solutions and their compositions likely reflect host materials where those acidic solutions leached the host's elements and transported them to the soil deposit (e.g., P mobilized from Wishstone-like materials and precipitated in Paso Robles soil).

[78] Geochemical indicators of impact processes are not as evident as indicators for aqueous processes. The most notable geochemical indicator for impact processes is enrichment in $\mathrm{Ni}$; however, igneous fractionation and aqueous processes complicate the interpretation of $\mathrm{Ni}$ enrichments from meteoritic inputs. Descartes Class materials appear to be impact derived not necessarily by geochemical signatures, but by the fact that clasts of different materials (i.e., Wishstone) are embedded in a matrix of materials that are geochemically similar to Independence Class materials. Slight enrichment in $\mathrm{Ni}$ and depletion in $\mathrm{Mg}$ and $\mathrm{Fe}$ of Descartes materials compared to typical Adirondack basalts may indicate $\mathrm{Ni}$ enrichment from a meteoritic source, although aqueous processes cannot be ignored. Volcanic and hydrothermal processes appear to be very prominent in the Inner Basin and particularly for Home Plate materials. The association of volatile elements $(\mathrm{K}, \mathrm{Zn}, \mathrm{Cl}$, and $\mathrm{Ge})$ with Home Plate sediments and materials around Home Plate suggests that fluids rich in these volatile elements interacted with and altered these materials. These elements are generally associated with hydrothermal solutions that move through a host rock or ore body. The morphological characteristics of Home Plate suggest that the sediments are of volcaniclastic origin [Squyres et al., 2007; Schmidt et al., 2008].

[79] Eolian processes are very evident on Mars as indicated from morphological evidence of dunes, bed forms, and ripples. The uniform composition of surface materials also suggests homogenization of surface materials by the wind [Gellert et al., 2004]. Spirit's capture magnet captured a strongly magnetic phase in the dust-blown materials. Previous Mössbauer analysis of the capture magnet sug- gested the presence of magnetite [Goetz et al., 2005], and magnetite is very common Gusev Crater materials [Morris et al., 2006, 2008a]. New chemical data presented here for the capture magnet further refines the chemistry of the strongly magnetic phase as a Ti- and Cr-containing magnetite, although the presence of other elements such as $\mathrm{Al}$ cannot be ruled out as constituents of the magnetite. The stoichiometry of the magnetite based upon this new chemical data suggests that the strongly magnetic phase in Martian dust and soils is titanomagnetite.

[80] The APXS on Spirit continues to function nominally and there are no changes in the calibration of the instrument over the first 1368 sols of the mission. The geochemical diversity of materials in the Columbia Hills and the inner basin over $\sim 20 \mathrm{~m}$ is remarkable and new geochemical relationships will no doubt be encountered by Spirit as long as the rover continues to journey across the Martian landscape.

[81] Acknowledgments. We thank the members of the MER project who enable daily science observations at the Spirit landing site. The work described in this paper was conducted at the Jet Propulsion Laboratory, California Institute of Technology, under a contract with NASA. D. W. M. and R. V. M. acknowledge support of the NASA Mars Fundamental Research Program and the NASA Johnson Space Center. R. G. acknowledges support from the Canadian Space Agency. C. S. acknowledges support by an appointment to the NASA Postdoctoral Program at the Johnson Space Center, administered by Oak Ridge Associated Universities through a contract with NASA. We thank David Vaniman and an anonymous reviewer for detailed reviews.

\section{References}

Arvidson, R. E., et al. (2004), Localization and physical properties experiments conducted by Spirit at Gusev Crater, Science, 305, 821-824, doi:10.1126/science.1099922.

Arvidson, R. E., et al. (2006), Overview of the Spirit Mars Exploration Rover Mission to Gusev Crater: Landing site to Backstay Rock in the Columbia Hills, J. Geophys. Res., 111, E02S01, doi:10.1029/ 2005 JE002499.

Arvidson, R. E., et al. (2008), Spirit Mars Rover Mission to Columbia Hills, Gusev Crater: Mission overview and selected results from the Cumberland Ridge to Home Plate, J. Geophys. Res., 113, E12S33, doi:10.1029/ 2008JE003183.

Bernstein, L. R. (1985), Germanium geochemistry and mineralogy, Geochim. Cosmochim. Acta, 49, 2409-2422, doi:10.1016/00167037(85)90241-8.

Clark, B. C., et al. (2007), Evidence for montmorillonite or its compositional equivalent in Columbia Hills, Mars, J. Geophys. Res., 112, E06S01, doi:10.1029/2006JE002756.

Coey, J. M. D., S. Morup, M. B. Madsen, and J. M. Knudsen (1990), Titanomaghemite in magnetic soils on Earth and Mars, J. Geophys. Res., 95, 14,423-14,425, doi:10.1029/JB095iB09p14423.

Cohen, B. A. (2006), Quantifying the amount of impact ejecta at the MER landing sites and potential paleolakes in the southern Martian Highlands, Lunar Planet. Sci. [CD-ROM], XXXVII, Abstract 1043.

Gellert, R., et al. (2004), Chemistry of rocks and soils in Gusev Crater from the Alpha Particle X-Ray Spectrometer, Science, 305, 829-832, doi:10.1126/science.1099913.

Gellert, R., et al. (2006), Alpha Particle X-Ray Spectrometer (APXS): Results from Gusev Crater and calibration report, J. Geophys. Res., 111, E02S05, doi:10.1029/2005JE002555.

Goetz, W., et al. (2005), Indication of dryer periods on Mars from the chemistry and mineralogy of atmospheric dust, Nature, 436, 62-65, doi:10.1038/nature03807.

Hargraves, R. B., D. W. Collinson, R. E. Arvidson, and P. M. Cates (1979), Viking magnetic properties experiment: Extended mission results, J. Geophys. Res., 84, 8379-8384, doi:10.1029/JB084iB14p08379.

Haskin, L. A., et al. (2005), Water alteration of rocks and soils on Mars at the Spirit rover site in Gusev Crater, Nature, 436, 66-69, doi:10.1038/ nature03640.

Heinrich, C. A., D. Günther, A. Audétat, T. Ulrich, and R. Frischknecht (1999), Metal fractionation between magmatic brine and vapor, determined by microanalysis of fluid inclusions, Geology, 27, 755-758, doi:10.1130/0091-7613(1999)027<0755:MFBMBA>2.3.CO;2. 
Hurowitz, J. A., S. M. McLennan, H. Y. McSween Jr., P. A. de Souza Jr., and G. Klingelhöfer (2006a), Mixing relationships and the effects of secondary alteration in the Wishstone and Watchtower Classes of Husband Hill, Gusev Crater, Mars, J. Geophys. Res., 111, E12S14, doi:10.1029/2006JE002795.

Hurowitz, J. A., S. M. McLennan, N. J. Tosca, D. W. Ming, R. E. Arvidson, J. R. Michalski, C. Schröder, and S. W. Squyres (2006b), In situ and experimental evidence for acidic weathering of rocks and soils on Mars, J. Geophys. Res., 111, E02S19, doi:10.1029/2005JE002515.

Kurosawa, M., S. Shimano, S. Ishii, K. Shima, and T. Kato (2003), Quantitative trace element analysis of single fluid inclusions by proton-induced $\mathrm{X}$-ray emission (PIXE), applications to fluid inclusions in hydrothermal quartz, Geochim. Cosmochim. Acta, 67, 4337-4352, doi:10.1016/S00167037(03)00378-8

Longhi, J., E. Knittle, J. R. Holloway, and H. Wänke (1992), The bulk composition, mineralogy and internal structure of Mars, in Mars, edited by H. H. Kieffer et al., pp. 184-208, Univ. of Ariz. Press, Tucson.

Madsen, M. B., S. F. Hviid, H. P. Gunnlaugsson, J. M. Knudsen, W. Goetz, C. T. Pedersen, A. R. Dinesen, C. T. Morgensen, M. Olsen, and R. B. Hargraves (1999), The magnetic properties experiments on Mars Pathfinder, J. Geophys. Res., 104, 8761-8779, doi:10.1029/1998JE900006.

Madsen, M. B., et al. (2003), Magnetic properties experiments on the Mars Exploration Rover Mission, J. Geophys. Res., 108(E12), 8069 doi:10.1029/2002JE002029.

Madsen, M. B., et al. (2008), Overview of the magnetic properties experiments on the Mars Exploration Rovers, J. Geophys. Res., doi:10.1029/ 2008JE003098, in press.

McCoy, T. J., et al. (2008), Structure, stratigraphy, and origin of Husband Hill, Columbia Hills, Gusev Crater, Mars, J. Geophys. Res., 113, E06S03, doi:10.1029/2007JE003041.

McSween, H. Y., et al. (2004), Basaltic rocks analyzed by the Spirit Rover in Gusev Crater, Science, 305, 842-845, doi:10.1126/science.3050842.

McSween, H. Y., et al. (2006a), Characterization and petrologic interpretation of olivine-rich basalts at Gusev Crater, Mars, J. Geophys. Res., 111 , E02S10, doi:10.1029/2005JE002477.

McSween, H. Y., et al. (2006b), Alkaline volcanic rocks from the Columbia Hills, Gusev Crater, Mars, J. Geophys. Res., 111, E09S91, doi:10.1029/ 2006JE002698.

Ming, D. W., et al. (2006), Geochemical and mineralogical indicators for aqueous processes in the Columbia Hills of Gusev Crater, Mars, J. Geophys. Res., 111, E02S12, doi:10.1029/2005JE002560.

Ming, D. W., R. V. Morris, and B. C. Clark (2008), Aqueous alteration on Mars, in The Martian Surface: Composition, Mineralogy, and Physical Properties, edited by J. F. Bell III, chap. 23, pp. 519-540, Cambridge Univ. Press, Cambridge, U. K.

Mittlefehldt, D. W., R. Gellert, T. McCoy, H. Y. McSween, and R. Li (2006), Possible Ni-rich mafic-ultramafic magmatic sequence in the Columbia Hills: Evidence from the Spirit Rover, Lunar Planet. Sci. [CD-ROM], XXXVII, Abstract 1505.

Morris, R. V., D. C. Golden, J. F. Bell III, H. V. Lauer Jr., and J. B. Adams (1993), Pigmenting agents in Martian soils: Inferences from spectral, Mossbauer, and magnetic properties of nanophase and other iron oxides in Hawaiian palagonitic soil PN-9, Geochim. Cosmochim. Acta, 57, 4597-4609, doi:10.1016/0016-7037(93)90185-Y.

Morris, R. V., et al. (2000), Acid sulfate alteration products of a tholeiitic basalt: Implications for interpretation of Martian thermal emission spectra, Lunar Planet. Sci. [CD-ROM], XXXI, Abstract 2014

Morris, R. V., D. C. Golden, D. W. Ming, T. D. Shelfer, L. C. Jorgensen, J. F. Bell III, T. G. Graff, and S. A. Mertzman (2001), Phyllosilicatepoor palagonitic dust from Mauna Kea Volcano (Hawaii): A mineralogical and process analogue for magnetic Martian dust?, J. Geophys. Res., 106, 5057-5084, doi:10.1029/2000JE001328.

Morris, R. V., et al. (2006), Mössbauer mineralogy of rock, soil, and dust at Gusev Crater, Mars: Spirit's journey through weakly altered olivine basalt on the plains and pervasively altered basalt in the Columbia Hills, J. Geophys. Res., 111, E02S13, doi:10.1029/2005JE002584.

Morris, R. V., et al. (2008a), Iron mineralogy and aqueous alteration from Husband Hill through Home Plate at Gusev Crater, Mars: Results from the Mössbauer instrument on the Spirit Mars Exploration Rover, J. Geophys. Res., doi:10.1029/2008JE003201, in press.
Morris, R. V., G. A. McKay, D. G. Agresti, and L. Le (2008b), Mössbauer and electron microprobe studies of density separates of Martian Nakhlite MIL03346: Implications for interpretation of Mössbauer spectra acquired by the Mars Exploration Rovers, Lunar Planet. Sci. [CD-ROM], XXXIX, Abstract 2458.

Nesbitt, H. W., and R. E. Wilson (1992), Recent chemical weathering of basalts, Am. J. Sci., 292, 740-777.

Ruff, S. W., P. R. Christensen, D. L. Blaney, W. H. Farrand, J. R. Johnson, J. R. Michalski, J. E. Moersch, S. P. Wright, and S. W. Squyres (2006), The rocks of Gusev Crater as viewed by the Mini-TES instrument, J. Geophys. Res., 111, E12S18, doi:10.1029/2006JE002747.

Schmidt, M. E., et al. (2008), Hydrothermal origin of halogens at Home Plate, Gusev Crater, J. Geophys. Res., 113, E06S12, doi:10.1029/ 2007JE003027.

Squyres, S. W., et al. (2004), The Spirit Rover's Athena science investigation at Gusev Crater, Mars, Science, 305, 794-799, doi:10.1126 science. 3050794 .

Squyres, S. W., et al. (2006), Rocks of the Columbia Hills, J. Geophys. Res., 111, E02S11, doi:10.1029/2005JE002562.

Squyres, S. W., et al. (2007), Pyroclastic activity at Home Plate in Gusev Crater, Mars, Science, 316, 738-742, doi:10.1126/science.1139045.

Squyres, S. W., et al. (2008), Detection of silica-rich deposits on Mars, Science, 320, 1063-1067, doi:10.1126/science.1155429.

Tréguier, E., C. d'Uston, P. C. Pinet, G. Berger, M. J. Toplis, T. J. McCoy, R. Gellert, and J. Brückner (2008), Overview of Mars surface geochemical diversity through Alpha Particle X-Ray Spectrometer data multidimensional analysis: First attempt at modeling rock alteration, J. Geophys. Res., 113, E12S34, doi:10.1029/2007JE003010.

Wang, A., et al. (2006), Sulfate deposition in subsurface regolith in Gusev Crater, Mars, J. Geophys. Res., 111, E02S17, doi:10.1029/ 2005JE002513.

Wang, A., et al. (2008), Light-toned salty soils and coexisting Si-rich species discovered by the Mars Exploration Rover Spirit in Columbia Hills, J. Geophys. Res., doi:10.1029/2008JE003126, in press.

Yen, A. S., et al. (2008), Hydrothermal processes at Gusev Crater: An evaluation of Paso Robles Class soils, J. Geophys. Res., 113, E06S10, doi:10.1029/2007JE002978

R. E. Arvidson, Department of Earth and Planetary Sciences, Washington University, Campus Box 1169, 1 Brookings Drive, St. Louis, MO 63130 USA.

J. Brückner, Max-Planck-Institut für Chemie, Joh-Joachim Becher-Weg 27, D-55128 Mainz, Germany.

B. C. Clark, Space Science Institute, Boulder, CO 80301, USA.

B. A. Cohen, NASA Marshall Space Flight Center, Huntsville, AL 35812 , USA.

C. d'Uston and E. Tréguier, Centre d'Etude Spatiale des Rayonnements, OMP, Université Paul Sabatier, CNRS, 9 avenue du Colonel Roche, F-31028 Toulouse, France.

T. Economou, Enrico Fermi Institute, University of Chicago, 5640 South Ellis Avenue, Chicago, IL 60637, USA.

I. Fleischer and G. Klingelhöfer, Institut fur Anorganische und Analytische Chemie, Johannes Gutenberg Universität, Staudinger Weg 9, Mainz, D-55128, Germany.

R. Gellert, Department of Physics, University of Guelph, Guelph, ON N1G 2W1, Canada.

T. J. McCoy and M. E. Schmidt, Department of Mineral Sciences, Smithsonian Institution, Washington, DC 20560-0119, USA.

D. W. Ming, D. W. Mittlefehldt, R. V. Morris, and C. Schröder, NASA Johnson Space Center, Houston, TX 77058, USA. (douglas.w.ming@ nasa.gov)

S. W. Squyres, Department of Astronomy, Cornell University, Ithaca, NY 14853, USA.

A. S. Yen, Jet Propulsion Laboratory, California Institute of Technology, 4800 Oak Grove Drive, Pasadena, CA 91109, USA.

J. Zipfel, Forschungsinstitut und Naturmuseum Senckenberg, Senckenberganlage 25, D-60325 Frankfurt, Germany. 